\title{
THE CONCEPT OF A CORPORATION'S PURCHASE OF ITS OWN SHARES*
}

\author{
ROBERT L. PHILLIPS**
}

\section{INTRODUCTION}

The purpose of this paper is to examine in detail the concept of a corporation's purchase of its own shares. After reviewing the origin and development of the English and Canadian positions (a necessary element since a statement of the current law is necessary to determine what, if any, changes should be made) and the corresponding American position, the theoretical nature of the concept will be examined, followed by a discussion of the various uses for which a corporate share purchase power could be exercised, the potential abuse it could give rise to and the possible statutory safeguards that could be imposed to restrict such abuse.

\section{THE ORIGIN AND DEVELOPMENT OF THE ENGLISH AND CANADIAN POSITIONS}

\section{A. The Common Law}

Any study of the concept of a corporation purchasing its own shares must begin with an examination of the rule of English common law laid down by the House of Lords in Trevor v. Whitworth ${ }^{1}$ which bluntly prohibits such a transaction. ${ }^{2}$ In that case a corporation whose objects were to carry on a flannel manufacturing business and any other business or transaction which it might consider to be in any way conducive or auxiliary thereto, had in its articles a provision empowering it to utilize its funds to purchase its own shares. The corporation having gone into liquidation, a former shareholder's executors made a claim, in competition with the corporation's creditors, against the liquidator for the balance of the purchase price of the corporation's shares sold by him to the corporation prior to the liquidation. The purpose of the corporation's purchase of its own shares was to keep it a "family" enterprise.

The House of Lords ${ }^{3}$ held that a corporation's purchase of its own shares was completely illegal and unlawful and thus prohibited. ${ }^{4}$ They propounded three separate bases for their decision. It was pointed out

* The text of this paper is taken from a Report prepared for the Institute of Law Research and Reform as part of the Company Law project. The writer wishes to express his sincere appreciation for the guidance and assistance in the preparation of this paper provided by Professor Maurice J. Sychuk of the Faculty of Law, University of Alberta, Edmonton and Mr. George C. Field, Chairman of the Company Law Committee, Institute of Law Research and Reform. The writer's recommendations contained in the original Report are not included.

** B.Sc. (Chem. Eng.), LL.B. (Alta.), articling with the firm of Brownlee Fryett. Edmonton. Alta.

1 (1887) 12 A.C. 409 (House of Lords).

2 For an excellent discussion of the development of the concepts of share capitalization and limited liability of shareholders of corporations in English law leading up to the decision in Trevor v. Whitworth, see Levy. Purchase by an English Company of its Own Shares, (1930-31) 79 U. of Penn. L. Rev. 45 at 45.54.

3 Comprised of Lords Herschell, Watson, Fitzgerald and Macnaghten.

1. It is interesting to note that the prohibition in Trevor $v$. Whitworth was not founded entirely on the normal rule of ultra vires or lack of capacity, but on the quite different ground that the transaction was completely unlawful. This conclusion evinced the disapproval of the English court for it effectively nullified any future corporate actions which were not specifically authorized by statute or by Royal Charter. see Leblovic, Stock Purchase and Redemption Legislation in Ontario, (1968) 26 University of Toronto Faculty of Law Review 59 at 61 . 
that a purchase of its own shares by a corporation will be either of two things. It will be in effect a reduction of the corporation's capital stock, or else it will be a transaction whereby it is "trafficking in its own shares". That is to say, either the shares will be purchased for retainment to reduce the capital stock of the corporation or they will be for a time dormant as stock held by the corporation and later to be reissued. ${ }^{5}$ Thus, in the first place if the purchase was for the purpose of retaining and cancelling the said shares, it amounted to an unauthorized reduction of the corporation's share capital contrary to the provisions of the Companies Act. ${ }^{6}$ If, however, the action was precipitated for the purpose of resale of the shares by the corporation at some future date, there would be no reduction in capital since it would be recouped in the subsequent transaction. This led the House of Lords to the second basis of their decision; that is, that this would amount to an illegal trafficking by the corporation in its own securities. ${ }^{7}$ Finally, no matter what the intent of the purchase, any transaction which would tend to prejudice the position of the creditors and other shareholders of the corporation by diminishing the resources upon which these persons relied in case of a future winding-up or liquidation of the concern is unlawful. In this case, for example, more than one-fifth of the capital of the corporation had been withdrawn and it had increased its bank borrowings by a wholesale policy of share purchases over a period of years.

Leblovics $^{8}$ aptly states that this final reason was by far the motivating factor in the case. At the time, the principle of limited liability was still a relatively new concept in England ${ }^{9}$ and the ghosts of the infamous South Sea Bubble ${ }^{10}$ were still prominent in English jurisprudence. With this background one can readily understand the consternation of their Lordships with transactions which differed from those in the normal commercial field. An examination of the individual judgments in Trevor v. Whitworth and the later English and Canadian ${ }^{11}$ cases which followed or considered it discloses that the principle rationale for the rule prohibiting a corporation's purchase of its own shares is the protection of the creditors of the corporation who are entitled to rely on its paid-up capital as a source of funds to which they

3 This concept is discussed by Levy, Purchase by a Corporation of Its Own Stock, (1930-31) 15 Minnesota Law Review 1 at 27.

6 The Companies Act (U.K.), 1877.

7 Ballantine on Corporations (1946), at 603 states that the company's trafficking in its own shares was held to be ultra vires the company since its objects were limited to the manufacture of flannel and activities related thereto. Levy, supra, n. 2 at 51, 52 states that unless the purchase was for the retirement of the shares and the reduction of the capital, it would be for a resale and as such would constitute a trafficking in shares. If the memorandum of association did not authorize this as one of the objects of the company, the purchase was ultra vires, void and incapable of ratification. If the memorandum or articles did authorize such an object, the courts had to decide whether it was a legitimate one. When the issue first came squarely before the court in Hope v. The International Financial Society Ltd. (1877) $46 \mathrm{LJ}$. Ch. 200, the purchase was disallowed. After what seemed to have been a recession from the view in the Hope case, the House of Lords settled the English law on the subject in Trevor v. Whitworth.

In Trevor v. Whitworth, Lord Watson was troubled by the theoretical difficulty of having a company become a member of itself for that period of time that it held the shares prior to their resale. "It cannot be registered as a shareholder to the effect of becoming debtor to itself for calls, or of being placed on the list of contributories in its own liquidation. . . " (at 424). This concept prohibiting a company from becoming a shareholder of itself remains steadfast in our law even where shares are being purchased by the company pursuant to a statutory reduction of capital: In Re Companies Act, Section 61; In Re Medical Building Limited (1953) 9 W.W.R. 278 (Sask. Q.B.).

- Supra, n. 4 at 60 .

- The advantage of limited liability attached to banks on 1844 (7 \& 8 Vict. C. 110). Ten years later this privilege was conferred on all companies if their deeds so provided and their names were followed by the word "Limited" (1855) 18 \& 19 Vict., c. 133); see Levy, supra, n. 2 at 48.

$10 \mathrm{Id}$. at 47.

"The case most often cited a definitive authority for the proposition that Trevor v. Whitworth applies in Canada is Alberta Rolling Mills Co. v. Christie (1919) 58 S.C.L. 208 at 219. 
can look for payment. ${ }^{12}$ The capital of a corporation may be diminished or lost by expenditures made in the course of carrying on its business and this is a risk that both shareholders and creditors must bear, but it would clearly be prejudicial to creditors and their protection would be illusory if the corporation's assets could be freely distributed to its members. For example, Lord Herschell stated:13

What is the meaning of the distinction thus drawn between a company without limit on the liability of its members and a company where the liability is limited, but, in the latter case, to assure that those dealing with the company that the whole of the subscribed capital, unless diminished by expenditure upon the objects defined by the memorandum, shall remain available for the discharge of its liabilities? The capital may, no doubt, be diminished by expenditure upon and reasonably incidental to all of the objects specified. A part of it may be lost in carrying on the business operations authorized. Of this all persons trusting the company are aware, and take the risk. But I think they have a right to rely, and were intended by the legislature to have a right to rely, on the capital remaining undiminished by any expenditure outside these limits, or by the return of any part of it to the shareholders.

\section{Lord Macnaghten stated:14}

The third point is one of general importance. It raises the question whether it is competent for a company ... on the principle of limited liability, to purchase its own shares when it is authorized by its articles to do so. The consideration of that question, as it appears to me, necessarily involves the broader question whether it is competent for a limited company under any circumstances to invest any portion of its capital in the purchase of a share of its own capital stock, or to return any portion of its capital to any shareholder without following the course which Parliament has prescribed.

And further: ${ }^{15}$

. . they cannot draw on a fund in which others as well as themselves are interested. That, I think, is the law, and that is the good sense of the matter.

It is clear, therefore, that the thrust of the rule in Trevor $v$. Whitworth is that as a consequence of being able to operate under the privilege of limited liability, a corporation is under no obligation to return any of its paid-up capital to its shareholders during its existence, ${ }^{16}$ nor can it legally do so otherwise than as provided by the statute to which it owes its existence. ${ }^{17}$ To the creditors of a corporation, for whose benefit the

12 Although the rationale of the prohibitive rule, namely to prevent potential abuses, will be examined in greater detail later in the paper, a brief discussion is warranted so as to outline the development and application of the English (and Canadian) common law on this point.

13 (1887) 12 A.C. 409 at 415.

14 Id. at 432 .

1s Id. at 436 .

18 Campbell v. Prudential Trust Company Limited and Superintendent of Brokers [1944] 3 W.W.R. 456 (B.C.C.A.).

17 For Alberta companies, in accordance with the procedures and for the purposes set out in sections 38 to 41 of the Companies Act, R.S.A. 1970, c. 60.

Hornstein, Corporation Law and Practice, at 614 provides that the theory of contributed capital as a substitute for personal liability presupposes some assurance that the stated capital will remain available for legitimate business operations (subject, of course, to loss as a result of such operations). Levy, supra, $n$. 2 at 53 provides that the germ of the "trust fund" theory (as it is called in the United States) was here fully developed. Capital was thereafter regarded as a fund to be kept intact for creditors for the satisfaction of their claims. True, it may be necessary sometimes to reduce the capital, and the statute allows it, but "the stringent precautions to prevent the reduction of the capital of a limited company, without due notice and judicial sanction would be idle if the company might purchase its own shares wholesale, and so effect the desired result." (Per Lord Herschell at 416.)

The English courts have decided that the rule applicable to companies in which the members enjoy limited liability does not apply to "unlimited companies". As to such companies, there is no prohibition against the purchase of their own shares. Members may retire if the articles or memorandum so provide and be relieved from liability to creditors in the absence of fraud or any deliberate scheme to escape liability. In In Re Borough and Commercial Building Society [1893] 2 Ch. 242 the court held that the rule in Trevor v. Whitworth did not apply to such companies. There is nothing in the English Companies Act prohibiting an unlimited company from purchasing its own shares. Further, the nature of a company in which all its members are liable for all the company's debts does not require that any capital fund be kept intact: "By the very force of the terms, it is plain that in the case of an unlimited company the creditors know that there is 
rule was primarily established, the object or purpose for which a corporation has purchased its own shares makes no difference. The result to them is the same, namely that the shareholders receive back the monies subscribed and there passes into their pockets what before existed in the form of cash, or of buildings, machinery or other assets available to meet the creditors' demands. The rule applies even where the corporation is expressly empowered by its articles to purchase its own shares, such a provision being void"18 since "... neither the memorandum nor the articles can confer greater powers than the Act under which the company is incorporated."19 More importantly the prohibition has been held to apply regardless of whether the corporation is solvent at the time of its purchase of its own shares, with the result that creditors may not be prejudiced, on the basis that where a statute “. . . sanctions the doing of a thing under certain conditions, it must be taken that the thing is prohibited unless the prescribed conditions and restrictions are observed." 20

In addition to the protection of creditors, Lord Macnaghten provided a subsidiary reason for the prohibition against a corporation purchasing its own shares in his answer to the argument that the power to purchase shares might be validly exercised as an incident of domestic management to buy out shareholders whose continuance was undesirable:21

Is it possible to suggest anything more dangerous to the welfare of companies and to the security of their creditors than such a doctrine? Who are the shareholders whose continuance in a company the company or its executive consider undesirable? Why, shareholders who quarrel with the policy of the board, and wish to turn the directors out; shareholders who ask questions which it may not be convenient to answer; shareholders who want information which the directors think it prudent to withhold. Can it be contented that when the policy of directors is assailed, they may spend the capital of the company in keeping themselves in power, or in purchasing the retirement of inquisitive and troublesome critics?

Thus, the rule in Trevor v. Whitworth also provides a basis for the protection of the shareholders of a corporation, especially those in a minority position, since the prohibition of a corporation's purchase of its own shares prevents the directors from authorizing a purchase in order to maintain control, remove a troublesome shareholder, restrict membership in the corporation, ${ }^{22}$ or otherwise reduce capital by issuing

no fixed capital, and, therefore they have no right to complain, if I may use the term, of a reduction of that which has never been fixed in any way." (At 255.)

is Trevor v. Whitworth, supra; Re Fish and Game League (Regina) (1967) 63 D.L.R. (2d) 47 (Sask. Q.B.).

19 Per Clarry M.C., in In Re The Walbridge Grain Company Ltd. [1918] 2 W.W.R. 886 (Alta. S.C.). affirmed [1918] 2 W.W.R. 890 (Alta. S.C.A.D.). Article 6 of Table A of the Alberta Companies Act provides: " 6 . No part of the funds of the Company shall be employed in the purchase of, or in loans upon the security of, the Company's shares."

so Trevor v. Whitworth (1887) 12 A.C. 409 at 437 (per Lord Macnaghten). It is interesting, however, to note the apparent reluctance in following the rule in such a situation as evidenced by the statement of Hyndman $J$. in In Re The Walbridge Grain Company Ltd., supra, n. 19 at 892: "As the parties affected were acting in the utmost good faith and atl the debts of the company were fully paid it is with some reluctance that I dismiss the appeal!"

It is also interesting to note that in England an invalid purchase by a company of its own shares apparently can be cured, in appropriate circumstances, by a subsequent reduction of capital. In In Re Liverpool Cotton Association Lld. (1963) 107 Sol. Jo. 195 (Ch. D.), the company was incorporated in 1880 with a capital of 600 £100 shares, $\mathbf{2 0}$ being paid up on each share. The memorandum gave the company the power to purchase its own shares and on various dates the company bought a total of thirty-nine shares. This situation continued quite happily until the occasion of a take-over bid. In an effort to remedy the situation the company passed a resolution for the reduction of capital by cancelling the thirty-nine shares. On application to the court for confirmation of the reduction, it was held that section 66 of the English Companies Act gave wide powers of sanctioning reductions of capital and in view of the circumstances the reduction was sanctioned even though the actual purchase of the shares by the company was ultre vires.

21 Trevor v. Whitworth (1887) 12 A.C. 409 at 435 . This objection, that by entrusting companies with the power to purchase their own shares then it might be employed to buy out undesirable shareholders, was first raised by Jessel M.R. in Re Dronficld Silkstone Coal Co. (1880) 17 Ch. D. 76.

22 Re Fish and Game League (Regina) (1967) 63 D.L.R. (2d) 471 (Sask. Q.B.). 
fully paid-up shares at a discount to certain shareholders, ${ }^{23}$ or the release of certain shareholders from their liability for uncalled capital.

It was early recognized, however, that the rigid application of this common law principle might be unduly strict ${ }^{24}$ and thus over the years the common law has, apart from statutory reform, allowed certain classes of transactions wherein the result was that a corporation was able to acquire its own shares. The prohibition against a corporation purchasing its own shares is primarily based on the prejudice to creditors that arises because such a purchase involves the paying out of corporate assets (in the form of cash or otherwise) to its members. Thus, where a corporation receives its own fully paid-up shares in a transaction which does not require it to pay out any assets to the relinquishing shareholder, the transaction will not be invalid since it does not involve an unauthorized reduction of share capital.

For example, when a shareholder owed the corporation a debt, either from a commercial transaction, or through incomplete payment of the share price from primary distribution, the rule in Trevor $\mathrm{v}$. Whitworth was held not to apply so as to permit the creditor corporation to acquire the shares in lieu of the debt. ${ }^{25}$ The rationale put forward by the courts was that the corporation was not reducing its capital for, in fact, it was eliminating a liability form its books, nor was it prejudicing its creditors since this type of transaction in reality made no substantial alteration to the capital structure. ${ }^{26}$

Similarly, an exchange of fully paid-up shares for others of a like par value $^{27}$ or a surrender of fully paid-up shares does not constitute a violation of the rule. In Zwicker v. Stanbury, Cartwright J. (as he then was) stated:28

Such surrender is in no sense a purchase by the company of its own shares as it involves neither payment by the company nor (the shares being fully paid up) the release by the company of any liability to it. No reduction in capital is brought about as the company parts with nothing and its authorized capital will remain unaltered, although the number of issued shares will be reduced and the number of unissued shares will be correspondingly increased.

A shareholder may bequeath ${ }^{29}$ or transfer ${ }^{30}$ fully paid-up shares to the corporation or to a trustee for the benefit of the corporation, provided that no consideration for such bequeath or transfer passes from the corporation.

A surrender or forfeiture of partly-paid shares presents a different

2.1 Oregum Gold Mining Co. of India Ltd. v. Roper [1892] A.C. 125 (H.L.). The issuance of full paid-up shares at a discount is prohibited in Alberta under the Companies Act, R.S.A. 1970, c. 60, s. 114(2).

24 Gower, The Principles of Modern Company Law, (3d ed. 1969) at 111.

2. In Re Denver Hotel Co. Ltd. [1893] 1 Ch. 498.

26 Levy, supra, n. 5 at 37 provides that a situation in which it is justifiable for a corporation to become the owner of its own shares, is in the settlement of an otherwise uncollectable debt from one of its shareholders. The justification is the necessity of saving loss. Likewise in compromising a claim of the corporation against one of its members, the merits of which are in dispute, the directors should be permitted to accept shares. Here, too, the device would be resorted to in order to save the corporation money and trouble. Of course, the limitation on the exercise of the power in these cases is that the directors use honest and reasonable judgment that the debt is otherwise uncollectable or that the disputed claim merits this sort of compromise.

2: Rowell v. John Rowell \& Sons Ltd. [1912] 2 Ch. 609.

$2 k$ [1954] 1 D.L.R. 207 (S.C.C.) at 270-271.

2y Re Castiglione's Will Trusts [1958] Ch. 549.

30 Kirby v. Wilkins [1929] 2 Ch. 444; Re Northern Canadian Mortgage Co. Ltd.; Moore v. Northwood (1960) 22 D.L.R. (2d) 757 (B.C.S.C.). Hornstein, supra, n. 17 at 613 provides that the fact that there are apparently no limitations upon a corporation's acquiring its own shares by gift or bequest where no money is paid, led to the development of the unsavory promotional practice of gifts to the corporation ("donated stock"), so often a prelude to frauds upon the public investor. 
situation since presumably the result of such surrender or forfeiture is to release the shareholder from any further liability with respect to the shares, thereby constituting a reduction of capital. Their Lordships in Trevor v. Whitworth did not make a distinction as to whether the shares surrendered or forfeited were fully paid-up or not in stating that any forfeiture or surrender is not prohibited since it did not require the corporation to pay out any assets in return for the shares. ${ }^{31}$ Gower $^{32}$ explains that Trevor v. Whitworth stands for the proposition that a company may accept a surrender of partly-paid shares to avoid the formalities of forfeiture. ${ }^{33}$ Gore-Browne ${ }^{34}$ provides that court confirmation of a reduction of capital under section 66 of the English Companies Act, 1948 is not required where a corporation has an express power in its articles to accept forfeited shares and to either cancel or reissue them. ${ }^{35}$ The rationale for such provisions is based on the premise that creditors who grant credit to a corporation are not prejudiced if they are cognizant of the fact that a portion of the issued capital is not fully paid-up and the corporation has power in its articles to accept a forfeiture of shares not fully paid-up-or, alternatively, that the creditors are only entitled to rely on the paid-up capital of the corporation as a source to look to for payment of their claims. ${ }^{36}$

The rule in Trevor v. Whitworth has also been held not to apply where shares issued by a corporation in return for an asset are returned and cancelled where the asset proves to be worthless to the corporation and the transferor is willing to take it back. ${ }^{37}$ Such a proposition was again based on the principle that the transaction whereby the corporation received its own shares did not involve the paying out of any of its assets since the asset re-transferred was worthless to the corporation. The proposition espoused by Macdonald J.A., however, presents an interesting restriction of the application of the common law rule: ${ }^{38}$

If, on the other hand, it is insisted that some value must be given to this asset, and if to the extent of that value the capital was incidentally diminished, it still does not follow that the transaction is void [under the rule in Trevor v. Whitworth]. Each case must be decided on its own facts and I apprehend that the dimunition in capital must not be fanciful or theoretical, but actual and substantial, before the transaction can be successfully attacked.

The prohibition against a corporation purchasing its own shares has also been held, in Canada, not to apply to the provision of financial assistance by the corporation for the purchase by a third party of its own shares. ${ }^{39}$ In Mt. View Charolais Ranch Ltd; Lynch v. Haverland,

"See for example, (1887) 12 A.C. 409 at $417-418$ (per Lord Herschell).

a. Supra, n. 24 at 115.

*3 This is substantiated in Bellerby v. Rowland and Marwood's S.S. Co. Ltd. [1902] 2 Ch. 14. Doubt as to the propriety of an unqualified right to accept the surrender of partly.paid shares was expressed by Cartwright $J$. (as he was then), in Zwicker v. Stanbury [1954] 1 D.L.R. 251 at 271 . As Levy, supra, n. 5 at 36, provides, if a surrender were accepted in a situation where the shares were not fully paid-up and the balance due was collectable, creditors and shareholders alike could object that this was in effect a modified purchase, and that the cancellation of an enforceable claim against the subscriber was a parting with valuable corporate assets.

it Gore-Browne on Companies, edited by A. J. Boyle, (42d ed. 1972) at 345.

3s Such express provisions exist in the Alberta Companies Act. R.S.A. 1970, c. 70, Table A, art. 21-26.

35 Paragraph $36(1)$ (c) of the Alberta Companies Act effectively provides that a company can only accept a surrender of fully paid-up shares by way of gift if its articles so provide. The problems raised by the concept of partly-paid shares are beyond the scope of theis paper and a discussion of such would bear little relevance in light of the Committee's decision to remove the concept from Alberta company law.

37 British Columbia Red Cedar Shingle Co. Ltd. v. Stolze Manufacturing Co. Ltd. [1932] 1 W.W.R. I64 (B.C.C.A.).

3* Id. at 172-173. See also, on a similar point, the earlier case of Wheeler and Wilson Manufacturing Co. (1885) 6 O.R. 421.

${ }^{34}$ Hughes v. The Northern Electric and Manufacturing Company (1914) 50 S.C.R. 626: Mt. View Charolais Ranch Ltd.; Lynch v. Haverland [1974] 2 W.W.R. 289 (Alta. S.C.A.D.) but contra. Murray and Murray v. C. 
Prowse J.A., after reviewing the individual judgments in Trevor v. Whitworth, stated:40

It will be noted that in the above judgments a distinction was drawn between the impairment of the capital structure of a company that flows from a purchase of its own shares and the impairment of the financial position of a company when it enters into a transaction reasonably incidental to its objects which turns out unfavourably from the company's point of view. In other words the basic objection to a purchase by a company of its own shares was that it effected a reduction of capital in a manner not authorized by the Companies Act.

I have considered a number of cases in which Trevor v. Whitworth has been considered as applied and they dealt generally with the extension of the principle therein enunciated to cases dealing with forfeiture of shares other than in accordance with the statutory requirements, selling of shares at a discount and like transactions that effected a reduction of capital of the company.

Professor Berner ${ }^{41}$ suggests that there has been an increasing tendency of the courts to restrict the effect of the well-established rule in Trevor v. Whitworth and cites the decision in Mt. View Charolais Ranch Ltd.; Lynch v. Haverland as an example.

The Jenkins Committee provided:42

We do not think that the practice whereby a company provides financial assistance for the acquisition of its own shares necessarily offends against the rule that a limited company may not buy its own shares. . . . The reason why a limited company may not buy its own shares is that in doing so it would part outright with the consideration for the purchase and thereby reduce its capital. A company which lends money to a person to buy its shares simply changes the form of its assets and if the borrower is able to repay the loan the company's capital remains intact.

They accordingly suggested that the provision of financial assistance should be permissible if the transaction was approved by a special resolution of the corporation and a declaration of its solvency after the transaction made and filed by the directors. It was pointed out that these requirements would effectively prevent the possible prejudice of minority shareholders and creditors. ${ }^{43}$ Gower, ${ }^{44}$ on the other hand, submits that the provision by a corporation of financial assistance for the purchase or subscription of its shares is objectionable. He states that the common practice of a take-over bidder to buy the shares in a corporation with large liquid assets and then using those assets to recoup the bridging loan he raised to initially pay for the shares can be prejudicial to both creditors and minority shareholders. Although approving of the safeguards recommended by the Jenkins Committee, he notes that as yet they have not been implemented.

It is clear, therefore, that although there has developed a number of minor exceptions to the prohibition against a corporation's acquisition of its own shares, all of which were dependent upon the fact that in no way was the corporation, its shareholders, or its creditors prejudiced by such actions, there has been very little basic deviation at common law from

W. Boon \& Company Ltd. [1974] 2 W.W.R. 620 (Alta. D.C.). Section 14 of the Alberta Companies Act, however, prohibits a public company from providing such assistance. In England. 8 . 54 of the Companies Act, 1948 purports to prohibit all companies from providing such financial assistance. It has been criticized. however, as having prejudiced the innocent without deterring the guilty. Section 67 of the Australian Companies Act provides a similar prohibition; see Barrett, Financial Assistance and Share Acquisitions, (1974) 48 Australian L.J. 6.

41" [1974] 2 W.W.R. 289 (Alta. S.C.A.D.) at 296-297.

" Berner, Annual Survey of Canadian Law: Corporation Law, (1975) 7 Ottawa L. Rev. 153 at 161.

Iz (1962), Cmnd. 1749, para. 173.

4. Id. at paras. 177.186.

4t Supra, n. 24 at 113. 
the rule laid down in Trevor v. Whitworth and its basic principle has remained intact. ${ }^{45}$

\section{B. Statutory Modification of the Common Law}

With the growth of the common law exceptions, however, it was soon recognized that to a certain extent the prohibition in Trevor v. Whitworth was restrictive upon corporate activities. Thus, there have emerged statutory modifications which, according to some authors, ${ }^{46}$ evidence a gradual movement away from the strictness of the rule and show an increasing realization that the corporation, like the individual, requires flexibility in its commercial transactions if it is to be able to compete as a viable entity in the business market.

In Alberta, the strict rule in Trevor v. Whitworth has been relaxed to some extent by the Companies Act.

\section{Reduction of Share Capital}

The inability of a corporation to purchase its own shares was seen to be impractical in certain circumstances. In particular, ${ }^{47}$ if a corporation had consistently made losses so that its net worth was hopelessly below the figure fixed by its capital, little purpose was served by maintaining the capital yardstick at its original figure-a figure no longer represented by assets to which creditors could look for payment. This was, however, very different from a repayment of the corporation's assets to its members in return for their shares, but even the latter might sometimes be for a legitimate business reason. If the corporation curtailed its activities so that its net assets were greater than it needed or could profitably employ, then, provided creditors were provided for, it was pointless to refuse to allow it to make a repayment to its members in reduction of the issued capital. Thus, the strict application of the common law prohibition has been modified by the Alberta Companies $\mathrm{Act}^{48}$ so as to allow a corporation to reduce its issued capital, subject to certain safeguards and to the consent of the court, for the following purposes: 49

38. (1) A company having a share capital by special resolution confirmed by an order of the court,

(b) may alter its memorandum so as to reduce its share capital in any way, and without prejudice to the generality of the foregoing power may modify or alter its memorandum 80 as to

(i) extinguish or reduce the liability on any of its shares in respect of share capital not paid up, or

(ii) either with or without extinguishing or reducing liability on any of its shares, cancel any paid-up share capital that is lost or unrepresented by ávailable assets, or

(iii) either with or without extinguishing or reducing liability on any of its shares, pay off any paid-up share capital that is in excess of the wants of the company.

The introduction of such a procedure has been suggested as evidencing a more progressive attitude which has become more

\footnotetext{
is Getz, Some Aspects of Corporate Share Repurchases, (1974) 9 U.B.C. L. Rev. 9.

'6 For example. Lebrovic, supra, n. 4 at 61; Gower, supra, n. 24 at 114.

7. Gower, supra, n. 24 at 111-112.

4s Sections 38 to 41 .

19 Para. 38(1)(b).
} 
prevalent today and shows the direction which newer legislation is taking in recognizing the need for more modern business techniques. ${ }^{50}$

\section{Redeemable Shares}

As early as 1929 in England, Parliament recognized the need for equity holdings which had certain advantages over the basic common shares so as to attract more investors into the corporate area. As a result, it created what is now the redeemable preference share. This concept was soon adopted into Alberta corporation law and is considered to represent perhaps the most notable and probably most significant statutory exception to the common law prohibition..$^{51}$ Section $69(1)$ of the Alberta Companies Act allows a corporation to issue preferred shares expressly created as redeemable. The dangers of redemption, in effect a purchase by a corporation of its own shares, are lessened since their value is unlikely to fluctuate much and they normally do not carry voting rights. Section 70 provides for the requirements of their redemption and ensures that the capital yardstick is not reduced. They can be redeemed when fully paid ${ }^{52}$ and only out of the proceeds of a fresh issue of shares made for the purposes of the redemption, in which case the capital of the new shares will replace the capital of those redeemed, or out of profits as would otherwise be available for dividend. ${ }^{53}$ In the latter event an amount equivalent to the nominal amount of the shares redeemed ${ }^{4}$ must be transferred to thr "capital redemption reserve fund" and this has to be treated as if it were paid-up capital of the corporation. ${ }^{55}$ Hence, although the shares redeemed disappear, the paid-up capital which they represent is retained for accounting purposes and there is no reduction of the capital yardstick.

In discussing a similar provision in the English Companies Act, Gower states: $: 5$

The section is a recognition that it is possible to allow companies to buy their own shares without opening the door to abuse. The Jenkins Committee considered whether, as in the U.S.A., there should be a general power for companies to buy their own shares. Although they recognized that the needful safeguards could be provided and would not be unduly complicated, they rejected this idea largely because there was no demand for it. This illustration of the conservatism of the English legal and commercial world is regrettable, since such a power would undoubtedly be useful to private companies and to all companies wishing to introduce employee shareownership schemes and would enable unit trusts to operate as companies instead of through the more complicated medium of a trust.

\section{Mutual Fund Shares}

Section 71 provides for another express exception in the case of "mutual fund shares". These are shares issued by a corporation whose only undertaking is the business of investing the funds of the corporation. ${ }^{57}$ At the demand of the holder of such shares, this type of corporation shall accept a surrender of all of the shares or fractions or parts thereof as are fully paid and the price to be paid therefor may be paid out of the corporation's assets, including its capital.58 Upon

so Leblovic, supra, n. 4 at 63.

st Jacobucci, et al., Selected Topics in Canadian Company Law Reform, (1975) at 113.

$\therefore$ Section $79(2)$.

s:i Section 70(1).

st Any premium payable on redemption must be provided out of profits or a share premium account.

s. Section 70(3).

so Supra, n. 24 at 114, from where the text of the explanation of the Alberta section was adopted.

si Section 71(2).

so Section 71(4). 
surrender, such shares are deemed to be no longer outstanding and cannot be reissued by the corporation. ${ }^{59}$

\section{Abrogation of the Common Law Rule B $^{6}$}

Recently, three separate pieces of Canadian legislation have completely abrogated the common law prohibition and conferred on corporations a general power to purchase their own shares. ${ }^{61}$ These provisions follow a precedent which, in one form or another, has long been established in many jurisdictions in the United States. ${ }^{62}$ It first surfaced in Canada in the draft uniform corporation statutes published by the Conference of Commissioners on Uniformity of Legislation in Canada in $1960,{ }^{63}$ but only found its way into legislation for the first time in the Ontario Business Corporation Act, 1970. With the single exception of Ghana, ${ }^{64}$ however, it has not found favour outside continental North America in any country whose corporation law heritage is basically English. It was deliberately rejected by the Jenkins Committee in Great Britain in 1962,65 and by the South African Company Law Commission in 1972.66

\section{THE ORIGIN AND DEVELOPMENT OF THE AMERICAN POSITION}

\section{A. The Common Law67}

The question when, if at all, a corporation may lawfully purchase its own shares is one on which American authority developed very slowly. In the early stages of their law, American judges and lawyers got their notions about corporations from English cases and treatises. But the law of England in the early part of the last century relating to business corporations was not very helpful, especially for the solution of the problems presented by the dynamic organization which the American corporation was becoming. On the problem of the purchase by a corporation of its own shares, the English cases were confused and confusing until near the close of the century (when Trevor v. Whitworth was decided by the House of Lords), and were further complicated by a failure to differentiate clearly between the principles applicable to jointstock companies without limited liability of its members, and corporations proper. Thus, when the issue came before the American courts for the first time, there was little, if any, reliance on English precedent and the judges and lawyers were forced to unravel it on considerations of policy and logic. It was not surprising, therefore, that from an early

34 Section $71(3)$.

(1) See generally, Getz, supra, n. 45 at 9-10.

st Ontario Business Corporations Act, R.S.O. 1970, c. 53, s. 39; British Columbia Companies Act, S.B.C. 1973, c. 18, s. 256(b); Canada Business Corporations Act, S.C. 1974-75, c. 33, s. 32. Recently, the Law Reform Division of the Department of Justice of New Brunswick recommended the abrogation of the common law rule as well: Report on Company Law (1975) at 86-92.

8: The American position will be discussed in the text section of this paper.

*3 For professional reaction to these proposals, see [1966] Can. Bar Ass'n. Papers 57 at 110: "The reaction of the Bar to the modification of the principle against purchase by a company of its common shares is uniform, emphatic and negative."

Bt Final Report of the [Gower] Commission of Enquiry into the Company Law of Ghana (1961), s. 59.

os (1962) Cmnd. 1749, paras. 167.169.

66 See generally. Benade, The Report of South African Companies Act Commission, (1971) 4 Comp. and Int'l. LJ. of S. Africa 85. Nussbaum, Acquisition by a Corporation of its Own Stock, (1935) 35 Colum. L. Rev. 971, discusses some of the German development in this area of the law and its rejection of the American view.

o7 See generally. Dodd, Purchase and Redemption by a Corporation of its Own Shares: The Substantive Law. (1940-41) 89 U. of Penn. L. Rev. 697 at 698-702; Levy, supra, n. 5 at 11-16. The basic text for this section of the paper has been drawn principally from these two sources. 
date there was a lack of unanimity as to the power to make such purchases.

\section{Professor Dodd aptly summarizes the judicial development of the American common law rule:68}

The earliest expression of judicial opinion on the subject seems to be the dictum in the case of Ex parte Holmes, ${ }^{69}$ decided by the Supreme Court of New York in 1826, to the effect that a corporation may take its own shares in payment of a debt due to it. This case was followed by some inconclusive remarks on the subject by the Vice-Chancellor some five years later, ${ }^{70}$ and by a vigorously expressed disapproval of an ordinary agreement to purchase by the same Supreme Court in Barton v. Port Jackson, ${ }^{71}$ decided in 1854. Four years later the New York tide turned as a result of a statement in an opinion by Selden J. in the New York Court of Appeals that he was not aware of any common law principle which forbade a corporation to buy its own shares. This statement subsequently came to be regarded, both in New York and elsewhere, as aligning that important jurisdiction with the view that, subject to some ill-defined limitations, the purchase by a corporation of its own shares is a legitimate corporate act. ${ }^{72}$

During the period in which the New York courts were handing down these opinions, the question was also being dealt with to a slight extent in a number of other jurisdictions. The most significant of these early cases are: Hartridge v. Rockwell, ${ }^{73}$ in which, in holding that shares purchased by a corporation could be resold, the court expressed the opinion that the purchase was legally unobjectionable; Percy v. Millaudon, ${ }^{74}$ in which directors of a bank who had sold their shares to it were compelled to refund the purchase price at suit of a shareholder, the court saying that the purchase reduced the capital and in consequence injured the creditors, the shareholders and the general public; and Taylor v. Miami Exporting Co., ${ }^{75}$ in which the court, in a case involving merely the taking of shares in payment of a debt, used broad language in support of the existence of a general right to purchase.76

A few favourable ${ }^{77}$ and unfavourable dicta ${ }^{78}$ uttered during the next forty years were finally followed by what seems to have been the first square decision in favor of the power to purchase, that of the Massachusetts court in Dupee v. Boston Water Power Co ${ }^{79}$ In that case the court dismissed a bill for an injunction brought by a shareholder against his company, which was engaged in filling and grading tide-flowed lands in order to sell them in lots, and which had offered to accept its own shares in payment of one-half of the purchase price of each lot of land sold. During the same decade, the courts of Illinois $^{80}$ and Iowa ${ }^{81}$ took the position that an agreement by a corporation to purchase its own shares was valid and binding on it. On the other hand, the courts of New Hampshire ${ }^{82}$ and Kansas ${ }^{83}$ held that such purchases were rescindable by the corporation, so that the numerical weight of the decisions during the ten-year period was only slightly in favor of the laxer view.

The period from 1880 to 1890 brought about a temporary turning of the tide with a decision by the Ohio court ${ }^{84}$ limiting the scope of its previous decision to cases in which the shares were taken in payment of a debt; one by the Illinois court ${ }^{85}$ holding that its earlier decision in favor of the power to purchase did not mean that the

nis Supra, n. 67 at 698-702.

4 (1826) 5 Cow. 426 at 434.5 (N.Y.S.C.).

iu Jerplank v. Mercantile Ins. Co. (1831) 1 Edw. Ch. 84 at 94 (N.Y.).

i1 (1854) 17 Barb. 397 (N.Y.S.C.).

i2 City Bank of Columbia v. Bruce \& Fox (1858) 17 N.Y. 507 at 51.

73 (1828) R. M. Charlton 260 (Ga. Sup. Ct.).

74 (1832) 3 La. 568.

73 (1833) 6 Ohio 176.

i6 See also Williams v. Savage Mfg. Co. (1851) 3 Md. Ch. 418.

it American Railway.Frog Co. v. Haven (1869) 101 Mass. 398 at 402 ; Lelano v. Hayden (1869) 102 Mass. 542 at 551.

7* Coleman v. Columbia Oil Co. (1865) 51 Pac. 74.

79 (1873) 114 Mass. 37.

* Chicago Pekin \& South Western R.R. v. Marseilles (1876) 84 Ill. 145.

Bi Iowa Lumber Co. v. Foster (1879) 49 Iowa 25.

s. Currier v. Slate Co. (1875) 56 N.H. 262

8.3 German Savings Bank v. Wolfekuhler (1877) 19 Kan. 60.

w Coppin v. Greenlees \& Ransome Co. (1882) 38 Ohio St. 275.

ns Clapp v. Peterson (1882) 104 III. 26. 
purchase could not be impeached by a creditor where the payment was made out of capital and the corporation later became insolvent; and one by the Connecticut court $^{86}$ holding that purchases made by a corporation whose capital was impaired could be rescinded by a subsequently-appointed receiver. . . .

Although one who studied the American law of fifty years ago might have hesitated to predict that the full rigor of the English view, according to which such purchases were ultra vires, would generally prevail in this country, he might reasonably have hazarded the opinion that few, if any, American courts would sustain such purchases against attack by unpaid creditors, at least where the purchase involved the depletion of corporate capital. Nevertheless, the subsequent development of American case law in the majority of jurisdictions has not been very favorable to creditors. It is true that, since 1890 , several additional jurisdictions have with little or no aid from statutes, denied or greatly restricted a corporation's power to purchase its own shares. ${ }^{86}$ But during the period between 1890 and the beginning of the movement for modernization of corporation statutes which became active about the year 1927, a substantially larger number of courts joined the ranks of those who saw nothing improper in a corporation's use of its capital for the purchase of its own shares.87

A number of factors contributed to this result. The prestige of those American courts which had, as early as 1890, by language or decision given their approval to such purchases, at least in cases in which the rights of creditors were not directly at issue, was somewhat greater than that of the courts which had adopted a stricter view. Furthermore, much of the litigation, both before and after that date, involved the validity not of the purchase but of the reissue of the purchased shares, and casual statements in opinions dealing eith the latter question to the effect that the original purchase was valid were sometimes taken at their face value without regard to the context in which they were found. Finally, and perhaps most important, it continued to be true for a good many years after 1890 that even the cases in which the validity of the purchase was directly at issue were, with rare exceptions, cases to which neither creditors nor representatives of creditors were parties.

When such cases did arise, even the courts which had sustained the power to make purchases out of capital did not completely ignore the rights of creditors. Persons whose shares the corporation had promised to purchase were generally denied the right to enforce that promise or security given for it in competition with its other creditors if the corporation was insolvent when the promise was made or became so prior to performance.88 One or two courts, however, permitted the shareholder even then to compete with subsequent creditors who had notice of the agreement at the time when they extended credit. 89

In several cases, the further step was taken of holding that a payment made by an insolvent corporation as the purchase price of its own shares may be recovered by or for creditors..$^{90}$

The majority common law rule is properly stated by Olsen, ${ }^{91}$ viz., “. . a private corporation may purchase its own stock if the transaction is fair and in good faith; if the corporation is not insolvent, or in the process of dissolution; and if the rights of its creditors are in no way affected thereby." The cases under the majority rule permitting this power in corporations fall into several classes, so far as the reasons given for the result. First, there were the courts which found no express prohibition against the practice in the statutes or the corporation's charter, and seeing nothing inherently vicious in such purchases, decided that the power existed.92 Then there were others which, although failing to find an express grant of power to purchase its own shares,

NH Crandall v. Lincoln (1884) 52 Conn. 73.

n: Vail v. Hamilton (1881) 85 N.Y. 453 at 457, containing a dictum in favour of a power to purchase.

wN Bogus v. Fleming (1933) 66 F. (2d) 859; Coleman v. Tepel (1916) 230 F. 63 (in which the corporation gave a bond and mortgage for its shares and was immediately rendered insolvent thereby); Commercial National Bank v. Burch (1892) 141 Ill. 519.

s9 First Trust Co. v. Mlinois Central Railway (1919) 256 Fed. 830.

90 Fitzpatrick v. McGregor (1909) 133 Ga. 332.

91 Olsen, Power of a Corporation to Repurchase its Stock, (1940-43) Vol. 1.4 Montana Law Review 64. The American common law rule and its application is also considered by Blackstock, $A$ Corporation's Power to Purchase its Own Shares and Some Related Problems, (1934-35) 13 Texas Law Review 442.

y2 Dupee v. Boston Water Power Co., supra, n. 79; Hartridge v. Rockwell, supra, n. 73. 
thought the power was incidental and necessary to accomplish the main objects for which the corporation was formed.93 Another line of cases found direct authorization in the usual power given corporations in the statutes or the corporation's charter to purchase, sell and hold property, both real and personal. It had long since been decided that shares of stock, including its own, were personalty, ${ }^{94}$ and the definition was felt to have compelling force. ${ }^{95}$

It was admitted, however, that a corporation's power to purchase its own shares was circumscribed by the usual safeguards against fraud and breach of the fiduciary duties of the directors and majority shareholders, and in this way other parties were thought to be protected. ${ }^{96}$ A purchase was also invalid if it did in fact defraud or prejudice creditors or other shareholders, even though made in the most perfect good faith. ${ }^{97}$ These rules were considered, however, to be 80 vague as to offer little practical protection. ${ }^{98}$ Many jurisdictions developed the rule that a corporation's purchase of its own shares was valid only if made out of surplus. Others, however, were even more liberal in providing that if a corporation was solvent it could purchase its own shares and such purchases were not restricted to surplus. The mere fact that the capital of the corporation was or might have been impaired by such purchase did not invalidate it, provided only that it was done in good faith and without prejudice to creditors or shareholders.99 The statutory regulations as to the reduction of capital were held not to impliedly forbid such purchases. The liberal view has been criticized as being unsafe as to creditors and shareholders generally and unduly lax as to the powers of the management. ${ }^{100}$

Fairly contemporaneously with the development of the majority view permitting a corporation to purchase its own stock, a contrary rule took root in a minority of states prohibiting such practices. There, too, the reasons given for the result varied. ${ }^{101}$ There were those courts which regarded a corporation as a legal personality of limited powers, operating under a state agent, capable of performing only such acts as were expressly authorized by the state. ${ }^{102}$ Failing to find any definite grant of power to buy its own stock, either in the statutes or the corporation's charter, the purchase was held to be invalid. ${ }^{103}$ It was also decided that the enumeration of the powers which corporations could

93 Thus, in Dupee v. Boston Water Power Co., supra, n. 79, it was held that a corporation chartered with the power to purchase and operate water power plants could, when its water power privileges were no longer profitable, lawfully sell its sites and receive its own stock in payment. See also Williams v. The Savage Mfg. Co., supra, n. 76.

94 Bligh v. Brent (1837) 2 Y. \& C. Ex. 268.

95 Berger, v. U.S. Steel Corp. (1902) 53 Atl. 68. Levy, supra, n. 2 at 54, disputes this reasoning on the ground that even if the power to purchase its own shares were found in the company's memorandum of association, it would necessarily be void and refers to the judgment of Lord Macnaghten in Trevor v. Whitworth. If it were the only object of the company, it would clearly be illegal under the Companies Act, for no company can be formed for the sole purpose of trading in its own shares. Nor does this object of the company become lawful if legitimate objects are combined with such an object which is not legitimate.

96 Luther v. Luther Co. (1903) 118 Wis. 112; Elliot v. Baker (1907) 194 Mass. 518; Olmstead v. Vance \& Jones Co. (1902) 196 Ill. 236; Borg v. International Silver Co. (1925) 11 F. (2d) 143.

97 Boggs v. Fleming, supra, n. 88.

9n Ballantine on Corporations, supra, n. 7 at 608 and see, infra, Part VII of this paper for a more detailed discussion of the common law safeguards available for an improper share purchase.

90 Scriggins v. Thomas Dalby Co. (1935) 290 Mass. 414.

100 Ballantine on Corporations, supra, n. 7 at 607.

101 These are neatly summarised in Frey, Morris and Chopper, Cases and Materials on Corporations, (1966) at 938.

102 Cartwright v. Dickson (1889) 88 Tenn. 476.

${ }^{103}$ Coppin v. Greenlees \& Ramson Co. (1882) 38 Oh. St. 275; Hunter v. Garanflo (1912) 246 Mo. 131. 
exercise implied the exclusion of all others, and the purchase was accordingly disallowed. ${ }^{104}$ Others found the purchase an impairment of the security of creditors, and the "trust fund" doctrine was thought to compel the denial of any such power. ${ }^{105}$ Some jurisdictions, probing into intracorporate relations, saw an injury to small non-assenting shareholders through a readjustment of voting strength. ${ }^{106}$ The possibilities of abuse, and a realization that the device was a way of evading the statutory method for a reduction of capital motivated other courts, ${ }^{107}$ and a vigorous minority rule developed which followed, with some qualifications, the English law.

As in England, however, exceptions were recognized to be necessary. Thus, even in those jurisdictions adopting the minority view, a corporation was able to take its own stock as security for an antecedent debt; 108 or in compromise of a disputed claim or a hopeless debt;109 or in the case of the insolvency of its debtor; 110 or by way of gift or devise. ${ }^{111}$ The minority jurisdictions also generally thought an exception to the prohibition should be made to permit a corporation to accept the shares issued to a purchaser with an option to return them if he so elects, 112 at times attempting to distinguish this situation from an outright purchase by calling it the failure of a conditional sale, or its rescission. In any case it was generally permitted.

\section{B. Statutory Modification of the Common Law}

The use of the power of a corporation to purchase its own shares as a convenient tool in financing-both good and bad-developed very quickly after 1900 in what was generally a prosperous economy until 1930. The principles of law governing the growth of the subject to that date were beginning to crystallize and undesirable features were being investigated but little was done until the general movement in the 1920's to revise completely the general business corporation laws of the various states. ${ }^{113}$ Initial American legislation on the subject was in the form of a general provision prohibiting the dividing, withdrawing or paying of any part of the capital stock of a company to its shareholders. Such a prohibition was held to prohibit a corporation from purchasing its own shares under such a purchase would result in the withdrawal or payment to any of the shareholders of any part of the corporation's capital stock. ${ }^{114}$

With the general movement to codify and modernize the statutory law of business corporations, a majority of states, in addition to permitting the purchase of shares out of capital in certain special circumstances, ${ }^{115}$

\footnotetext{
204 State v. A. \& N.R.R. (188) 24 Neb. 144.

105 This was the most usual reason given for prohibiting the purchase. Whaley v. King (1918) 141 Tenn. 1; Crandall v. Lincoln (1884) 52 Conn. 73.

106 This problem was seldom considered, however, and then only when concerned with setting a limitation on a power conceded to exist. Borg v. International Silver Co., supra, n. 96.

107 Morgan v. Lewis (1888) 46 Oh. St. 1; Burke v. Smith (1929) 111 Md. 624.

10. Draper v. Blackwell (1903) 138 Ala. 82.

109 State v. Oberlin Building Ass'n. (1879) 35 Oh. St. 258.

10 Bank v. Overman Carr Co. (1899) 17 Ohio C.C. 353.

“I Rivanna Navigation Co. v. Dawsons (1846) 3 Gratt. (Va.) 19.

112 Schultze v. Boulevard Land Co. (1913) 164 Cal. 464.

113 Nemmers, The Power of a Corporation to Purchase Its Own Stock. (1942) Wisconsin Law Review 161. Although a few statutes, most notably those of New York and Delaware, were of earlier origin, most of them were enacted in this era as part of a general movement to codify and modernise the statutory law of business corporations: Doss, supra, n. 67 at 704.

114 Pace v. Pace Bros. Co. (1936) P. (2d) 1.

us For example, for the purpose of compromising a debt or claim, satisfying appraisal rights of dissenting
} 
gave the corporation, and by inference the management, untrammeled discretion to buy shares out of any kind of surplus, or in some states only out of earned surplus, 116 sometimes with a proviso that the purchase could not be made if there is reasonable ground for believing that the corporation was unable or would thereby be made unable to satisfy its debts as they fell due. There were also a number of states whose statutes required the consent of all or the vote of a specific majority of the shareholders to authorize the purchase of its shares. A few states did, however, expressly forbid such purchases.

These original statutory provisions were criticized as being poorly drafted and for the most part sketchy and as showing the same lack of agreement among the states as previously characterized the judicial rules. ${ }^{117}$ The purchase by a corporation of its own shares, like a distribution of dividends, is a method of distribution or withdrawal of assets but is subject to even more potential abuse. As a result, it was argued that what was required was the imposition of carefully drawn legislation as to the conditions under which the purchase of shares may be made, the source or basis of permissible withdrawals for payment, the status of the shares after they are reacquired, the effect of later resale, reissue or retirement of them, the accounting practices to be followed on their purchase or reissue, and the liability of directors and selling shareholders for improper purchases. ${ }^{118}$

Latty, 119 commented on the trend in current statutory provisions involving a purchase of shares as follows:

The 'enabling' spirit of twentieth-century corporation statutes is well illustrated in the evolution of permission to a corporation to purchase its own shares. Its course can be seen in the swing from prohibition of purchase under an ultra vires analysis-in some jurisdictions at least, following the English precedent-to permissive purchase from surplus, and thence to purchase even out of capital in a few favored situations where apparently there were deemed to be overriding considerations of corporate convenience. Ohio led the way in its corporation statutes revision of the 1920's, permitting purchases regardless of surplus in order to redeem redeemable shares, compromise claims, perform repurchase obligations to employees, resell to employees, eliminate fractional shares, resell to other shares repurchased under contract with shareholders, and buy out dissenters entitled to being bought out. Recent legislative activity has added purchases under a contract with a shareholder to buy his shares at his death, purchases by open-end investment companies, and purchases in partial liquidation of the corporation. Increasingly, then, the creditor's cushion afforded by legal 'capital' is being discarded as a mechanism for creditor protection.

Today, all jurisdictions have statutes authorizing and regulating both the purchase and redemption by a corporation of its own shares under varying conditions.120 Ellis and Young ${ }^{121}$ summarized the finding of

shareholders, carrying out a repurchase agreement made with an employee-subscriber and eliminating fractional shares.

116 Carey, Corporations: Cases and Materials, (4th ed.), (1969) at 1590 provides: "In recent years many states have enacted statutes permitting corporations to purchase their own shares but restricting such purchases to purchases made out of surplus or, in some states, out of earned surplus. Some of these statutes, instead of permitting purchases out of surplus only, accomplish the same result by forbidding purchases if capital is impaired or will be impaired by the purchase." Leblovic, supra, n. 4 at $64-66$ categorises the various statutes into three main groups according to whether the purchase is restricted to earned surplus, to any surplus so long as the corporation is or remain solvent, or the most liberal view allowing for a purchase even out of the authorised capital of the company. The topic of surplus will be examined in more detail later in this paper.

11 Levy, supra, n. 5 at 16.

11 Ballantine on Corporations, supra, n. 7 at 610.

119 Latty. Some Miscellaneous Novelties in the New Corporation Statutes, (1958) 23 Law \& Contemporary Problems 363 at 378.

120 For a digest and overview of the various statutory provisions, see Model Business Corporation Act Annotated Vol. 1, (1971), 8. 6 at 256-263.. See also Kessler, Share Repurchases Under Modern Corporation Laws, (1959-60) 28 Fordham Law Review 637. The leading American provisions will be examined later in the paper.

124 Ellis and Young, The Repurchase of Common Stock, (1971) at 3-23. 
various research studies dealing with the extent of corporate stock repurchases and concluded that the birth of large-scale repurchasing had been clearly demonstrated in terms of the aggregate volume of repurchasing, the number of corporations engaging in it, the importance of its impact upon the capital markets, and its role among corporate sources and other uses of corporate funds. Although the rate of growth of corporate share repurchasing may not currently be proceeding at the rapidly accelerating pace of the 1950's and mid-1960's, the importance of repurchasing is still quite evident. Clearly, the extent of the use of this power warrants its detailed investigation as a possible alternative to the present Alberta position.

\title{
IV. THE THEORETICAL NATURE OF THE CONCEPT OF A CORPORATION'S PURCHASE OF ITS OWN SHARES
}

Corporate assets are normally distributed to shareholders by way of dividends. However, another method by which a corporation may distribute assets to shareholders is by the acquisition of some of its own shares, paying or agreeing to pay for them in cash or other property. ${ }^{122}$ For the purpose of this paper, shares are described as "redeemable" if either the corporation or the holder of such shares has the right to have the shares returned to the corporation upon its payment of a stipulated amount, this right arising from an express provision in the corporation's articles or memorandum of association. Redemption is obviously the process of redeeming redeemable shares. ${ }^{123}$ A "purchase" by a corporation of its own shares, on the other hand, differs from a redemption in that the right or duty of the corporation to buy does not arise from a provision in its articles and may not relate to all the shares of a given class; it results from a specific agreement between the corporation and the shareholder which may be entered into either at the time the shares are created or subsequently. In distinguishing between a purchase and a redemption, it has been said that: ${ }^{124}$

\begin{abstract}
... redemption . . . is not subject to the many objections that are apparent in the case of a corporation's purchasing its own shares. Redemption is usually provided for in an instrument with which certain publicity is connected. The right of redemption exists with respect to all shares of a given class. Although there is involved in both a redemption and a purchase a withdrawal of funds that may be necessary for the successful prosecution of the business, there is not in the former case the same danger of prejudicing the rights of prospective investors and creditors that exists in the case of an isolated purchase, since the statement of the redemption rights in the articles of association, by-laws or share certificate at least furnishes such persons an opportunity to become aware of the shareholders' special positions.
\end{abstract}

Many authors characterize a corporation's purchase of its own shares as having some of the economic attributes of a dividend in the sense that payment for the purchased shares is tantamount to a distribution or withdrawal of a portion of the corporate assets to the selling shareholder. ${ }^{125}$ However, as Professor Getz has aptly commented:126

122 Brudney and Chirelstein, Corporate Finance: Cases and Materials, (1972) at 460 provides: "Once the firm has decided what proportion of its annual operating income shall be used to replace existing assets and finance new investments, it will ordinarily distribute any residue (less interest payments) to shareholders as dividends. ... however, management has the alternative of repurchasing stock, thereby leaving a smaller number of shares outstanding among which future dividends will have to be divided."

123 Such shares expressly created as "redeemable" are, in Alberta, preference or preferred shares: s. 69(1) of the Companies Act. A detailed analysis of the concept of the redemption of preferred shares is beyond the scope of this paper and reference thereto is included only as an aid in illustrating the concept of a corporation's "purchase" of its own shares.

124 Note, Redemption of Preferred Shares, (1935) 83 U. of Penn. L.R. 888 at 889.

123 See, for example, Israels, Corporate Practice (revised by Alan Hoffman), (1974) at 349-350 and Ballantine on 
While reacquisition of shares resembles the payment of dividends in that both are methods of distributing (and therefore reducing) corporate assets, there are important differences between the two techniques. To begin with, the results are different. A dividend payment leaves unaffected the recipient shareholder's position as a participant in the continuing enterprise. A repurchase, however, results either in his elimination as a participant, or in a reduction in his interest in the company.127 Second, in the case of dividends the principle of pro rata participation is of the essence, in the absence of some express basis for discrimination. ${ }^{128}$ In the case of a repurchase, however, unless there is a legislative compulsion in favour of equality of participation, discrimination is of the essence of the transaction. This means not only that the interest of a vendor-shareholder may be reduced, but also that it may be reduced disproportionately to that of other shareholders in the absence of some legislative of equality of treatment. Third, whereas a dividend payment is a unilateral act, ${ }^{129}$ a repurchase is a transaction-a consideration that obviously affects the optimum balance of knowledge and information between the company and its shareholders, concerning the payment or purchase, as the case may be.130

The nature of the concept of a corporation's purchase of its own shares can also be characterized by a somewhat broader and perhaps more abstract view. When a corporation purchases (or redeems) any of its own shares, it is in effect a party to a transaction which purports to reverse the process of creating shares by terminating the legal incidents connoted by the shares involved.131 In effect, the function of the capital market, namely to provide capital, through investments, to fund industry, and commerce, is operating in reverse. ${ }^{132}$ In general, repurchasing is intended either to retire shares or to redistribute share ownership. In the latter case, the repurchase decision is implicitly or explicitly associated with a future use through which the corporation will

Corporations, supra, n. 7 at 610. Warren, Safeguarding the Creditors of Corporations, (1922-23) 36 Harv. L. Rev, 509 at 542 states: "If a corporation purchases and pays for shares of its own stock, the immediate effect upon the position of its creditors is precisely the same as if it had distributed a dividend to its stockholders equal to the amount of the purchase price. Assets to the extent of the purchase price are gone. There is nothing in the treasury but a piece of paper which, as it evidences rights subordinate to the rights of creditors, is not an asset available for the payment of debts." Hornstein, supra, n. 17 at 614, however. provides that insofar as concerns the shareholders whose shares are bought, the repurchase is a return of capital as well as an aliquot share of undivided profits.

126 Supra, n. 45 at 10-11. The footnotes appearing in this portion of Professor Getz's article have, however, been inserted, in part, by the writer.

12: Henn, Law of Corporations, (1970) at 683 provides: "A redemption or purchase by a corporation of its own shares sometimes has an effect similar to a dividend, in the sense that each involves the distribution of cash or other property by the corporation to its shareholders. In the case of a dividend, only a distribution is involved, whereas a redemption or purchase involves an exchange, the surrender by the shareholder to the corporation of some or all of his shares."

128 Birch v. Cropper [1889] 14 A.C. 525. See generally, Gower, supra, n. 24 at 349-350.

129 Whereas a shareholder cannot compel the payment of dividends (Burland v. Earle [1902] A.C. 83), he may well be able to compel the purchase or redemption of his shares if the terms of the original subscription so provide.

130 Brudney and Chirelstein, supra, n. 122 at 464 provides: "Entirely apart from its impact on the market price of the stock, a program of corporate repurchases is related to the disclosure of relevant information to the extent that the repurchase is a substitute for dividends. Management's reluctance to contract the total amount of dividends paid from year to year may impel it to seek to avoid raising regular dividends in a given year if it is uncertain about being able to pay similar amounts in suceeding years. The same tendency, although to a lesser desree, may affect payment of 'extra' dividends. The repurchase, made without fanfare, is in effect an extra dividend, but it avoids the exposure of management to unfavourable inferences if not repeated. Repurchase conceals the uncertainty of the pay out. And, of course, in larger terms it conceals the fact that management has no better investment use for the corporation's funds." Ballantine, supra, n. 7 at 622 provides: "Dividends represent a normal distribution in ordinary course pro rata to all of the shareholders of a return on their investment. Repurchases of shares represent a distribution to one or a few shareholders and a return of their original investment in termination of any further rights. In the one case there is complete equality of treatment and it may be assumed by the shareholder to be proper. In the other case there may be many questions of unfairness."

131 Pollis, The Purchase By a Corporation of Its Own Shares of Stock-A Suggested Legislative Approach. (193839) 4 University of Newark Law Review 419.

132 Indeed, it was this facet of a repurchase of shares that caused Professor Getz, supra, n. 45 at 37 concern where he refers to Ellis and Young, supre, n. 121 at $\mathrm{ch}$. V. who, in prefacing their work, remarked that: "In a single recent year almost $\$ 2$ billion was spent by New York Stock Exchange-listed companies alone to purchase their own common stock, close to $\$ 500$ million more than the $\$ 1.5$ billion received by all U.S corporations through the sale of common stock in that year. This was the second twelve-month period when the net effect of a corporate equity financing upon our capital markets constituted a supplying of equity capital to these markets rather than the traditional demanding of funds from them." 
relinquish control of the shares. Thus, this decision is not an investment decision, but rather it is a determination by the corporation of how its ownership will change over time. These actions involve the distribution of corporate profits and benefits despite the general expectation that most internal corporate decisions are limited to the production of wealth. ${ }^{133}$

What is the effect of a corporation's purchase of its own shares? It is obvious that, although the selling shareholder has given up an asset, the corporation has not acquired one. Purchase of a corporation's own shares is quite unlike the purchase of the shares of another corporation. Its own shares are of no value to it unless and until they are resold. Unless the purchase is related to a refinancing, however, its effect is to contract the size of the enterprise and to distribute corporate assets to the selling shareholders-it is a form of partial liquidation. ${ }^{134}$ What has actually happened is that the corporation's assets have been reduced by the amount paid for the shares, while the proportionate interest of each of the other shareholders in the diminished assets has been increased as a result of the reduction of the number of outstanding shares. If, at the time the purchase is made, the corporation does not have an actual surplus or if the amount paid exceeds the surplus, the purchase necessarily operates as a distribution to the selling shareholders of a part of the capital and, to that extent, impairs the capital of the company. The impairment may be intentionally permanent, as where the corporation thereafter treats the purchased shares as cancelled but does not formally reduce its capital. The impairment may be unintentionally permanent to the extent of the full amount paid, as where the corporation finds itself unable to resell the shares at all, or to the extent of part of the amount paid, as where it is only able to resell the shares at a lower price. ${ }^{135}$ It is the possible effects of a corporation's purchase of its own shares that can give rise to a broad range of potential abuses. These potential abuses will be canvassed in detail shortly, followed by an examination of the possible safeguards available should Alberta companies be entrusted with such a power.

\section{THE REASONS FOR A CORPORATION PURCHASING ITS OWN SHARES}

In deciding whether to entrust corporations with a general power to purchase their own shares it is necessary to investigate the numerous possible reasons for such purchases and the practical results that would flow therefrom. This part of the paper will deal only with those purposes or reasons for purchase which are valid and proper and directed towards fulfilment of important business objectives. Purchases for improper purposes will be dealt with in the following part. The reasons for a corporation's purchase of its own shares can be characterized into categories: special circumstances and purchases under a general power to purchase shares. This latter category will be further broken down into the reasons for purchase by a public or listed corporation and by a private or close corporation.

1: Ellis and Young, supra, n. 121 at 55-56.

1.4 Brudney and Chirelstein, supra, n. 122 at 460.

iss Cary, supra, n. 116 at 1590. 


\section{A. Share Purchases in Special Circumstances}

There are circumstances where a corporation's power to purchase its own shares can be applied to the advantage of both creditors and shareholders. For example, the corporation should have the power to purchase its own shares as a means of discharging or effecting a compromise of a debt owned to the corporation, or to purchase the shares of dissenting shareholders under their appraisal rights, or to eliminate fractional shares. As will be seen later, purchases in these special circumstances are dealt with separately by the legislative provisions of the various jurisdictions to be examined.

\section{Compromising Indebtedness to the Corporation}

Sometimes a person indebted to a corporation is also a shareholder. In the absence of other assets with which to pay the obligation, it is certainly better for the corporation to take back stock in settlement of its claim rather than to obtain a costly and troublesome ${ }^{136}$ and most lilely unenforceable judgment for a higher amount. This may be so even though the market value of the shares received may be less than the amount of the debt owed, since the corporation receives the additional benefit of a release of its dividend obligations to the debtorshareholder. ${ }^{137}$ Certainly this opportunity is not to be condemned if it is the answer to a corporation realizing something or nothing on the obligations due it, assuming such debts are bona fide and otherwise uncollectible. ${ }^{138}$

\section{Dissenting Shareholders}

In the early history of the majority American common law rule, an important use of the power of a corporation to purchase its own shares was to meet the problem of dissenting shareholders in a small corporation who could, to the satisfaction of all parties, be bought out with the corporation's funds where the shareholders themselves did not have the necessary capital and there was no other ready market for the shares. ${ }^{139}$ In such a situation, the corporation is anxious to buy out the recalcitrant shareholders and are often actually compelled to do so under "appraisal" statutes. A corporation's right to pay such dissenting shareholders the appraisal value of their shares is thus desirable both from the point of view of the shareholders as well as the creditors since they would usually be only too willing to consent to such a change because conditions within the corporation would presumably improve with internal unity.

\section{Fractional Shares}

Often as a result of a stock dividend shareholders become entitled to fractional shares which are a nuisance since doubt exists as to their actual status. ${ }^{140}$ It is desirable therefore, that a corporation have the power to dispose of such fractional shares by purchase.

\footnotetext{
1:t6 Pollis, supra, n. 131 at 420.

13i Kessler R.A., supra, n. 120 at 645.

138 Counihan, The Power of a Corporation to Purchase Its Own Stock and Some Related Problems, (1946-47) 30 Marquette Law Review 135 at 141 . Nemmers, supra, n. 113 at 165 states that bona fide refers to such facts as whether the stock was fully paid for or was issued at a discount.

t39 Nemmers, supra, n. 113 at 163.

140 Kessler, supra, n. 120 at 646.
} 


\section{B. Share Purchases Under a General Power to Purchase}

\section{Public or Listed Corporation}

\section{(a) Employee share ownership and benefit schemes}

One of the most important uses of the power of a corporation to purchase its own shares occurs when a company wishes to institute a bonus or profit-sharing plan for its employees by permitting them to purchase shares in the company at premium rates or over a long period of time. Since a corporation must have shares available for distribution to the employees, it needs the power to purchase them for that purpose. Further, since the basic reason for share distributions to employees disappears once the latter leave the corporation's employ, employee stock plans usually require the employee to surrender his shares upon termination of his corporate connection. The employing corporation must naturally be able to repurchase such shares to make effective the employee's obligation to surrender them when their purpose of securing his faithful service has ceased. ${ }^{141}$ Although the agreements vary widely, their general purpose is to encourage employee participation in the control and profits of the corporation. ${ }^{142}$ Such plans have merit in that they provide labour with an incentive to work well with management for the success of the corporation, ${ }^{143}$ and can be of tremendous benefit to both employees and the corporation, especially where the corporation is just beginning. ${ }^{144}$ As Professor Dodd explains: ${ }^{145}$

Some labour union leaders and labor sympathizers regard proposals for the purchase of shares of a corporate employer by non-management employees with suspicion as Munich-like appeasement offers aimed at breaking down labor's will to fight for higher pay and shorter hours and at reducing its will to prepare for such fighting by organizing itself. One cannot, however, reasonably expect that the business organizations law of capitalistic society will be based on the premise that anything which tends to dull the fighting edge of labor in a class war with capital is contrary to public policy. In the present state of society, judges and legislators are likely not only to tolerate, but affirmatively to approve plans for giving labor a financial interest in industry through share ownership. Moreover, most of the litigated cases have involved sales of shares to executives rather than to the type of employee who would be regarded as good prospect for labor union membership.

Repurchase agreements are a common, perhaps almost a necessary concomitant of employee-purchase plans, particularly in the case of the smaller corporations. The primary purpose of such plans is to give the employees a stake in the enterprise in which they are employed.146 Generally speaking neither party desires that the stake continue if the employment relationship ceases to exist. One who has formerly worked for, but is now no longer connected with a corporation and who originally invested in its shares because of his employment may well feel that the continuation of this investment under the changed conditions is undesirable, particularly if the shares have no ready market. ${ }^{147}$ The corporation, on its side, is likely for several reasons to desire the power to repurchase the shares on termination of the employment. It may be reluctant to have them remain in the hands of one who may now be in the employ of a competitor. It may wish to acquire them so that it can sell shares to the employee's successor without the necessity of increasing its capital. If the shares have been offered to the employee at less than their value, it will seek to prevent his profiting from this low offer by quitting his job as soon as he has acquired the shares.

141 ld. at 647 .

142 Nernmers, supra, n. 113 at 164.

143 Counihan, supra, n. 138 at 141.

14. Leblovic, supra, n. 4 at 71.

is Dodd, supra, n. 67 at $715-716$.

- 146 The sale of securities to employees may also be motivated to some extent by the desire to tap an additional source of new capital and to do so without incurring any stock-selling expense.

117 Moreover, most such plans provide for payment for the shares by instalments. An employee who loses his job, perhaps without obtaining another, is not likely to be in a position to continue instalment payments, and naturally desires to have the payments already made refunded. 
Closely connected to the benefit or incentive plan is the pension or retirement benefit arrangements possible under a corporation's power to purchase its own shares. ${ }^{148}$ Many American companies follow the practice of making all or part of their annual contributions to pension funds, stock options or bonuses, profit-sharing programs, or thrift incentive plans, in their own common stock. Typically, their contributions are expressed and obligated in dollar terms, and the dollars are simply converted into shares prior to delivery. Use of the company's own shares is favored because of the potential for employees to identify their personal financial interests with the value of the company's shares over the longer term..$^{149}$

\section{(b) Facilitating mergers and acquisitions}

Another important reason for a corporation purchasing its own shares is to have a sufficient source of shares to facilitate mergers and acquisitions through the medium of the share exchange. The advantage of the power to purchase its own shares in this situation is that the corporation is not required to dilute its equity base by the issue of new shares. ${ }^{150}$

\section{(c) Reorganization of the corporation's capital structure}

The power of a corporation to purchase its own shares increases its flexibility in reorganizing its capital structure so as to be more effective and in accordance with its needs. A purchase by a corporation of its own shares, like the purchase of its outstanding bonds or debentures, may be regarded as an incident of adjusting its financial structure to the needs of the business. ${ }^{151}$ For example, the power to purchase its own shares enables a corporation to fulfil its obligations under convertible debenture or share warrants without jeopardizing the existing equity base. ${ }^{152} \mathrm{~A}$ corporation may also for reasons of financial policy, wish to alter its debt-equity ratio by resorting to increased debt financing using borrowed funds to purchase some of its outstanding shares. ${ }^{153} \mathrm{~A}$ corporation might also feel it is necessary to contract its equity base. Such a situation may arise where a corporation feels that its opportunities for further profitable investment are limited and its present cash generating abilities are far in excess of its requirements. The directors may well wish to avoid the declaration of increased dividends ${ }^{154}$ and the purchase of some of its outstanding stock provides a viable alternative. The

14t Leblovic, supra, n. 4 at 71 .

149 Ellis and Young, supra, n. 121 at 56: "An extension of this desire to integrate the worker's financial goals with those of the stockholder is found in a relatively small number of larger corporations which are principally or even entirely owned by the employees. In these cases, the corporation repurchases shares from retiring workers and redistributes them to others, entering or advancing within the company."

150 The true advantage of the power of a corporation to purchase its own shares in a merger or acquisition is where the seller insists on a common stock exchange to avoid immediate taxability and the purchasing corporation wants to make a cash deal to avoid equity dilution. The purchasing corporation can use its surplus cash to purchase a sufficient number of its own shares, thus maintaining its equity base intact, and then enter into the share exchange. See Ellis and Young, supra, n. 121 at 57.

15) Ballantine, supra, n. 7 at 604. Detailed Background Papers for the Canada Business Corporations Bill at 9 provides: "Completely new, however, is the right of a corporation to acquire its own shares, enabling a corporation better to adjust its financial structure to the needs of the business, parallel to the manner and for the purpose that corporations now acquire their own debentures in market transactions.

1s: Ellis and Young, supra, n. 121 at 58 note a different form of dilution, dilution of dividend payments, during adverse industry conditions. A company may be able to maintain its cash dividend payment by reducing the number of shares on which the dividend would be payable by regularly purchasing outstanding shares. It would seem, however, that if funds were available for purchase, they would have alternatively been available for maintenance of dividends in any event.

15.1 The pre-tax deductibility of interest payments would be one of the more important reasons for such a decision.

ind This may be because of the increased tax liability to shareholders or, perhaps more importantly, because the increased dividends will not be able to be maintained in the future. 
selling shareholders are given the opportunity to realize their investment $^{155}$ and to acquire equity in a more dynamic venture, while the corporation solves its problem of surplus funds, and with the concurrent diminished capitalization, increases its own earnings per share. ${ }^{156}$

\section{(d) Investment in the corporation itself}

Investment in a company's own shares may be considered the best available use of its surplus funds, especially where management takes the view that the market price of the shares is lower than their true value and a profit can be made upon their later reissue. ${ }^{157}$ During periods of stock market decline, the number of American corporations engaging in the practice of purchasing their own shares and the frequency of their purchases generally increases. This was certainly true following the market crash of 1929, and the pattern appeared to hold true following the market decline of mid-1962 158 and in 1969-70.159 A recent commentary on the purchase of shares for this purpose and its rationale provides: ${ }^{160}$

In the recent period of falling prices, an increasing number of public corporations have decided that the price of their own stock is now a bargain and have entered the market to purchase it. This can make a great economic sense. For example, if a corporation sold stock to the public a year ago at $\$ 30$ per share and can now go into the open market and purchase its own shares at $\$ 15$ per share, the dilutive effect of the prior sale can be reduced, and the corporation can purchase the same number of shares it sold for only half the price.

Similarly, if the corporation recently made an acquisition using securities rather than cash, the dilutive effect of the issuance of shares can be greatly reduced.

\section{(e) Miscellaneous purposes}

In addition to the important use of the power of a corporation to purchase its own shares outlined above, other valid reasons for such transactions exist. Some of the more widely-known ones are: the elimination of small shareholding where the cost of servicing outweighs their significance;161 the selective reduction of capital;162 accommodating insiders by permitting a large shareholder to eliminate its holdings in the corporation;163 increasing the equity base of the corporation by

155 At capital gains rates.

150 Leblovic, supra, n. 4 at $72-73$.

15i Getz, supra, n. 45 at 26. See also Brighani, The Profitability of a Firm's Purchase of its Own Stock, (1964) 7 California Gt. Rev. 69; Note, Rule $106-5$ and Purchases by a Corporation of Its Own Shares, (1966-67) Nw. U.L. Rev. 307 at 309-310; and note the comment by Brudney and Chirelstein, supra, $n$. 30. It is arguable, however, that a corporation's profitable investment in itself suggests that the corporation is deriving a benefit at the expense of the selling shareholder. It must be remembered firstly, however, that in such a situation the shareholder is never obliged to sell and secondly, adequate disclosure provisions imposed on the corporation as an "insider" (which will be discussed later in this paper) can prevent the type of abuse contemplated.

15s Zilber, Corporate Tender Offers for Their Own Stock: Some Legal and Financial Considerations, (1964) 33 Univ. of Cincinnati L. Rev. 315.

159 Ellis and Young, supra, n. 121 at 57: "During and after major declines in the common stock market, such as occurred in 1969-70, corporations will repurchase stock because the current market price is less than the preceived long-term value of the common shares."

160 Stone, A Corporation's Repurchase of its Own Shares, [1974] Los Angeles Bar Bulletin 106 at $106-109$.

181 Zilber, supra, n. 158 at 319 provides "The expense of printing and mailing notices, reports and dividends to small shareholders may often by disproportionate to or exceed the earnings on their shares, and for that reason the corporation may wish to eliminate these very small holders." See also Ellis and Young, supra, $n$. 101 at 6984 .

162 Frey, Morris and Chopper, supra, n. 101 at 937.

16.3 Ellis and Young, supra, n. 121 at 59 provides: "Another important category of repurchase motives is to provide a direct personal benefit to individuals and groups closely associated with the repurchasing corporation. A common situation arises with the desire of a large stockholder to sell his holdings for any of a wide range of reasons. If the public market for the shares is not broad and deep, a secondary distribution of a large block of stock may lead to a significant decline in the quoted price of the stock until this overhanging supply has been absorbed. Such accommodations have been arranged at or below current market quotations for a resigning officer, a founder's estate, and a director's widow, as well as for large owners." 
obtaining broader public ownership of the corporation;164 and overcoming technical problems. ${ }^{165}$

The following three purposes for a corporation's purchase of its own shares have been segregated because they fall very close to the albeit obscure dividing line between purchases for valid purposes and those for improper purposes, the subject of the next part of this paper. Whether or not the following purposes are proper or not often depends on the circumstances giving rise to the transaction, the mechi.nics used to carry it out and the particular results that flow from it.

\section{(f) Agreement to purchase in original subscription agreement}

Although the mere existence of the power in a corporation to purchase its own shares provides an otherwise unavailable additional market to a shareholder desiring to sell his shares, some corporations go further and agree to purchase the shares at a future date and under certain circumstances as part of the original subscription agreement. $A$ corporation may utilize such an agreement to attract initial capital which might otherwise be difficult to obtain, and yet is necessary to get the enterprise under way, or to advertise as a "selling point" the name of the shareholder, thus stimulating other share subscriptions and credit extensions. ${ }^{166}$ The most common type of such agreements is a promise made to a prospective subscriber that if the latter will subscribe and pay for the shares, the corporation will subsequently repurchase them at the original price should the subscriber become dissatisfied with his bargain. ${ }^{167}$ Although a potent sales feature, ${ }^{168}$ the possibilities for abuse are obvious. Such agreements have been criticized as being prejudicial to creditors and shareholder alike as being calculated to deprive the corporation of capital at the time when it needs it the most ${ }^{169}$ and as being patently unfair to those shareholders and creditors who relied on the faith of the stated capital of the corporation without knowledge of the existence of such agreements between the corporation and other, often major shareholders.170 The prevention of potential abuse arising from the use of such agreements, if they are to be allowed at all, will be examined later in the paper dealing with possible safeguards.

\section{(g) Support and manipulation of the market price of shares}

The mere creation of the power in a corporation to purchase its own shares gives rise to a potential buyer whose existence alone may give some support to the market price of the shares. There is no doubt that support of the market price, if calculated to level occasional disturbances or to parry attacks, is highly desirable and there can be no objection if

164 Zilber, supra, n. 158 at 318.

165 Ellis and Young, supra, n. 121 at 59 provides: "Repurchasing has been used as a means of both partial and full liquidation of a corporation, typically after operating assets have been sold to another corporation. In some partial liquidations, repurchase programs have been extended over periods of several years.

A variety of other technical or procedural difficulties had been resolved or simply eliminated through repurchases. Assets not qualified for ownership by regulated companies have been exchanged for common stock. Antitrust suits against intercorporate stockholdings have been averted through repurchase. Court suits over voting rights, litigation by stockholders, and efforts to obtain favorable tax status have all been behind specific repurchase programs."

From a financial management point of view, Ellis and Young at 63-97 is instructive.

166 Kessler, supra, n. 120 at 647

16: Dodd, supra, n. 67 at 712 . There may also be time limits attached and availability only under certain conditions.

Ion Levy, supra, n. 5 at 3.

169 Dodd, supra, n. 67 at 712.

170 Nemmers, supra, n. 113 at 165. 
such action were undertaken by interested investment dealers or major shareholders. ${ }^{171}$ It has been suggested that it is equally unobjectionable where, in an effort to support the market price of the shares and protect against professional manipulation, a large block of shares overhanging the market and threatening to depress the prices of the stock on the exchange are purchased by the corporation itself. ${ }^{172}$ However, as Professor Getz states:173

It is a commonly-expressed concern, however, that companies may use the power to repurchase their own shares for the purpose of manipulating the public market in those shares-in particular, by maintaining the market price. Indeed, it has been suggested that management may have strong temptations to do so:

'First, increased prices solidify management's position vis-a-vis the shareholders whose primary concern is the value that their holdings will bring on the market. Second, increased prices make it more costly, and hence more difficult, for an outsider to take control of the corporation by way of a tender offer. Third, they help mask any instances of corporate mismanagement. Fourth, if the corporation is to engage in a merger or acquisition, which requires payment by the corporation of its own shares, the number of shares that will have to be paid will be reduced in accordance with any increase in the market price of the shares up to the time of the consummation of the agreement. Fifth, since officers and directors are likely to own stock in the corporation, the law permits them to sell that stock. Finally, increased prices can produce a snowball effect by making the corporation look more attractive to new investors, they increase demand which raises the market price even higher.'174

An almost classic example of manipulation through share repurchases is described in the following financial advice given to the management of a listed company in the United States:

'SP should advance continually the market price of its shares from the prolonged, rather static range in the low 30's commensurate with the carrying out of this program and general economic and market conditions. Such advance should be implemented by South Penn or one or more of its officials on its behalf, by purchasing shares of South Penn on the open market on the [American Stock Exchange]. The relatively small floating supply of shares . . . of this long, generous dividend payer, should make a relatively easy job of continually advancing SP's market price and such advance will be assisted substantially (if not taken over in a major way from time to time by the investing public and brokerage fraternity) when it becomes apparent through publicity and market action that SP has entered on an accelerated expension program. At the moment, on the basis of 1961 earnings of $\$ 2.40$ per share, SP's shares at around $\$ 32.00$ are selling at only about 13 times earnings whereas they could and should be selling at at least 20 to say 23 times earnings or around $\$ 48.00$ to $\$ 55.00$ per share. This 20 times (plus) ratio will materialize without difficulty as soon as the investing public learn that

171 Nussbaum, supra, n. 66 at 987.

172 Leblovic, supra, n. 4 at 73. Nemmers, supra, n. 113 at 166-167 provides: "Once a corporation's stock is listed on an exchange, it is a common rule of the financial world that such corporation must be prepared to support its stock on the market and guard it from becoming the football of professional manipulators. For a corporation to refuse to support its own stock may be fatal, since depressed prices on the stock exchange, even artificailly depressed prices, sooner or later affect sales and credit standings. The argument for permitting a corporation to deal on the exchanges in its own stock thus, is the same as that which supports the existence of the exchange itselt, the 'stabilizıng' result achieved by free-trading. But abuses are ulimited. Dealings confuse earnings and losses in annual reports under many modern statements which do not distinguish between an operating statement of ordinary business transactions and a general profit and loss statement. Such manipulations may throw a corporation into insolvency or deeper into insolvency. It is true that the majority American rule is hemmed in by the usual fraud and fiduciary qualifications, but these may be small comfort when the burden of showing violations is on the plaintiff stockholder, especially where the corporation is large and the stockholder is small."

Berle and Means, The Modern Corporation and Private Property, (1932) at 174-175 provide: "On the other hand, there is something to be said for permitting a corporation to buy shares of its own stock, especially where the market machinery has temporarily broken down. During the panic of November, 1929. many corporations were urgently asked to use their surplus funds for such purchase. The incidental effect was to shift the asset values of the remaining outstanding shares. But the motive was to provide market purchases for shares of stock, and to keep running the mechanism of the public market. It is difficult to regard this process as anything other than a legitimate use; it was, in fact, the only available means of safeguarding a decent market appraisal for the bulk of the stockholders."

Although their view was subsequently criticized by Nussbaum, supra, n. 66 at $986-990$, they repeated it verbatim in the revised edition of their work in 1968 at 160.

17. Getz, supra, n. 45 at 33-34.

1it Moskowitz, Corporate Stock Repurchases Under the Securities Exchange Act of 1934, (1971) 51 Nebraska Law Review 193 at 226. 
SP has embarked on a constructive aggressive expansion program. . . .

The shares purchased in the open market as above mentioned as well as Tidewater's SP shares, if purchased, can, of course be used in negotiating future property acquisitions ... then SP shares market price could continually make new highs, with occasional market help of SP.

South Penn's leading the way, from time to time, in continually advancing the market price of its shares consistent with the circumstances as mentioned, will be beneficial to the company in many ways, especially in establishing a much higher and more favourable price-structure basis on which to negotiate thru shares, well selected property-reserve acquisitions in its expansion program. . . .

Earnings-expansion through acquisition ... (of reserve)... thru merger and/or purchase ... with payment for same being made by the company out of its treasury and increased shares at advanced stock market prices for SP shares as above mentions. . . .'175

The prevention of potential abuse arising from share purchases in such circumstances, which involves securities exchange regulation, will be examined later in the paper when dealing with possible safeguards.

\section{(h) Maintaining and manipulating corporate control}

An important aspect of the power in a corporation to purchase its own shares is that it permits a closely-held public corporation to retain control where the only alternative is a sale of a substantial block of shares to a market unfriendly to the existing shareholder group. Such purchases may be desirable, from management's point of view, to prevent shares from falling into the hands of syndicates, either within or without the corporation, desirous of taking over the corporation merely to "milk" it (either through liquidation or improvident dividend payments at the expense of capital improvement), and incidentally, at least, to protect their own jobs as directors and officers from the inevitable dismissal which a change in majority share ownership augurs. Prudent share purchases may therefore be used (for good or ill) as a way of manipulating corporate control. ${ }^{176}$ In one of the leading American cases, a share purchase resulting in the maintenance of corporate control was upheld upon the directors satisfying the burden of showing reasonable grounds to believe a danger to corporate policy and effectiveness existed by the presence of an outsider, who had a reputation as a liquidator of corporations, purchasing large amounts of the corporation's stock. ${ }^{177}$ The prevention of the potential abuse that can arise in such circumstances, which involves the imposition of personal liability on the directors for improvident share purchases, will also be examined later in the paper when dealing with possible safeguards.

\section{Private or Close Corporation}

The power to purchase its own shares can also be an important and useful tool for the private or close corporation. Though many of the reasons for purchase related to the public corporations noted above are equally applicable to the close corporation, the fact that such an entity is often, in effect, little more than incorporated partnership, closely bound, often family owned and has little relation to the general public gives rise to a number of important reasons for it purchasing its own shares.

\footnotetext{
175 Davis v. Pennzoil Co. (1969) 264 A. (2d) 597 (Penn. S.C.).

${ }_{176}$ Kessler, supra, n. 120 at 648. See also Ellis and Young, supra, n. 121 at 58-59.

1 i7 Cheff v. Mathes (1964) 199 A. (2d) 548 (Delaware S.C.); see Bergmann, Directors' Right to Purchase Company Shares With Company Funds, (1965-66) Corporate Practice Commentator 362; see also Note, Buying Out Insurgent Shareholders With Corporate Funds, (1960-61) 70 Yale LJ. 308.
} 


\section{(a) Maintenance and flexible transfer of control}

The essence of the success of a private corporation is that control thereof is retained by those persons having a direct interest in the furtherance of the business. As is the case with many a successful enterprise, a third party intermeddler will often attempt to gain control of the corporation from the owners for no other purpose than to divert its profits to some outside venture, leaving the corporation bankrupt. To prevent such a situation from arising it is necessary for the financial affairs of the corporation to be carefully arranged so that a substantial block of its shares do not become available to an outsider. Although this can perhaps be done by way of a right of pre-emption in the other shareholders, quite often the value of such a purchase may far exceed the available resources of the individual shareholders, while the corporation itself may well have sufficient funds to easily purchase the shares thereby removing the possibility of third party intervention. ${ }^{178}$

In addition, where the controlling block of shares in a private corporation is being transferred, the usually encountered stumbling block of insufficient funds on the part of the purchaser can be avoided by having the corporation itself purchase part of the shares and the purchaser the controlling balance. The net result is that the seller realizes the full value of his shares and while the purchaser is required to expend a lesser amount of cash and since the total number of shares outstanding is reduced his block of shares still represents the controlling factor in the corporation. ${ }^{179}$

\section{(b) Death or retirement of a shareholder}

Closely connected to the issue of control in a private corporation is the situation where one of its shareholders dies or decides to retire. The power in a corporation to purchase its own shares "... provides a much-needed flexibility for closely-held companies and their shareholders"180 in such circumstances. Professor Kessler provides: ${ }^{181}$

Repurchase agreements are even more important for close corporations. In the typical close corporation the shareholders are also the most important employees. The corporate form of business has been chosen solely for its advantage of limited liability: the participants regard themselves as partners, and desire to have the same control over the entry of new "partners" as exists in legal partnerships. Such corporations, therefore, in addition to the typical "veto" powers given shareholders (to render the corporation as much like a partnership as possible), usually also have stock repurchase agreements so that the remaining "partners" may determine who shall be their new "partner" when one of their number dies or decides to terminate his participation. Shareholder agreements in a close corporation often obligate the corporation, rather than the individual stockholders, to repurchase the departing (or departed) shareholder's interest, rendering imperative a corporate power to repurchase in order to effectuate these agreements.

17s Leblovic, supra, n. 4 at 74. Related to this issue of maintenance of control is that of retention of an established policy in a private corporation. Commenting on this, Counihan, supra, n. 138 at 139 provides: "This would be particularly applicable to close corporations which classification comprises a sizeable proportion of all corporations in the United States. The purchase of a block of stock in a close corporation by an outsider might create a complete change in policy, management and earning capacity for the corporation. Many years of hard work in developing a close corporation may be jeopardized by the sale of some stock to a stranger whose only interest, for instance, is the payment of dividends. Such sales may often be avoided during the lifetime of the stockholder by purchase of available stock by other stockholders or by the corporation itself."

179 Leblovic, supra, n. 4 at 74.

${ }^{380}$ Interim Report of the Select (Lawrence) Committee on Company Law, Ontario, (1967) para. 528. (Hereinafter referred to as the Lawrence Report.) A purchase of shares in such circumstances was also felt to be the most important reason for the existence of the power by Iacobucci, supra, $\mathrm{n} .51$ at 119.

int Kessler, supra, n. 120 at $647-648$. 
Whenever a shareholder of a private corporation dies or retires, the necessity of having sufficient cash resources available arises so that the liabilities that accompany such circumstances can be met. ${ }^{182}$

Where a shareholder in a private corporation dies, the need for funds is almost always immediate. Very often the shareholder's estate is, to a great extent, composed of shares in the corporation and because of the tax liability occasioned on death, ${ }^{183}$ the estate must find a ready buyer for them. By their very nature, however, such shares are rarely saleable in the open market at anything but sacrifice prices and yet such prices must often be accepted by the estate to fulfil its immediate obligations. Secondly, the suddenness of the death may find the other shareholders unprepared for the burden of purchasing these shares, even at reduced prices. The result is that the door is opened for the intervention of a third party outsider who either buys in to "milk" the company or, under the deceased shareholder's will, becomes an inactive and unproductive owner who is nevertheless collecting his or her share of the profits.

Where one of the shareholders retires from the corporation the factor of immediacy is not as important as it is with death, but since the retiring shareholder may well wish to sell his shares so as to realize an immediate cash benefit, the liquidity and control issues mentioned above will eventually become a problem for the corporation and the remaining shareholders.

These difficulties may be and in fact are met, to some extent, today with the use of complicated buy-sell, cross-purchase insurance schemes which require the declaration of substantial dividends or bonuses by the company in order that the annual premiums might be met. Though the result of such plans is to permit the remaining shareholders to purchase the shares of the deceased shareholder (assuming of course that all of the participants in the scheme are insurable in the first place), the additional effect of the dividend or bonus declaration is to deplete the working resources of the company and to increase the tax liability of the recipients thereof.

The power of a corporation to purchase its own shares is a valuable tool in solving the problems raised above. The corporation itself can purchase all or part of the shares in the event of a death or retirement of one of the shareholders and yet, until required, this same fund can be utilized for business purposes, and neither the seller (be it the retiring shareholder or the deceased shareholder's estate) nor the remaining shareholders are prejudiced by the possibility of a sale on the open market. ${ }^{184}$

isi See generally Leblovic, supra, n. 4 at 75-76.

in: Apart from administration costs, the major tax liability arises by virtue of the "deemed disposition on death" of the deceased's capital property under section 70(5) of the Income Tax Act, S.C. 1970-71.72, c. 63 (as amended) which gives use to a capital gains tax. The situation is not so acute, however, as in other provinces since Alberta does not levy an estate tax on a deceased's estate or a succession duty on the heirs.

in Both the requirements of liquidity and maintaining the coorporation "close" are satisfied in this way. See Goodman, Corporate Share Purchases Schemes In Estate Planning [1974] 1 Estates and Trusts Quarterly 227 for a further discussion of the problems and the use of the corporate purchase tool in estate planning in Ontario. The fact that the corporation itself can hold the policies and pay the premiums is an important advantage. The basics of the plan used in the United States is outlined by Counihan, supra, $n$. 138 at 140-141: "Briefly the mechanics of such plan are that insurance is procured on the life of the stockholder and a trustee is named as beneficiary of the policies. Ordinarily in a close corporation most of the stockholders are officers or directors, or in some measure actively take part in the business and there is no question that the corporation has an insurable interest in the lives of such officers who are mainly responsible for its success. The corporation has no insurable interest in the lives of stockholders merely through such relationship alone, but ordinarily special services, skill, and knowledge contributed by the stockholders, most of whom are usually employees, in a close corporation, will furnish an insurable interest. It has been held that insurable 


\section{(c) Removal of dissident shareholders}

Another closely related circumstance wherein the power of a private corporation to purchase its own shares is advantageous is where internal dissension has arisen amongst the shareholders. In the small private corporation, a definite amount of harmony and unity amongst the shareholders is essential since differences over policy are likely to be disastrous. Because of the lack of a ready market for shares in such companies, and the inadvisability of dissolution, the retirement of one of the factions is most easily brought about by a surrender to the corporation of all or part of its shares and the vesting of ownership of the enterprise in the remaining members. ${ }^{185}$ In this way the problems of liquidity and control are again satisfied. Although the possible effect on creditors may not be considered by the parties because the smoothing of the ruffled internal affairs occupies their entire attention, in most cases creditors would not object since the corporation is either in a healthy state or it is thought it will become so when the undesirable members cease to be troublesome factors. ${ }^{186}$

\section{POTENTIAL ABUSES}

Along with its potential advantages, however, the existence of the power in a corporation to purchase its own shares may also give rise to potential abuse. Indeed, it was this potential abuse that led many leading American and English jurists to criticize the American common law position which allowed such purchases with inadequate safeguards. This part of the paper will examine these potential abuses and in particular will examine how the purchase by a corporation of its own shares may threaten the interest of creditors, shareholders and the general investing public. Although all of the potential abuses can have an effect on the interests of the three groups, it is possible to delineate the abuses amongst the groups so as to highlight the major areas of concern.

\section{A. Creditors}

The major potential abuse is that a corporation's purchase of its own shares impairs the creditor's margin of safety against the depletion by the corporation of its assets and the impairment of its capital. The principle that the creditors of a corporation have a right to rely on the maintenance of its paid-up capital as a source or guaranteed fund to look to for the payment of their claims was the principal rationale of the

interests exist in the lives of stockholders in a close corporation inasmuch as there is a threat of outsiders entering the business to the detriment of existing stockholders upon the death of the present stockholders.

The agreement between corporation and stockholder provides that on the death of the stockholder the proceeds of the policies will be paid to the estate of the deceased by the trustee, and the stock will be transferred to the corporation. To insure the fulfillment of the agreement and the procurement of the stock by the corporation, the desired number of shares to be sold to the corporation is deposited with the trustee with the rights incident to such stock, such as dividends, voting, stock "split-ups". stock dividends, etc., remaining with the shareholder or given to the trustee by power of attorney. The use of a trustee and the deposit of the stock avoids dissension and a change of mind by the parties at a later date... Such a plan not only provides the corporation with liquid funds when required, but also permits the deceased shareholder's estate a proper price for the stock as well as the advantage of ready cash to meet the usual high estate taxes, expenses of administration and last illness, and burial expenses. The purchase price to be paid by the corporation can be agreed upon during normal times without the stress of grief and death. A prearranged plan of evaluation of the stock interest or a stated price of sale can be arrived at during the deceased's lifetime and subsequent disputes avoided."

is Counihan, supra, n. 138 at 141 provides: "This problem does not exist in large corporations where stocks are freely traded on the stock exchanges, but is confined to small, close corporations. More harmonious relations can sometimes be obtained by the elimination of an antagonistic shareholder, and in the absence of a ready market for his shares or a sale to one or the other stockholders, purchase of his shares by the corporation is the only answer." See also Cary, supra, n. 116 at 1589 where an example of such a situation is given.

ins Levy, supra, n. 5 at 1-2. 
English common law rule prohibiting such purchases and provided ammunition for those jurists critical of the American rule:187

It has been urged by able writers that the policy of the law as to protection of capital is not consistently carried out and that many abuses are made possible by permitting a corporation to deal in its own shares. There is no doubt that as Morawetz says, such power is 'a fruitful source of unfairness, mismanagement and corruption.' purchase of its own shares is a method of secret withdrawal and distribution of current assets which may be needed in the business, or may be discriminatory, or a means of speculation with the corporate funds.

When a corporation purchases its own shares it parts with an asset (namely the purchase price) in exchange for, in effect, nothing. Whereas a corporation's purchase of shares in an independent enterprise results in the corporation receiving an asset of possible value to creditors, upon a purchase of its own shares the purchase price is simply withdrawn from the business. Nothing of value to creditors takes its place except what is in reality an unissued share. ${ }^{189}$ Although it is arguable that if, when the shares are reissued, they bring in at least the former purchase price, the balance is re-established, this outcome must not be anticipated in law. There is no certainty that the company will be willing or able to reselll the shares in the future. 190

A corporation's purchase of its own shares is to be distinguished from a redemption of shares since there is no advance notice or disclosure of the price to be paid for the purchased shares. With redeemable shares a negotiated or somewhat fixed redemption or purchase price usually exists from the outset and is stated in the corporation's charter, whereas with common shares the directors can in each case determine the price with the shareholder concerned, subject to the directors acting in the best interests of the corporation. ${ }^{191}$

It has also been argued that it makes no difference whether the corporation is solvent at the time it purchases its own shares or not since in any event the ability of the corporation to pay its creditors is nonetheless decreased: 192

It is no answer to say that if the company is thoroughly solvent, so that its assets after the purchase are still amply sufficient for payment of all claims against it, the creditors are not prejudiced. For, while the assets may still remain sufficient, yet they are after the consummation of the purchase, undeniably less by the amount of the purchase money than they were before; and hence the fund which the creditors had an absolute right to have preserved intact for the payment of their claims, has been diminished without their consent.

Thus, it is clear that a corporation's purchase of its own shares has consequences that directly affect creditors. There may, however, be a difference as between current creditors and long-term creditors such as bond or debenture holders. If the corporation is solvent at the time of the

1s: Ballantine, Questions of Policy in Drafting a Modern Corporation Law. (1930-31) 19 Calif. L. Rev. 465 at 479.

1ns Morawetz, Private Corporations (2d ed.) 113, English jurists supported the English rule on similar arounds. For example, Pennington, Company Law (3d ed.), (1973) at 160 provides that the rule preventing a corporation trom purchasing its own shares is part of the larger rule preventing an unauthorized reduction of the issued capital of the corporation which is designed to ensure that creditors are not defrauded by the company's assets being distributed amongst its shareholders, or by the company relessing its shareholders (often including the directors) from liability for uncalled capital, and to ensure that any reduction of capital is fair as, between different classes of members of the corporation.

1s\% Ballantine on Corporations, supra, n. 7 at 603 .

isv Nussbaum, supra, n. 66 at 993.

Iyı Iacobucci, supra, n. 51 at 119.

192 Machen, Modern Law of Corporations, 8. 626. It can be argued as well, however, that a solvent corporation could distribute dividends in such a situation in any event and thereby similarly reduce its assets. 
purchase, the current creditors can still enforce their claims. Long-term creditors, however, whose risk is a continuing one, must take the risk of future solvency as they await maturity of their claims. ${ }^{193}$

\section{B. Shareholders}

Not only are creditors potentially imperiled by a corporation's purchase of its own shares, the effect rebounds to the possible detriment of both the non-selling and, in some cases, the selling shareholders, and can affect them in a variety of ways. When a corporation purchases its own shares, assets which could otherwise be used to earn income are distributed. The resultant lack of liquidity, caused by the purchases may prevent payment of dividends ${ }^{194}$ and earnings may also fall out of proportion to the reduction in assets. ${ }^{195}$

When a corporation purchases its shares out of capital, it retires from its capital a sum which was originally contributed for the prosecution of its business and may leave available for that purpose a smaller sum than that on which some shareholders might have originally insisted before entering the corporation. Levy provides:196

For the majority rule, it may be argued that by this 'reduction' of outstanding stock the remaining shareholders stand a chance of getting an increased dividend, as treasury stock is not counted as outstanding stock entitled to share in profits. The answer is that their share of possible losses is also increased. And further, though certain claims upon future dividends are extinguished by creating treasury stock through purchases, at the same time a corresponding quota of working capital is destroyed. With a decreasing working capital the profits of the business will most probably be smaller and the pro rata share of the remaining shareholders will not be enhanced by the transaction. . . And the management is here altering the original corporate structure on which the subscriber might be presumed to have relied when he entered the venture.

Nor is the situation greatly improved when the purchase is made out of surplus, at least so far as objecting shareholders are concerned. Shareholders invest their money in stock as in most other things for the realization of profits in the form of dividends. The directors of a corporation, however, are usually vested with a considerable amount of discretion in deciding in what instances profits shall be paid out to the shareholders as dividends for it may be good business policy to build up a reserve or surplus account for a variety of reasons. But it is hardly anticipated by those who buy shares that profits will be diverted to permit some few members to retire their capital contribution and share of the surplus from the venture, thereby postponing the payment of dividends to others. ${ }^{197}$

Another cause of concern to shareholders is that the resultant decrease in the total of outstanding shares may alter voting control

193 Cary, supra, n. 116 at 1590 . Nussbaum, supra, n. 66 at $995-996$ provides that the American common law rule denied protection to a creditor who came into existence after the purchase was accomplished, the point apparently being that in such a situation the creditor is not deprived of any right or interest he ever had in the company. He suggests, however, that reliance on the existence of capital once issued must be protected even if the relying creditor acquires his right after the capital stock has been impaired. The problem may be different where the creditor in acquiring his right has knowledge of the purchase since denying protection to him would be less objectionable.

194 Nussbaum, supra, n. 66 at 985.

195 Hornstein, supra, n. 17 at 615. It is also argued that the mere existence of the power to purchase shares may give rise to rash speculation in the market by the directors: Howard, The Proposal for a New Business Corporations Act for Caneda: Concepts and Policies, (1972) L.S.U.C. Special Lectures 17 at 43 . This can be "economically unproductive and basically more vicious than speculation in the securities of other companies": Levy, supra, n. 5 at 8.

146 Levy, supra, n. 5 at $25-26$.

19: Id. at 26. 
within the corporation. If the reacquired shares carry voting rights, control is directly affected, for example, purchase by a corporation of $15 \%$ of its outstanding shares would transform a $40 \%$ shareholder into a majority shareholder. ${ }^{198}$ Although in the United States it has been held that reacquired shares cannot be voted, ${ }^{199}$ this does not completely remedy the abuse since by using the corporate funds to purchase some of the outstanding stock and retire it from the voting arena, what was before a minority in the controlling group can be converted into a majority, and their control may therby be perpetuated indefinitely. ${ }^{200}$ Whether or not a majority can be acquired in this way very often, their relative voting strength, at any rate, can be increased. Further, such purchases can enable an incompetent management to remain in control ${ }^{201}$ by, for example, having the corporation purchase its own shares on the market in an effort to frustrate a potential take-over bid.202

Although management's use of corporate funds to purchase stock held by potential insurgents may protect the corporation from being taken over by less competent or perhaps unscrupulous management, the power to make such purchases can also be an effective device which the incumbent management may use to insulate its position against shareholder action. ${ }^{203}$ For example, such a purchase may be used to buy off shareholder-opponents of the management without regard to whether their opposition is beneficial or harmful to the corporation. ${ }^{204}$ In the United States it has been held that when a corporation purchases its own shares in order to give the directors majority control by reducing the total number of shares outstanding, the purchase is a breach of the directors' fiduciary duty and a wilful disregard of the rights of other shareholders based primarily on the reasoning that retention of control was not a proper purpose for which funds of the corporation could be spent. ${ }^{205}$ However: ${ }^{206}$

An exception to these decisions has been created in situations where the purchase of shares is justified by some other corporate purpose such as the need to reduce outstanding shares, even though the purchase may in fact solidify management's control. This distinction becomes blurred when the directors cause the corporation to purchase its stock because they believe that their continued control will benefit the corporation. If desire to retain control bars the purchase, management will be unable to head off a bid for control by unsavory insurgents. On the other hand, if the directors are permitted to use corporate funds to make such stock purchases, their ability to secure their own position against shareholder attack will be significantly increased.

14: Hornstein, supra, n. 17 at 615. In supporting the English position, Gore-Browne on Companies, supra. n. 34 at 278 provides that the rule in Trevor $v$. Whitowrth has the dual purpose of maintenance of capital for the protection of creditors and prevention of the directors strengthening their position in the company through their use of voting rights attached to shares purchased and held by the company.

199 American Railway Frog Co. v. Haven (1869) 101 Mass. 398; Ex Parte Holmes (1826) 5 Cow. (N.Y.) 426. Nor may the stock be voted if held in the name of a trustee for the benefit of the corporation: Ex Parte Holmes, supra; or if it is held by the corporation as pledgee: Brester v. Hartley (1869) 37 Cal. 15.

2w Levy, supra, n. 5 at 6: Nernmers, supra, n. 113 at 166. lacobucci, supra, n. 51 at 120 explains: "For example, if the directors as a group controlled $45 \%$ of the outstanding voting shares, they could, by causing the corporation to purchase $11 \%$, end up having an obsolute majority of the voting shares."

201 Nussbaum, supra, n. 66 at 986. Zilber, supra, n. 158 at 328, in speaking of the problem of retention of control by means of corporate share purchases, provides: "A greater number of shares must be purchased by the corporation in order for management to retain control than if management purchased the shares personally [because the shares purchased by the corporation do not carry voting rights]. However, those in control benefit by such corporate purchase by not having to expend any of their own funds. Not surprisingly the courts have frowned on this procedure."

202 Gower, supra, n. 24 at 112.

$20: 3$ Note, supra, n. 177 at 308.

204 Dodd, supra, n. 67 at $697-698$. This was the subsidiary reason for prohibiting a corporation from purchasing its own shares laid down by Lord Macnaghten in Trevor v. Whitworth, supra, n. 1 at 435.

zus Anderson v. Albert \& T. M. Anderson Mfg. Co. (1950) 325 Mass. 343.

zon Note, supra, n. 177 at $309-310$. 
This reasoning led some American courts to later hold that retention of control might be a proper corporate purchase if, in the absence of fraud or unfairness, the reason for purchasing the shares was to eliminate a stockholder whose policy was at odds with that of the current management. 207

Purchasing its own shares may permit a corporation to confer a preferential benefit on certain shareholders by having only their shares purchased or purchased at preferential prices. Such purchases may, for example, permit influential insiders to withdraw their contribution to a venture in which they have lost confidence or when no other market exists for their shares.208 In addition, what may be termed a "preferential liquidation" is achieved by the corporation's buying out favored parties when the ultimate purpose is to liquidate and it is realized that liquidation will result in less than par repayments for all the shareholders if they are to be paid off at the same time.209

More specifically, a lack of equality of treatment may arise among different classes of shareholders or among shareholders of the same class. In the former case, a corporation's purchase of its own shares may be used to undermine the equity or margin of safety in back of preferred shares, decrease assets and surplus and thereby defeat the reasonable expectations of preferred shareholders, who are long-term investors in corporate enterprises as to future dividends and also those in arrears. ${ }^{210}$

Inequality among shareholders of the same class can arise since such purchases are neither a device for putting income pro-rata into the hands of stockholders on a continuing basis, nor a device to convey signals with respect to future earnings. ${ }^{211}$ Unequal treatment can arise, for example, where a premium is paid to a large shareholder of one class of shares because of the control element arising from his block of shares; where stock is purchased out of capital surplus attributed to other shares of the same class; or where liquid assets are paid out to selling shareholders, thereby leaving operating assets of doubtful value for the remaining shareholders. ${ }^{212}$

Even if the purchases are not made slectively, to preserve control or to benefit particular sellers, questions are raised by the impact of the purchases on the shareholders. Sellers may be wronged if the purchase is made at a price which is "too low", in the sense that if the seller had all the information which the buyer had he would not have sold at so

${ }^{207}$ Martin v. American Potash \& Chem. Co. (1952) 33 Del. Ch. 234; Kors v. Carey (1960) 158 A. (2d) B.C. The property of this position will be examined in that part of the paper dealing with possible safeguards.

zus Levy, supra, n. 5 at 7.

${ }^{209}$ Nemmers, supra, n. 113 at 166. Charlesworth's Company Law (9th ed.) edited by T. E. Cain, (1968) at 144 supports the English rule on the basis that it ensures that any reduction of capital is equitable as between the shareholders of a corporation. In effect, it prevents the possibility of the directors of a company from showing a preference to one shareholder or group of shareholders (which may or may not include one or more of the directors themselves) by having the company purchase only their shares.

2so Ballantine, supra, n. 7 at 609.

211 Brudney and Chirelstein, supra, n. 122 at 460.

212 Zilber, supra, n. 158 at 328 . Stevens, Corporations (1949) at 278 comments on the position of shareholders of the same class: "IT]he agreement between them contemplates equal distribution of corporate losses and equal distribution of corporate assets, after the satisfaction of creditors. A shareholder may protest if the corporate purchase of the shares of another member will have the effect of increasing the burden of corporate liability of those who remain shareholders, for the fund applicable to corporate debts has been reduced by the amount of the purchase price. The corollary of this is that the pro rata share which each member will receive upon dissolution will be less than the amount which has been paid to the member whose shares have been purchased. This objection would be valid whether the purchase were made out of capital or out of surplus. In other words, each shareholder has a right to insist that, if the shares of any other member are purchased by the corporation, there will be a breach of the contract between the members, unless the price paid does not exceed that amount which the others would receive if the corporation were dissolved." 
low a price. ${ }^{213}$ The shareholder who contemplates selling his shares to the corporation or to another party may, like the investor who contemplates becoming a shareholder, be injured when management possesses superior knowledge about the present and potential value of the shares. ${ }^{214}$ If non-sellers are advantaged when a share purchase is made at a price which is "too low", they are correspondingly disadvantaged when the purchase is made at "too high" a price, in the sense that the company paid more than the true worth of the shares, since the value of the remainder is thus dispreportionately diluted.215

In the United States it has been held that new issues of stock must be offered to existing shareholders, pari passu, before outsiders are given the opportunity to subscribe. The purpose was to protect their rateable control of the enterprise and their rights in undivided surplus. But it has generally been held that shareholders have no similar right of preemption in shares reacquired by the corporation, because upon its reissue their original rateable control is not altered. ${ }^{216}$ The result, of course, is that the management can cause the corporation to purchase stock and then reissue it to sympathetic parties and thus avoid the sometimes annoying right of pre-emption. This can lead to abuse where the management is seeking to reissue stock without giving minority stockholders an opportunity to buy and thus prevent their growth within the company.

\section{The General Investing Public}

Finally, the general investing public is subject to potential abuse where a listed company is entrusted with the power to purchase its own shares. In the first place, reacquired stock has been the time-honored device for marketing "low-grade" securities in the United States. In order to avoid the legal restriction that original issues must not be issued for less than their par value, a common modus operandi is to issue original issues to promoters in over-payment for their services rendered or property transferred to the corporation. These shares are then donated back to the corporation by the promoters. There is no restriction on the minimum price that these reacquired shares may be reissued at, since the interests of creditors, stockholders and potential investors are presumed to be protected if the stated price is paid for the stock originally, and consequently such stock may be sold for less than its par value. The shares are sold to the public for what they will bring in order to gain cash for working capital and the unsuspecting investor (as well as the potential creditor) may falsely rely on the stated capital figure on the corporation's balance sheet. ${ }^{217}$

Secondly, a corporation's purchase of its own shares may be made for purposes of market speculation or even market manipulation. By creating a "bull" market through extensive purchases of its own stock, a corporation sets an artificial value on its shares. ${ }^{218}$ Deliberate over-

\footnotetext{
21:i Brudney and Chirelstein, supra, n. 122 at 461.

214 Note, supra, n. 157 at 307 and further at 310: "There may be fraudulent purposes, too, as when shares are repurchased with knowledge that the unreasonably low price will enhance the liquidation share of the remaining shareholders. Shareholders who sell directly to the corporation, shareholders who sell on the open market at the time the corporation is purchasing, and buyers who purchase at the time of the repurchases may be damaged because important facts are missrepresented or withheld from them."

215 Gower, supra, n. 24 at 112.

${ }^{216}$ Frey, Shareholders' Pre-emptive Rights, (1929) 38 Yale L.J. 563 at 580. There is no corresponding inherent right of pre-emption in Canada: Harris v. Sumner, 39 N.B.R. 204.

217 Levy, supra, n. 5 at 5-6; Counihan, supra, n. 138 at 142.

218 Levy, supra, n. 5 at 8.
} 
payments for purchased shares may be made so as to raise the market price of the corporation's stock so that, for example, it may more profitably be used as currency to purchase new assets, or to induce conversion of the convertible debt. ${ }^{219}$ Brudney and Chirelstein state that whenever purchases are made either (1) to increase the market price of the stock or (2) merely to "peg" it at current levels, substantial questions exist with respect to the propriety of such expenditure of corporate funds: ${ }^{220}$

(a) At best, management seeks to affect the market price because it believes the stock
is 'undervalued'. Do such purchases by the corporation, even if disclosed in advance
to the public, inject into the market an artificiality which detracts from the role of the
market as the register of equilibrium between a willing seller and a willing buyer? Is
management's judgment-whether as a faithful fiduciary or as an errant fiduciary-a
'legitimate' pricing factor comparable to the judgments of buyers and sellers seeking to
advance their economic interests as investors? Is management's self-interest apt to
inject a bias in the repurchase program which should be irrelevant to the market's
pricing mechanism-e.g., to keep the price higher than the stock's value justified in
order to win the approval of stockholders? (b) If the disparity between management's judgment as to the value of the stock and the market's evaluation of the stock is to be cured, is it more appropriate to use corporate cash to affect the price than to disclose the information which will bring the price into line? On the other hand, are there limits to the disclosure which is permissible in order to bring the price of the stock up to management's judgment of an appropriate price?

(c) If, notwithstanding the fullest permissible disclosure, the market still evaluates the stock at less than management does, can management ever (even assuming no interest in diversion of values for its own benefit) properly use corporate assets to favor one set of stockholders (the non-sellers) over another (the sellers)?

The creation of an artificial market situation by a corporation purchasing its own shares causes a false picture to be presented to the general investing public as to corporate condition. ${ }^{221}$ As one commentator expresses it: ${ }^{222}$

The public at large is interested in true quotations and the market degenerates by a company's dealing in its own stock. A corporation is even less a proper buyer of its own shares than a factory of its own products. Its coming into the market ordinarily suggests that something is wrong, that the corporation purchases because the public does not. Hence the trend to have the purchases executed by third persons. Without the company's intervention quotations presumably would have been lower, expressing the public's real opinion of the shares. Offers of stock may be caused by lack of confidence in the prospects or in the management of the company. 'Support of the market' then means suppression of a warning sign which might result in preventive or curative measures.

Insiders of listed companies can cause the company to purchase its own shares, thereby artificially raising the market price, and then sell their own shares at the higher price. And, although ". . . it is true that the majority American rule is hemmed by the usual fraud and fiduciary qualifications, .... these may be small comfort when the burden of showing violations is on the plaintiff stockholder, especially where the corporation is large and the stockholder small."223

ay Brudney and Chirelstein, supra, n. 122 at 463.

2*o Supra, n. 122 at $463-464$.

221 Counihan, supra, n. 138 at 142.

222 Nussbaum, supra, n. 66 at 988; the valuation of treasury stock resting on artificially managed quotations is in itself misleading to the general investing public. Levy, supra, $n$. 5 at $26-27$ provides that people who buy shares on the market relying on the company's earnings are likely to be misled into believing that the profits were realized from the primary activity of the company and that they were indicative of a healthy state of affairs.

2y: Nemmers, supra, n. 133 at 167 . Nussbaum, supra, n. 66 at $989-990$ states: "Even a boom may be manufactured by a company's purchase of ito own shares. . . . The boom stock price may be used to get higher loans upon 
Finally, entrusting corporations with the power to purchase their own shares can give rise to deceptive accounting practices with respect to the reacquired shares. The true effect of such purchases as reducing surplus or impairing capital may be concealed or covered up. ${ }^{224}$ However, such potential abuse was early recognized and accepted accounting procedures have removed much of the deceptiveness:225

There is voluminous accountancy literature which discusses whether treasury stock should be shown as an asset, deduction from capital stock, or deduction from surplus. Accountants in the great majority are agreed that it should not be shown as an asset. It definitely is not an asset on which creditors or shareholders can realize. It is a mere bookkeeping device to balance the two sides of the accounting equation. Experienced balance-sheet readers will cross it off if it is listed as an asset and deduct an equal amount from the liability side (which may leave a negative surplus or loss). It is subject to the objection which will be presently advanced against deduction from capital stock, namely, that it leaves the earned surplus account unchanged.

A variant of the system of carrying treasury stock as an asset at cost exists. The variant is to carry the stock at par as an asset and to credit a surplus account (usually called capital surplus) with the difference between the cost and par if the stock was purchased below par or to debit the same account if the purchase was above par. This system, like the asset at cost system, leaves the earned surplus item unchanged (at least as to the cost of the shares). . . .

Deduction from capital stock is just as deceptive and has the condemnation of accountants, although there is some debate about the matter. . . .226

It has been definitely accepted as the best opinion of the majority of the accounting profession that treasury stock should be cumulatively listed as a deduction from surplus.

\section{POSSIBLE LEGISLATIVE SAFEGUARDS}

\section{A. Denial of a General Power to Purchase}

\section{The first and most obvious possible safeguard is to deny corporations}

treasury stock, hence means for further purchases . . .; under the American rule, companies may sell their own shares short. Irrespective of whether the company is a bull or a bear, the directors are in a situation whereby they can easily profit from its speculation by private dealings in company stock."

224 Ballantine, supra, n. 7 at 609.

225 Nernmers, supra, n. 113 at 183-185. The details of accounting procedure will be examined in more detail in that part of the paper dealing with possible safeguards.

230 The deception (which also exists in the asset theory) is best known by an illustration rather than by an abstract discussion. Assume a surplus of $\$ 10,000$. This surplus can be used over and over again to make purchases as long as no single purchase exceds $\$ 10,000$ (or the amount of the surplus) and this is because each time such a purchase was made it would result in a decreased sum for the net capital (i.e., the legal capital stock less the treasury shares) in the exact amount of the purchase which would "unbalance" the liability side of the balance sheet and give rise to an automatic increase in the surplus account in the exact amount of the purchase (assuming that the surplus account has been charged in the first place with the purchase as a deduction). The net result is that we have decreased an asset (usually cash) and decreased a liability (ex hypothesi the net capital stock account) and have not affected the surplus account (assuming that the stock was bought at par). The following simplified balance sheets show this:

Before purchase

Cash

$\$ 100,000$

$\$ 100,000$

After purchase of $\$ 10,000$ stock at par with cash

Cash

\section{$\$ 90,000 \quad$ Capital Stock \\ Surplus}

$\begin{array}{r}\$ 90,000 \\ 10,000 \\ \hline 100,000\end{array}$

$\$ 80,000$

10,000

$\$ 90,000$

If stock is bought below par, there will be an increase and if it is bought above par, a decrease in surplus. Nussbaum, supra, n. 66 at 989 provides: "Another example of the ambiguous and misleading character of treasury stock is to be found in the fact that it amy be manipulated in such a way that a book profit resulto on both a rising and a falling market. If the market is rising, the management may resell the shares above the purchase price; on a dropping market, the stock may be cancelled, and thus the issued capital item on the liabilities side will be reduced to the amount of the face value of the shares cancelled (or the credited value when the shares are without par value). Here a book profit equal to the difference between the par value and the purchasing price (if it was below par) will result. It is clear that book profits arising from the purchase by a corporation of its own shares should be shown separately from earned surplus. At the present time, however, loose methods of accounting for this item are generally prevalent. Moreover, although such distribution should be declared illegal, dividends are frequently declared on treasury stock. All these tactics are apt to veil a poor business condition." 
the general power to purchase their own shares except in special and narrowly-defined circumstances. Advocates of this view argue that the potential abuse does not warrant the enactment of legislation entrusting corporations with a general power to purchase their own shares especially where Canadian corporations do not require such a power since reasonable alternative methods exist to achieve the same results as could be achieved under share purchases.

For example, it has been argued that, with the exception of several United States-based companies, most Canadian corporations are either unaware of the practice of corporate stock purchases or feel it is unnecessary for their present business practice. Such was the finding of a survey of the Investment Dealers Association of Canada227 and compares very closely to the Report of the Jenkins Committee ${ }^{228}$ in Great Britain which stated that:

... we have received no evidence that British companies need this power and the relatively few witnesses who offered any evidence on this matter were almost unanimous in opposing the introduction of a general power for companies to buy their own shares.

Thus, it is argued that since this is the situation the effort of introducing a general power of purchase together with concurrent safeguards is unwarranted in light of the probability that little use would be made of such a procedure.

Even if business demands warrant such a power, it is argued that the potential for abuse outweighs its business expediency. Professor Nussbaum wrote in 1935:229

Professor Wormser ${ }^{230}$ in his plea for the majority rule indicates that the underlying reason for the American doctrine is the feeling on the part of most American courts that the English doctrine is far too narrow and rigid and 'unduly ignores customary business demands.'231 Those demands do indeed exist and they have, in this country as elsewhere, influenced courts and legislatures.

To be sure, purchase of the corporation's own shares, looked upon from the angle of the management, represent a device of the highest expediency which certainly must have been applied successfully in many cases. Stabilization of the market may sometimes have been obtained; profits may have been gathered by corporations from speculative operations in their own shares; idle funds may have been temporarily well invested; mergers and combinations may have been facilitated by the existence of treasury stock given to shareholders of a merged corporation or exchanged between combined corporations, thus dispensing with an increase of capital. These facilities are of course attractive to directors. Yet attractive also in the opportunity for shifting and manipulating corporate values afforded by the device. Consciously or subconsciously the feeling that there is a certain 'beneficial' ambiguity in treasury stock is probably behind the 'customary business demands' which have swelled up so alarmingly within the last few years. It is not for the law simply to yield to them. History has shown that the purchasing practice involves serious dangers which may result in disaster. At the same time the frequency of ambiguous situations created by the practice produces an unsound business atmosphere which should be clarified by a law which seeks to preserve its essential function of working for high business standards.

A stronger argument ${ }^{232}$ supporting the denial of a general power to

22: Interim Brief of the Investment Dealers Association of Canada (1967) presented to the Lawrence Committee. See, generally, Leblovic, supra, n. 4 at 67.68.

226 Supra, n. 65, para. 168. This was also the conclusion reached by Iacobucci, supra, n. 51 at 120.121: "We adopt the conciusion of the Jenkins Committee, which also rejected the adoption of the power, in saying we do not believe the case for companies needing the power has been shown to outweigh the serious disadvantages which exist."

229 Supra, n. 66 at $990-991$.

zuv Wormser, The Power of a Corporation to Acquire Its Own Stock, (1914-15) 24 Yale L..J. 177.

2:31 Id. at 183.

2s: It has sometimes been argued that it is theoretically anomalous for a corporation to be a shareholder of itself and that for this very reason acquisition of its own stock must be unlawful. It is difficult to abide by this 
purchase is that the purpose for which such a power may be used can be achieved by reasonably alternative methods which, although less expedient, do not give rise to the same potential abuse: ${ }^{233}$

The mere possibility of abuse is not of itself an argument against permitting a practice which may be useful. But in the realm of corporation finance and management, the readiness with which a power may be and is being abused may be a valid reason for its abolition, especially when . . . the valid functions it serves may be performed by less volatile agencies.

For example, it has been argued ${ }^{234}$ that employee incentive and benefit plans can be alternatively arranged, as indeed they are at present, by procuring the needed shares from authorized but unissued stock, or by increasing the corporation's capital stock. If the policy of the corporation is to have the employee cease to be a shareholder when his employment ceases, the original sale to him of the stock can be with an option in the remaining shareholders or in some of them to repurchase. These latter shareholders can then resell those same shares to the new employees who replace the retiring ones. Such a scheme has been held in the United States not to create an illegal restraint on alienation. ${ }^{235}$ Alternatively, an approach more commonly used in England and Canada is to have a block of the corporation's shares held by a trustee with the employees as beneficiaries of the trust for as long as their employment continues. Even the prohibitionists note, however, that if the suggested method for such plans is too cumbersome, the corporation's purchase of its own shares might be specifically premitted by statute as a "special circumstance" without conceding the power generally.

Where a shareholder is retiring from a small private corporation so as to settle internal dissension, for example, it is argued that it is not unjust to compel the remaining shareholders to purchase the shares as individuals to gain the unopposed control they seek to formally reduce the capital of the corporation. Although obviously more expedient, the power in a corporation to purchase its own shares for this purpose is not essential. Nor is the inclusion of a repurchase agreement a sufficiently justifiable purpose to warrant the granting of the broad general power to purchase.

In Canada, the Canadian Institute of Chartered Accountants (CICA) was also strongly opposed to the granting of such a power in corporations. In a brief submitted in relation to the federal proposals, they stated:236

The right of a corporation to acquire its own shares through purchase for other than very limited purposes is a new departure in Canadian law. The only jurisdiction providing such a right (Ontario) has done so only recently and the right so provided has, perhaps for tax reasons, been very little used to date. The reasons put forward in Ontario for providing such a right are to us neither clear nor compelling and we do not believe that a sufficient investigation of the advantages and problems of the purchase by a corporation of its own shares has yet been made in Canada. The commentary to the proposals does not deal with why the right of a corporation to purchase its own shares is a desirable thing but talks rather in terms of how the possible abuses of such

\footnotetext{
argument, however, and yet recognize the existence of exceptions to the strict prohibitive English rule in Thevor v. Whitworth. Nussbaum, supra, n. 66 at 991 , states that although this argument certainly goes too far, "it is true that the concept of a corporation being its own shareholder is, because of its over-artificial character, unsound in its inception and productive of numerous and highly undesirable twilight phenomena." 
a privilege might be controlled. A brief and informal consideration of the uses to which this privilege appears to have been put in the United States and possible alternative methods of achieving the legitimate objectives which have been sought would seem worthwhile. The following purposes may be sought in repurchasing shares:

1. A return of unnecessary capital to shareholders in such a way that shareholders who wish to reduce their holdings may do so while those who wish to retain their positions may also do so. This same purpose can be achieved through a formal reduction with the shareholders subsequently buying or selling shares in the market or privately to re-establish their desired positions. However, the formal reduction procedures can be a nuisance as discussed further below.

2. The improvement of the corporation's debt/equity ratio or an increase in earnings per share by reducing the number of shares outstanding. These are really variations on the first purpose in that they represent reductions of capital without the necessity of shareholder and creditor approvals.

3. To support or increase the market price of the corporation's shares. This is, of course, not a legitimate use of the right and a purpose which must be guarded against.

4. To acquire shares to be used in employee stock option plans, corporate mergers, payment of stock dividends, or conversion of convertible debt issues. To the best of our knowledge, Canadian corporations have seldom experienced difficulty in using previously unissued shares for these purposes.

5. To improve the position of controlling shareholders by enhancing the value of their shares, strengthening their voting position or assisting them in liquidating a portion of their holdings. Again, these are not legitimate purposes.

6. As a technique for fighting a take-over bid. This is at best a 'neutral' objective since there can be no presumption that the take-over bid is detrimental to the shareholders of the company.

\section{And further:237}

The undesirable purposes in the above list will, in our opinion, prove difficult to control. ... On the other hand, the legitimate purposes in the above list can generally be met other than through the purchase of shares. Formal reductions of capital or reverse splits coupled with dividend distributions will usually achieve these purposes.

Generally, the argument that reasonable alternatives exist for accomplishing the same results attainable under a general power in a corporation to purchase its own shares can be used for almost all of the reasons for purchases examined earlier and for those that require such a power, they can be enacted as specific statutory exceptions or as extensions of a corporation's statutory redemption powers thus avoiding the potential abuses that the granting of a general power could give rise to. 238

The CICA went one step further and, recognizing the current formal reduction of capital procedures are somewhat time consuming and expensive, recommended the adoption of a less formal method of reducing capital so as to provide a compromise between the potential abuses of a general power to purchase and the current procedures: ${ }^{239}$

The formal procedures for reduction of capital are somewhat time consuming and expensive. Shareholder and creditor approval is necessary. Neither the present Act nor the Proposals make any provision for a reduction of capital through a pro rata distribution to shareholders other than through the rather lengthy formal reduction procedures. A less formal method for reduction of capital might be provided whereby the reduction was carried out by the directors without the necessity of shareholder or creditor approval, subject to a solvency test and to liability by the directors for an improper distribution. This amounts to the ability to make a distribution in the form of a pro rata reduction of capital under the same rules as apply to the payment of

237 Id. at 5-4.

238 This was the argument of the British Columbia branch of the Canadian Bar Association in their Comments on Proposed B.C. Companies Act (Bill 66) (1972) at 114.

230 CICA, supra, n. 236 at 5-4. 
dividends. There are undoubtedly many corporations where the directors would be quite willing to accept such a liability because it is abundantly clear that any solvency test can be amply met. This might provide a compromise between the possible abuses of repurchase provisions and the expense and delay of the formal proceedings.

There are, however, equally strong arguments in favour of entrusting corporations with a general power to purchase their own shares. Proponents of this view argue that the advantages of such a power outweigh any disadvantages since adequate safeguards can be enacted to avoid potential abuse. As one commentator expressed it: ${ }^{240}$

If abuse results, the abuse should be stifled. But the corporation should not be unduly hampered by laying down the arbitrary rule of non-acquisition of its own shares, irrespective of good or bad purpose, object and result.

In support of their argument that adequate safeguards can be enacted, the proponents of this view rely on both American and Canadian experience with the concept. The Lawrence Report stated:241

Over fifty years of experience in Ontario with redeemable preference shares and the experience in the United States with the right to purchase common shares would indicate that, provided adequate safeguards exist, there need be no apprehension concerning the protection of the rights of creditors and others in permitting companies to purchase their shares.

\section{Professor Kessler states: ${ }^{242}$}

It is probably safe to conclude initially, however, from the many instances in which American corporations have exercised the power in the past, with judicial approbation and without shockingly harmful effects upon creditors and shareholders, that the English rule of absolute disqualification should be rejected. Generally speaking share purchases by a corporation should be allowed. Clearly the corporation has an 'interest' in making such purchases, at least in the situations delineated above. The only question then becomes one of qualifications upon the exercise of the right. This problem, as is the case with most legal investigations, reduces itself to an evaluation of competing interests (a choice of harmful vs. beneficial effects to each group) in a trichotomy which also includes creditors and shareholders of the corporation.

Secondly, it is argued that a general power to purchase is necessary in Canada's expanding and dynamic corporate setting and to deny an adequately safeguarded right of purchase ". . . would unduly hamper corporate activity and usefulness and the serviceability of the private corporation as to a type of business organization."243 The argument that there is no demand for a power in England, which was considered a regrettable illustration of the conservatism of the English legal and commercial world, ${ }^{244}$ would seem to be even less forceful in Alberta's booming economy. The current statutory exceptions or any extensions thereof are insufficient to satisfy the need for a general purchase power: ${ }^{245}$

240 Wormser, supra, n. 230 at 181 . Indeed, even the Jenkins Committee, supra, n. 65 at para. 168 agreed: "In our view, if the Companies Act were amended to give a limited company a general power to buy its own shares it would be necessary to introduce stringent safeguards to protect both creditors and shareholders. We think it would be possible to devise effective safeguards and we do not think they need to be unduly complicated."

24 Supra, n. 180 at 35 . See also Leblovic, supra, n. 4 at 76: "American theory and practice has been outlined to show that the competing interests of the creditor and the company may be properly balanced by several comprehensive types of stock purchase legislation, which are sufficiently liberal to allow the company to enjoy the benefits of redemption, while containing safeguards to prevent the corporation from prejudicing the interests of third parties."

24: Supra, n. 120 at 651.

24. Wormser, supra, n. 230 at 188. The need for a general power to purchase for Alberta companies was stressed in a paper presented to the Business Development and Tourism department of the Alberta government by $R$. McDaniel. In his presentation Mr. McDaniel emphasized that immediate action to allow Alberta companies to purchase their own shares could effect significant gains in control of a number of smaller oil and gas companies by Albertans (and Canadians).

21, Gower, supra, n. 24 at 114.

2ts Leblovic, supra, n. 4 at 64. 
Though one can regard the above statutory reforms as evidence a movement away from Trevor v. Whitworth, it has been argued that it is unnecessary to go any further than what the law permits today-the preference share giving the right of redemption, the reduction of capital permitting a narrowing of the equity base to meet business contingencies, and the other provisions meeting minor requirements as they arise. In theory, such argument is convincing, but practice has proved it without merit. In the first place, certain corporations finding existing legislation too restrictive and desiring more extensive redemption possibilities, have conferred on their preference shares some technical or illusory advantage over the common shares-thus by subterfuge evading the common law restrictions. Secondly, reduction of capital is a relatively slow process, requiring major reorganization of the company and really failing to meet the need of the corporation which wishes to distribute funds to its shareholders at a time of profit and not when its business fortunes dictate a reduction in capital. And thirdly, to look ahead, these provisions are insufficient and too bound-up by red-tape to meet many of the desired and commercially valid ends which may be so easily achieved by a stock redemption provision.

Thus it is far easier to view these statutory reforms, not as ends, but merely as signposts showing that, since in some respects what is barred by the common law is either being achieved by some clumsy indirect method or is commercially desirable and not attainable, there seems little logic in not introducing a comprehensive stock purchase technique which would allow these same ends, but permit a procedure which is more in line with modern business practice.

Further, the argument that little use would probably be made of such a power seems to have little merit. In addition to the acknowledged fact that some corporations do, in fact, desire this reform as they are already attempting to garner its advantages under the present unsophisticated provisions, the mere lethargy of some Canadian companies in using the power does not destroy its positive attributes but merely shows that such companies are as yet unaware of its merits and advantages. Its present dormancy does not alter the fact that its introduction may bring about its widespread utilization. ${ }^{246}$

Thirdly, it is argued that although alternative means are available to achieve basically some of the same objectives as under a share purchase power, they are neither as expedient nor do they always produce the desired results a share purchase does such as, for example, prevention of dilution of the corporation's equity base. Leblovic explains the unsatisfactory present position as follows: ${ }^{247}$

The first major objection is ... that in Canada, with existing preference share privileges and the possibility of capital reduction through the use of supplementary letters patent, there is no need for an extension of such rights since for most purposes they are available in these procedures. It is further claimed that the value of liberalization is not warranted in face of the possible abuses which may be forthcoming from their institution.

In answer to these objections it may be said that present procedures do not, in fact, extend to Canadian corporations and shareholders the advantages which their American counterparts receive from their redemption powers. It may be added that the lack of such comparable possibilities has led to a perversion of these existent procedures so that they may be technically used to achieve the ends of stock repurchase. In light of these findings it seems ridiculous to contend that the disadvantages of redemption far outweigh its possible advantages. What is occurring now is that those companies that desire the advantages in fact get them by technical subterfuge, thus still being able to abuse the powers with little or no statutory protection to counter them. If a de jure recognition of these practices were implemented in the form of stock-purchase legislation, concurrent safeguards and prohibitions would be instituted to protect the creditors and shareholders. We have now the worst of both worlds!

He adds further that those dissenters who maintain that existing

246 Id. at 68.

247 Id. at 67. 
procedures in Canada adequately meet all possible uses of a corporation's purchase of its own stock do not realize the myriad and varied business opportunities that this type of transaction can bring. ${ }^{248}$

Fourthly, it is argued that the rationale for the rule in Trevor v. Whitworth has disappeared in that the stated capital of a corporation is no longer a practical source of protection for creditors and shareholders. The weakness of the rule is pointed up by an analysis made by Professor Gower: ${ }^{249}$

(1) There is no requirement that shares must be of a reasonable nominal value and that part of this value must be left uncalled. Hence the practice is to have shares of low denomination issued fully paid on allotment. Uncalled capital, which was envisaged as the main protection of the creditor, has virtually disappeared, thus removing any element of personal credit from the concept of capital.

(2) There is equally no requirement of a minimum paid up capital. Hence the rules which seek to secure the maintenance of paid up capital are valueless except in the case of large public companies. With private companies having small issued capital no reliance whatever can be placed on the capital as a guarantee fund. Indeed, this is recognized in practice, and such companies are treated much as partnerships, the members being required personally to guarantee any formal credit facilities. Even in the case of a public company a yardstick based on the nominal value of money is unrealistic in times of inflation.

(3) Since shares may be issued for a consideration other than cash, and since the courts will not normally investigate the adequacy of the consideration, there is not even any assurance that the company ever received assets equivalent to the nominal value of its issued capital.

(4) Even if the capital has been raised, the law cannot ensure that it is not lost in subsequent trading; at the most it can prevent its being repaid to the members.

Even though capital is almost invariably low and not absolutely inviolate, the principle remains. Professor Kessler argues: ${ }^{250}$

Even if the concept of capital as a 'trust fund' for the creditors of a corporation be rejected, it is still well-established that one of the basic reasons behind the requirement is to provide for sufficient corporate assets to discharge corporate obligations. A subsidiary function of capital is the protection of senior shareholders of a corporation by granting them some assurance that there will be sufficient corporate assets available to discharge their liquidation preferences. The requirement also inures ultimately to the benefit of all shareholders, since it is at least a limited guarantee against improvident distributions of their contributions and resultant financial collapse of the corporation.

Although the introduction of no-par value stock and 'liberal' allowance of charter amendments reducing capital have created serious restrictions upon the effectiveness of the device, the salutary purpose of the requirement remains unaltered.

It is obvious that whatever reduces the sum of liquid (or liquifiable) corporate assets reduces the fund on which creditors and shareholders may rely for satisfaction of their respective debts or equity claims.

... It is therefore clear that capital sets at most a minimal requirement for the full satisfaction of obligations to creditors and shareholders. No matter how defined, any 'impairment of capital', of diminution of this fund, is undesirable from the point of view of creditors and all shareholders (except those who receive preferential treatment in the disposition of this 'capital').

In practice, however, the situation may well be different: ${ }^{251}$

Whether creditors actually do rely on capital or not is a mooted point. Certainly enlightened and large creditors do, if their requirement for personal guaranties of significant obligations in corporations which they suspect are undercapitalized is any indication (as has been the author's experience in the case of newly organized small

24s Id. at 73 .

«9 Supra, n. 24 at 122-123.

230 Supra, n. 120 at 651-653.

2st Id. at 662. See also Wormser, supra, n. 230 at 180. 
corporations making large loans from banks). Whether they actually do rely, however, seems less significant than whether they have the 'right' to so rely, a right which is not too high a price for businessmen to pay for the privilege of limited liability. On the other hand, while they might also prefer to have earned surplus at their beck and call, under traditional legal theory they have no such right to rely on this profit item as a guarantee for their payment. The proprietor of the corner stationery store who sells the corporation one box of pencils may not know or care about the difference between corporate and capital surplus. Since the legal distinctions have been in force for so long, however, it is not unreasonable to assume that larger creditors will apprise themselves of the capital-surplus situation of a corporation and guide themselves accordingly.

Finally, the response of the drafters of the federal proposals to the CICA's recommendation that a general purchase power not be allowed suggests a pragmatic reason for its adoption:

The lawyers unanimously want to see corporations empowered ... to purchase their own shares. If they cannot obtain it under the federal corporation law, they will simply incorporate under the Ontario law or under another provincial law that permits such purchase.

\section{B. Special Circumstances}

Even the proponents of the view that corporations should not be entrusted with a general power to purchase their own shares agree that there should be a limited power of purchase in those special circumstances where the potential abuse, if any, is outweighed by corporate convenience. These special circumstances can generally be categorized as follows: (i) compromising corporate claims, (ii) dissenting shareholders, (iii) elimination of fractional shares, and, perhaps, (iv) employee incentive and benefit plans. ${ }^{252}$ Purchases seeking the accomplishments of these ends are normally allowed out of any surplus or stated capital of the company. However, even they are usually forbidden where the purchase if at the time of the purchase, or before the consummation thereof, the corporation is or would be rendered insolvent thereby and thus unable to satisfy its debts and liabilities and they became due.

\section{Compromising Indebtedness to the Corporation}

Professor Kessler ${ }^{253}$ states that a corporation is normally allowed to accept its shares in compromise of a claim which it holds, even though this works a technical impairment of capital. As Stevens states:254

Even though such a transaction results in the cancellation of a debt due the corporation in return for the shares, it is a bona fide business transaction, and, because it saves the corporation from greater loss, cannot be complained of by creditors.

Normally such compromises, even if they necessitate small payments by the corporation to the debtor where the value of the shares are in excess of the indebtedness, are unexceptionable. Abuses are, however, possible. Although loans to corporate insiders are often forbidden by statute in the United States, ${ }^{255}$ "sales" to such insiders are not. Insiders

252 Some American authors (Kessler, supra, n. 120 at 653-656; Henn, supra, n. 127 at 686; Ballantine, supra, n. ? at 696) include redeemable shares in this classification as well. Redemption is a separate topic, however, and is beyond the scope of this paper.

253 Supra, n. 120 at 657.

254 Supra, n. 212 at 278. Pollis, supra, n. 131 at 423 provides: "There is little opportunity for abuse here, for the shares acquired, generally, will constitute a superior and more definite asset than the consideration paid by the corporation."

25s But not in Alberta private companies: section 14 of the Companies Act. See also on this point in relation to the B.C. Act: Getz, supra, n. 45 at $17 \cdot 18$. 
might well make transfers to their friends of valuable corporate assets on credit, later "compromising" such debts for corporate stock on which they had placed an inflated value. Although the danger of such abuses is slight in the face of traditional rules of the directors' fiduciary obligations, and manifestly the harm to creditors (unless the "compromises" include large payments by the corporation) from the impairment of capital is offset by the dimunition in the corporation's dividend obligations, such compromises should be expressly required to be bona fide to ensure the adequate protection of creditors. ${ }^{256}$ This would ensure not only that the debt was bona fide but also that it was otherwise uncollectible.

\section{Dissenting Shareholders}

Creditors are technically harmed, through capital impairment, when capital is used to pay off dissenting shareholders who exercise their appraisal right. However, they may be harmed even more if a minority shareholder is allowed to "hold up" a corporation about to enter into a merger, consolidation, or advantageous sale of assets. ${ }^{257}$ Furthermore, a dissenting shareholder's right of dissent, accompanied by a further right to a valuation and purchase of his shares, is a fundamental importance in corporation law and the availability of the purchase out of surplus or capital gives it a practical and meaningful value. ${ }^{258}$

\section{Fractional Shares}

Where the purpose of a corporation's purchase of its own shares is to eliminate troublesome fractional shares, there will generally be no substantial effect upon the corporate structure since the number of shares to be purchased would be ordinarily small, and their retirement would have little impact upon the relative voting positions of the members of the class. ${ }^{259}$ Where the fractional shares have resulted from the corporation paying a stock dividend, the creditors' position has improved since the payment of such dividends means a transfer of surplus to capital. A slight reduction in this "bonus" capital to retire fractional shares should thus give the creditor no grounds for complaint. However, there is room for potential abuse as well.260 For example, if the statute does not prevent a corporation from issuing all of its stock in fractional shares is limited, their purchase by the corporation should only be allowed out of earned surplus. Furthermore, Professor Kessler ${ }^{261}$ argues that even if fractional shares are limited to those resulting from stock dividends, there would appear to be no valid reason for permitting them to be purchased out of capital, since no prudent corporation would declare a stock dividend which completely exhausted its surplus.

\section{Employee Incentive and Benefit Plans}

Some statutes specifically allow for purchase out of stated capital the shares of the corporation pursuant to an option or obligation to purchase from an employee or ex-employee. These provisions are based primarily

\footnotetext{
2s6 The CICA, supra, n. 236 at 5-3 agreed stating that although the settlement or compromise of a debt to the corporation appears to be on many occasions a legitimate purpose not easily achieved by other means, the privilege can be subject to abuse and hence safeguards in the form of director responsibility would be appropriate.

25: Kessler, supra, n. 120 at 658

258 Pollis, supra, n. 131 at 424.

259 Getz, supra, n. 45 at 17 .

${ }^{250}$ Kessler, supra, n. 120 at $659-660$.

261 Id. at 260.
} 
on the rationale that such a purchase is truly a "special circumstance". Professor Dodd explains: ${ }^{262}$

In view of the special circumstances under which the investment is made, the application of a rule of law limiting repurchase to cases in which the corporation has a sufficient surplus for that purpose will have unfortunate consequences for both parties, particularly for the employee-investor. The corporation's failure to earn a surplus may result in curtailment of its working force and in loss of the employee's job. If, in addition, his savings are frozen in non-dividend-paying and unmarketable shares which the corporation cannot legally buy from him despite its promise to do so, his plight is a serious one. The harshness of this result is accentuated if, as is sometimes the case, his original investment was made under a considerable amount of compulsion.

If we really want to promote, and not merely to tolerate, a type of share subscription which is advocated by its proponents largely for the very reason that it serves other purposes than that of contributing to corporate capital, it may well be that we should relieve this special type of shareholder from the full rigor of the rule which refuses to permit shareholders to withdraw any part of the corporate capital. Nevertheless, if such an exception is to be made, it should, at least in jurisdictions where the statute specifically forbids purchases that impair capital, be made by a special statutory provision rather than be a judge-made exception to the general rule. . . .

Finally, Professor Kessler notes that any statute empowering corporations to purchase their own shares in any of these extraordinary circumstances should require the exhaustion of surplus for such purchases before the capital account may be eaten into. "Clearly, if a corporation has a surplus, it should be required to utilize it completely before dipping into its capital, no matter how cogent may be the reasons for share reacquisitions." 263

There is no doubt that the decision whether to entrust corporations with a general power to purchase their own shares or to restrict such a power to specific and -narrowly-defined "special circumstances" is one of the most important ones in this area the formulators of the new legislation will have to make. It is important to realize that the greatest opposition to the granting of a general power to purchase in the United States developed in the 1930's when the majority common law rule was giving rise to abuse and the corporation statutes of the time were criticized as providing inadequate safeguards. Today, the authorities acknowledge the existence of the general power and deal with the intricacies of its expanding uses and the regulation of new potential abuses. Clearly the deciding factor is not the corporate necessity or desirability of the general power, for that, it is submitted, can be generally admitted, but is, rather, whether adequate safeguards can be enacted so as to protect creditors, shareholders and the general investing public from the potential abuse that can arise under a general power to purchase. To this question the writer now turns.

\section{Possible Safeguards Under a General Power to Purchase}

\section{Current Safeguards}

Assuming Alberta corporations were suddenly entrusted with a general power to purchase their own shares without any specific legislative safeguards, the law would still provide some protection to creditors, shareholders and the general investing public. For example, creditors and non-selling shareholders could found an action against the directors for fraud or deceit or breach of directors' fiduciary duties,

262 Dodd, supra, n. 67 at 716-717.

26:s Supra, n. 120 at 660. 
where an improper purchase was made to their resulting detriment. The interest of the shareholder who sells directly to the corporation is protected in two ways at common law: for affirmative misrepresentation by an action in deceit and for culpable silence by a theory of fiduciary relationship between the corporation and its shareholders (to be distinguished from the directors' duty of loyalty to the corporation). ${ }^{264}$

The power to reacquire shares, like other powers, is also subject to equitable limitations and there is power in a court of equity to restrain abuses of the practice. ${ }^{265}$ Good faith is essential and the reacquisition must be for the benefit of the corporation as a whole. A purchase would therefore be invalid if unfair or inequitable or oppressive to other shareholders or ". . . when it conflicts sharply with well-recognized and superior legal interests."266 Reissue of reacquired shares is also subject to the same equitable limitations and would not be tolerated where the consideration received is grossly inadequate or where the prime motive is to shift voting control within the enterprise.

However, these protections afford little effectiveness for two reasons. First, the definitions of fraud or deceit are vague and there is no consensus as to what constitutes an abuse of the power. ${ }^{267}$ The result is that relief on these grounds can be expected only against its grosser and more flagrant manifestations. Secondly, the formal requirements of some of the actions 268 create burdensome difficulties for a plaintiff seeking recovery and, in the case of a small shareholder or creditor, the costs and difficulties of prosecuting render it prohibitive.

Finally, where a corporation silently purchases shares on an exchange, buyers and sellers are almost totally unprotected because there exists no privity between the corporation and themselves and the vulnerability of these individuals represents a major inadequacy of the common law in this area. ${ }^{269}$

It is clear, therefore, that the protection afforded by the common law is vague and inadequate to protect against potential abuses that can arise under a general power to purchase. It is submitted that absolute prohibition is not the answer but rather what is required is a legislative standard of guidance and control. The protection of creditors and shareholders should not be left to the courts since ". . . it is not the function of courts to create such safeguards any more than it is the function of the courts to create corporations. The function of the courts in this matter is solely to ascertain the intent of the legislature, as evidenced by the statutes which it has passed."270 Legislation on the subject should indicate the circumstances and conditions under which a share purchase may be considered lawful and proper, and free from attack by shareholders or creditors.271 More specifically, a leading authority has stated:272

264 Note, supra, n. 157 at 310.

265 Levy, supra, n. 5 at 10; Hormstein, supra, n. 17 at 619620 and 626.

260 Levy, supra, n. 5 at 10.

287 Nemmers, supra, n. 113 at 169 states: "Most states find fraud when the corporation is insolvent. . . But the definition of fraud beyond the insolvency situation varies widely."

26s For example, in an action for fraud or deceit, the plaintiff buyer or seller of shares must show by clear and convinçing evidence (1) a false representation; (2) in reference to a material fact; (3) with knowledge of the falsity; (4) and intent to deceive; (5) reliance on the representation; and (6) damage. Note, supra, n. 157 at 310.

269 Id. at 311.

270 Warren, supra, n. 125 at 547.

271 Counihan, supra, n. 138 at 144.

272 Ballantine, supra, n. 7 at 610 . 
What is needed is the imposition of carefully drawn statutory regulations as to the conditions under which the purchase of shares may be made, the source or basis of permissible withdrawals for payment, the status of the shares after they are reacquired, the affect of later resale, reissue or retirement of them, the accounting practices to be followed on their repurchase or reissue, and the liability of directors and shareholders for improper purchases.

This same authority said earlier:273

A serious dilemma in drafting a corporation law is to make it liberal enough to facilitate business transactions without undue formalities of checks and balances, of votes and consents of shareholders, and applications to courts, and at the same time not 80 lax that the management or the majority may manipulate the machinery to the prejudice of creditors or investors or the oppression of minority shareholders.

Therefore, it is axiomatic that the law which regulates the purchase by a corporation of its own shares should represent a balance of the interests of creditors, shareholders and the general investing public in protecting against management excesses and the practical needs of business in avoiding unduly oppressive and restrictive regulation. ${ }^{274}$

\section{Shareholder Authorization of the Existence of the Power} Iacobucci provides:275

We recommend that the consent of shareholders be required before a company is able to purchase its shares. Thus the statute should state that 'when authorized by its memorandum of association and subject to any restrictions contained therein' the company may purchase any of its shares. We regard the power as a fundamental one which the shareholders should be free to choose or reject. Requiring the power to be in the memorandum emphasizes the role of shareholders more than if the statute endowed every company with the power, thereby avoiding the meaningful resort to shareholder opinion.

Although such a provision would provide a ground rule in the corporation's memorandum or articles of association that both future shareholders and creditors would know about, it must be remembered that ". . . since it is customary for corporations to take advantage of any permissive feature of the corporation statutes, it is to be anticipated that all corporations incorporated under these modern statutes will allow such purchases."276 Further, the argument that the shareholders of a small private corporation may well desire not to allow such a power does seem to lose its force when considered against the fact that the power to purchase can be of extreme benefit to the close corporation.

Another possibility, however, would be to allow corporations to place any further restriction (in addition to those contained in the statute) on the exercise of their power to purchase their own shares by express provisions in the articles. Such a provision would give greater flexibility to the shareholders of a corporation in deciding the extent to which they desire the corporation to be entrusted with a power of purchase.

\section{Funds Available for Purchase}

There are two broad categories of funds available to a corporation to purchase its own shares: stated (or issued) capital and surplus.

273 Ballantine, supra, n. 187 at 465.

274 Note, supra, n. 157 at 307.

275 Iacobucci, supra, n. 51 at 121. The New Brunswick Report on Company Law, supra, n. 61 at 89 provides: "We agree with the Dickerson Committee that a corporation should be allowed to purchase its own shares unless ther are provisions to the contrary in the articles."

276 Kessler, supra, n. 120 at 661-662. 


\section{(a) Stated capital}

In formulating legislation governing a corporation's purchase of its own shares under a general power to purchase it has been suggested that ". . . the prime object to be kept in mind is the protection of creditors from shareholders and the protection of shareholders from one another by requiring the strict maintenance of what modern law calls 'stated capital'."277 The obvious reason has been explained as follows:278

Stated capital is the basis of the share and financial structure of a corporation. It arises from the consideration received in payment for shares issued and from surplus funds capitalized by voluntary action by the board of directors or by the issuance of shares as a dividend, and it stands as the only margin of security for the protection of both creditors and shareholders. It is the only basis of credit of a corporation. Withdrawals therefrom by one class of shareholders to the prejudice of another class or to the detriment of creditors should, in no instance, be countenanced. This limitation on the corporate power to purchase its own shares would require the courts to rigidly guard and protect the corporate credit base. It would be their duty to detect and defeat any scheme or device calculated in any way to place any portion of stated capital beyond the reach of creditors.

The attempted justification for allowing purchases out of stated capital (in other than "special circumstance" situations discussed earlier) is that adequate protection is afforded by a solvency restriction, which will be discussed below, plus the desirability of having flexibility for commercial development. Such arguments are difficult to accept, however, in light of the potential abuses which could arise even with a stringent duty placed upon the officers of the corporation by United States law, and despite the tight control of such regulatory bodies as the American Securities Exchange Commission. This argument is even more difficult to accept in Canada where such protective controls are not as well-developed.279

\section{(b) Surplus}

It has been said that the solution to the problem of control of purchases by a corporation of its own shares lies to a large extent in the statutory definitions of surplus as a source of funds available for such transactions. ${ }^{280}$ At common law, two definitions of surplus grew out of the majority American rule that the purchase be in good faith and do no injury to shareholders or creditors. The first was that a corporation has a surplus for the purpose of purchasing its own stock when its assets exceed its liabilities, excluding capital stock. 'The other and more orthodox view was that there was a surplus for this purpose where there was an excess of assets which exceeded liabilities including capital stock. ${ }^{281}$ The vagueness of the true meaning of the term "surplus" has led many writers to suggest that the statute must itself provide a definition, so as to remove any uncertainty that can arise as a result of

277 Pollis, supra, n. 131 at 420.

27\% Id. at 421-422. Other writers agree. For example, Kessler, supra, n. 120 at 666 provides: "Authors usually speak of stated capital requirements as a protection for creditors. They are also a protection for the shareholders. Their effect is obviously to keep the asset fund at a higher level than that which would otherwise be the case. As such, they prevent the dilution of the real value of the shares."Leblovic, supra, $n$. 4 at 66 states: "It appears to leave little or no protection or cushion for creditors and shareholders and would seem to give a great deal of scope to manipulation or persons deeking to strip the corporate assets." The effect of such a provision is merely to provide an alternate method for reduction of capital where the shares are subsequently cancelled: Leblovic, supra, n. 4 at 66.

278 Leblovic, supra, n. 4 at 66-67. It is of course arguable that the standard for share purchases should not be restricted because of these limitations, but rather that corresponding reforms in the other areas of corporate law should be instituted.

zso Nemmers, supra, n. 113 at 183.

281 Id. at $\mathbf{1 7 0 - 1 7 1}$ 
such difference of opinion. The true nature of the surplus being used in the acquisition becomes very important when one considers the strict liability often imposed by statutes upon directors and upon shareholders in cases of impropriety. ${ }^{282}$

There is an even more important consideration in defining the term "surplus" for the purpose of controlling corporate share purchases and this involves the source of such surplus. The necessity of proper classification of surplus as to its source is explained by the CICA:283

Dictionary definitions of the word 'surplus' relate to a remainder or excess, often in the sense of an arithmetical difference rather than in the sense of a surfeit or overabundance. In accounting 'surplus' has long been used to designate the excess of net assets over the total paid-in par value or stated value of the shares of a corporation. This usage is firmly established in company law and finance, and is not likely to be discontinued.

The convenient usage of the word surplus in the sense indicated above is recognized. Experience shows, however, that a single-word designation of surplus on a financial statement is not sufficiently informative. Lack of uniformity in practice has led to the use of a variety of terms and this has created inconsistencies and ambiguity in many financial statements. For clarity, in every case in which the term surplus is used, it should be qualified with wording related to the method of classification of the various elements of surplus, and to the statutory requirements, if any, as to designations or descriptions. Because of uncertainties as to its meaning, the use of the term 'Capital surplus, in financial statements should be avoided unless required by statute.

In recent years, more descriptive phrases have replaced terms which include the word surplus; for example, 'retained earnings' is used as an alternative to 'earned surplus'. The designation 'retained earnings' is preferable because it is considered to be more adequately descriptive.

An adequate view of a company's affairs requires information as to the source of any surplus shown in the balance sheet. $A$ basic distinction exists between amounts received by way of contributions and amounts earned in the conduct of the business (these being the only sources of realized surplus), and this difference should be recognized by classification in the balance sheet.

'Contributed surplus' has frequently been taken to include only amounts paid in by shareholders, but it may include capital donations from other sources as well, for example, capital contributions in the form of building sites or certain governmental subsidies ... Contributed surplus in the form of surplus paid in by shareholders includes premiums on shares issued, any portion of the proceeds of issue of shares without par value not allocated to share capital, gain on forfeited shares, proceeds arising from donated shares, credits resulting from redemption or conversion of shares at less than the amount set up as share capital, and any other contribution by shareholders in excess of amounts allocated to share capital.

'Retained earnings' represent the accumulated balance of income less losses arising from the operation of the business, after taking into account dividends, refundable taxes and other amounts that may properly be charged or credited thereto. When the accumulation is a negative figure, the single word 'deficit' is a suitable designation.

It is argued that to permit a corporation to purchase its own shares out of capital or contributed surplus is not unduly harsh to creditors. They have no more right to rely on a contributed surplus than on an earned surplus (or retained earnings) for their protection, since in either case it resulted from the business activities of the corporation ${ }^{284}$ and would tend to increase or decrease with the company's relative prosperity.

282 Farano, The Business Corporations Handbook, (1971) at 46. The Canada Business Corporations Bill went even further and avoided any reference to an acquisition "out of surplus" or "out of capital". Instead, the terminology of the Income Tax Act was employed to determine whether a surplus exists: where assets would be more than aggregate liabilities and capital. Supra, n. 151 at 9.

283 Accounting Recommendations, (August 1974) at section 3250. These classifications are adopted for the purposes of this paper.

$2 \times 4$ Assuming of course that "business activities" include the issuing of shares at a premium, etc. 
Even assuming this is true, however, the shareholders are subjected to vicious abuse where purchases are allowed out of contributed surplus. For example, contributed surplus includes funds received from the issuance of preferred shares, since they are not part of the stated capital, and, by allowing the depletion of this source of funds for the purchase of the corporation's common shares, the preferred shareholders are effectively compelled to bear part of the corporate risk with the common voting stock. This is contrary to the principle espoused by many writers that the very existence of a preference right speaks for a lesser risk than that of the common share. ${ }^{285}$ As Professor Dodd states:286

Purchases of common shares out of surplus paid in by preferred shareholders is thoroughly vicious and might reasonably be held to be contrary to the fair implication of the preferred shareholder's contract even where the statute permits purchase out of surplus of any and all kinds.... If preferred shares are to be an appropriate investment medium, they must be safeguarded by a substantial cushion of assets made up of contributions by common shareholders which cannot be handed back to members of the latter group by a friendly management.

Although perhaps less objectionable in certain circumstances, the purchase of common shares out of contributed surplus where the corporation has no outstanding preferred shares should also be forbidden. ${ }^{287}$ As one commentator explained:288

The prohibition against the purchase of shares out of unearned surplus is a further safeguard for creditors and shareholders. In the small corporation, haveing but one class of shares, all of which contributed equally to paid-in surplus, there is little objection to the purchase of shares from that source (provided, of course, that the purchase price and circumstances of purchase are fair to the other shareholders). On the other hand, the usual financial structure of the modern corporation, working with all possible permutations and combinations of the various legal incidents of shares, presents a staggering number of different classes of shares. The contributions of one class should not be used to purchase shares of another class.

The majority of the American legislation on this point appears to have recognized these potential abuses and have restricted corporate share purchases to earned surplus or retained earnings. ${ }^{289} \mathrm{It}$ is generally agreed that the basis of this restriction is that both creditors and shareholders have a right to expect that all of the corporation's capital contributions be preserved, but have no call upon the profits derived from true business activities as this is distributable as cash or stock dividends. In effect, the corporation is merely being allowed to distribute its profits to its shareholders by another method.280

\section{Solvency or Liquidity Restrictions}

In addition to the restriction of funds available for the purchase by a corporation of its own shares, another possible safeguard is to impose a solvency or liquidity restriction on such purchases to ensure that the

28s Leblovic, supra, n. 4 at 65 . He recognizes, however, that in many cases, as noted above, the preference share may well be used to get around the stricter limitation placed on the corporation's acquisition of its own common shares, with the preference to be protected being nothing more than an illusory technicality.

236 Supra, n. 67 at 707.

237 Id. “. . . it is doubtful whether it is wise to empower the management to decide that a corporation which has no earnings should return part of the shareholders' contributions to them either by way of dividends or of share purchases."

2so Pollis, supra, n. 131 at 422 . See also the quote from Stevens, supra, at n. 212

289 See Model Business Corporation Act Annotated, supra, n. 120 at 258-260.

200 Leblovic, supra, n. 4 at 64-65. Kessler, supra, n. 120 at 662 provides: "Creditors can certainly have no legitimate objection to share repurchases from earned surplus, since their extension of credit is not justifiably made in reliance upon this fund as security for payment." 
corporation has liquid assets out of which to make such purchases. ${ }^{291}$ In effect, such restriction requires that the corporation must not be insolvent at the time of purchase or rendered insolvent thereby. This restriction also grew out of the majority American common law rule requiring that a corporate share purchase be in good faith and that it should not injure the creditors or shareholders. ${ }^{292}$ Solvency, however, can be viewed in two senses: (1) the "equity" sense where the corporation is unable to pay its debts as they fall due; and (2) the "bankruptcy" sense where the realizable value of the corporation's assets is less than the aggregate of its liabilities and stated capital. ${ }^{293}$

Commentators are generally agreed that both aspects of solvency should be used to control corporate share purchases.294 This dual requirement would seem essential to creditors since a dying corporation may still be able to meet its obligations as they fall due (i.e., be technically solvent in the "equity" sense), although its realizable assets are less than its total liabilities and capital stock (i.e., insolvency in the "bankruptcy" sense). ${ }^{295}$ In discussing section 257(1) of the British Columbia legislation which imposes an insolvency limitation which is defined in section $1(1)$ in the "equity" sense only, Professor Getz states: ${ }^{296}$

It is obviously right that the current creditors of a company should be able to insist that payment of their debts should have priority over the distribution of corporate assets to shareholders. It is also sound to insist, as the 'liquidity' test in effect does, that a company should have cash out of which such purchases can be made. Is it right, however, to permit a company which meets these requirements, but which has suffered a serious diminution of capital through past trading losses, to use a current surplus to reacquire its own shares? It might be argued that since a payment of dividends in such a situation-a so-called 'nimble' dividend-is permissible, there is no reason to treat any other form of distribution of corporate assets any differently. At least when viewed from the perspective of creditors, however, both transactions are equally objectionable as impairing their safety margin, and the dividend rule is not one which, viewed from this perspective, has commanded universal admiration. From a shareholder's point of view, there is an additional objection to a repurchase made in these circumstances, which is not applicable to a dividend payment. A dividend payment, as has been noted, would treat all shareholders of a class alike; a repurchase need not. Not only might it significantly affect the relative positions of the shareholders, but it would also result in funds contributed by one group of shareholders-those whose shares are not reacquired-being used to pay out the other. Simply put, the objection to the insolvency limitation of section $257(1)$ is that it permits a repurchase to be made so as to leave capital impaired, or further impaired, by a transaction not in the ordinary course of trading - a procedure roundly condemned in the United States for many years, and rejected both in Ontario and in the federal bill for Canada.

zyi Getz, supra, n. 45 at 12. Counihan, supra, n. 138 at 144 goes so far as to suggest that at least a two-to-one ratio of current assets to liabilities should remain after a corporation has completed purchase of its own shares.

292 Nemmers, supra, n. 113 at 171.

293 The fact that the test for solvency in the "bankruptcy" sense allows for the revaluation of assets for its determination is discussed in Comments of Osler, Hoskin \& Harcourt on the 'Proposals for a New Business Corporation Law for Canada' (1972) at 13; and CICA, supra, n. 236 at 55-56. They suggest further that not only should the test be employed but that it should be expressed positively rather than negatively so that the directors must then seek evidence of solvency rather than merely being unaware of evidence of insolvency.

294 Kessler, supra, n. 120 at 665; Iacobucci, supra, n. 51 at 121-122; New Brunswick Report on Company Law, supra, n. 61 at $89-90$. Getz, supra, n. 45 at 12-13.

29s Kessler, supra, n. 120 at 665.

296 Supra, n. 45 at 12 . He notes, however, with respect to the definition (at 13): "As already noticed, however, 'insolvency' is defined to 'include', rather than to 'mean', inability to pay debts as they fall due. Does it also include some other test, such as, for example, the liabilities exceeding the realizable value of the assets of the company-which is the alternative test used in both the Ontario Act, and the federal bill, and which is, of course, one of the tests of insolvency under the Bankruptcy Act. There is authority for the view that, in the absence of statutory definition, the term 'insolvent' means an inability to pay debts as they fall due, and this view seems implicit in the drafting of the Ontario Act and federal bill. In British Columbia, the question seems an open one, the answer to which will depend upon which of the competing maxims of statutory interpretation the courts will adopt. 
Finally, an important aspect of the solvency restriction, not only as a safeguard for creditors but also for the directors of a purchasing corporation, is to provide an access for the directors, if they feel it is necessary, to apply to the court for a declaration as to whether in all the circumstances the corporation is insolvent or would be rendered insolvent by the proposed purchase. ${ }^{297}$ Although in a clear case such a provision would not be resorted to, it is advantageous to provide the directors with such access to the court where the solvency of the corporation is in doubt. Such a provision also increases the justification for imposing strict and onerous liabilities on the directors for authorizing improper purchases.

\section{Agreements to Purchase Shares: Purchases "In Futuro"}

The safeguarding of abuse along with the facilitation of the benefits that can arise out of an agreement entered into between the corporation and a shareholder to purchase shares at a certain or ascertainable future date merits special consideration. In content, these agreements are either obligatory (binding on both sides) or options (with the option exercisable at the election of the corporation, on the shareholder, or both).298

Where such an agreement has been entered into, the possibility exists that, at the time when the company is called upon to perform its obligations under the agreement, it may be unable to do so in view of the surplus and insolvency restrictions in the statute governing such corporate share purchases. The question than arises whether the contract to purchase is enforceable. The answer provided by the common law of the United States is unclear. ${ }^{299}$ For example, there were a number of cases which held that one who had purchased shares from a corporation in reliance on its agreement to repurchase them at a later date could neither enforce the purchase agreement nor obtain restitution of the price paid if the corporation was insolvent at the time the enforcement or restitution was sought. 300 On the other hand, since courts have treated such agreements as valid or permitted restitution to a purchaser who had bought in reliance upon them, even though a purchase of shares by the corporation, not made pursuant to an agreement, would have been invalid in the circumstances. ${ }^{301}$ Because of the uncertainty surrounding the common law, it has been suggested that the status and rights of the parties to such agreements be clarified explicitly in the statute. 302

The important consideration surrounding such agreements concerns the determination of the appropriate time to apply the surplus and solvency tests. If they are to be applied at the time the contract or agreement is entered into, the corporation will usually be solvent and have a surplus and the transaction would therefore be permissible. If

\footnotetext{
297 Iacobucci, supra, n. 51 at 122. The British Columbia legislation contains a provision: section 257(2).

298 Hornstein, supra, n. 17 at 621 . This type of agreement must be distinguished from the situation where the corporation purchases its own shares and defers the actual payment of the purchase price by giving a note or other security for the amount. This situation will be discussed later in relation to the purchase price paid for shares purchased by a corporation.

200 Baker and Cary, Cases and Materials on Corporation (3d ed.), (1959) at 1423-1426.

300 McIntyre v. E. Bement's Sons (1906) 146 Mich. 74; Hegarty v. American Com. Power Corp. (1934) 174 A. 273.

301 Schulte v. Boulevard Gardens Land Co. (1913) 120 P. 582; Williams v. Maryland Glass Corp. (1919) 106 A. 755.

302 Iacobucci, supra, n. 51 at 123-124; Getz, supra, n. 45 at 29-30. Hornstein, supra, n. 17 at 622 suggests as well that such agreements should be required to be in writing 80 as to prevent possible abuse. Some courts have held an oral promise to purchase shares beyond one year into the future not barred by the Statute of Frauds: Downs v. Jersey Central Power \& Light Co. (1934) 170 A. 835.
} 
applied when either the shareholder or the corporation elects to enforce the agreement, the opposite may well be true. Clever shareholders may thus be able to secure for themselves all the benefits of shareholders if the business prospers, while at the same time possessing all the safeguards of creditors if the business fails. ${ }^{303}$ The recommended treatment of an agreement for the purchase by a corporation of its own shares at some time in the future is that it not be considered invalid or unenforceable merely because there is a possibility that the corporation may not be able to comply with the solvency and surplus restrictions imposed by statute. Rather, it should be considered valid and enforceable to the extent that the corporation is able to meet these tests at the time fixed for payment. ${ }^{304}$

Another consideration concerns the question of whether certain types of purchase agreements should be accorded special treatment, namely, that the corporation, at the time of enforcements be entitled to purchase the shares out of any type of surplus or even out of stated capital subject only to a solvency restriction. Such agreements are not uncommon in three different situations: (1) as part of an original share subscription contract, (2) where the shares are issued as part of an employee incentive plan, and (3) in a close corporation to insure that on the retirement or death of one of the participants the corporation will remain "close", in effect, that the remaining "partners" may control the entry of the replacement into the enterprise. Each of these situations can be considered separately.

\section{(a) Agreement to Purchase as Part of an Original Share Subscription}

Ballantine is especially severe on this type of contract, despite its general judicial acceptance in the United States: ${ }^{305}$

There has been a good deal of recognition of the validity of agreements, made as part of a subscription to shares, to repurchase them on the demand of the subscriber if the subscriber becomes dissatisfied with his investment. Such repurchase agreements are generally part of some stock selling scheme by high pressure salesmen. Some courts have even made a judicial exception in favor of this practice under statutes restricting withdrawal of 'capital stock' or forbidding purchases except out of surplus. Specious reasons have been assigned to explain the upholding of such escape provisions, as that the transaction is only a conditional sale or a 'sale and return contract,' and that the corporation cannot retain the subscription price and at the same time repudiate the illegal agreement to repurchase. This is even carried so far as to validate an agreement to pay a premium on repurchase and to pay interest as part of the purchase price, obviously illegal. Such agreements, used to entice reluctant and inexperienced subscribers, should be condemned as dangerous to creditors and unfair and discriminatory as against other shareholders even if creditors are not immediately threatened.

It is a peculiar anomaly that a strict rule restricting releases and escape provisions in original stock subscriptions exists alongside a lax doctrine upholding repurchase agreements under which a subscriber can withdraw his investment from the corporation. An agreement to escape liability upon an unpaid subscription is no more contrary to the 'trust fund doctrine' than an agreement by which a shareholder resells and receives back from the company the amount paid on his subscription and equally opens the way to fraud on creditors and other shareholders. The release or rescission of a subscription differs little in financial effect from the repurchase of partly paid shares.

Levy as well rejects in principle such agreements: ${ }^{306}$

303 Kessler, supra, n. 120 at 677.

sus Farano, supra, n. 282 at 46 . This was the approach adopted in Ontario.

sus Supra, n. 7 at 613-614.

:w6 Levy, supra, n. 5 at 34-35. Dodd, supra, n. 67 at 712 provides: "'your money back if you are not satisfied with 
From a social standpoint, it is of questionable value to permit corporations to sell their stock with the right in the vendee to resell to the company if dissatisfied. A share of stock is different from an ordinary chattel, and a sale of stock with an option to return it presents a different situation from a similar right attached to the sale of common merchandise. Certainly creditors, if unaware of such reservations to the subscription, might protest against the exercise of this option when the venture has become a bad one, for the subscriber will then want his money back and will seize upon the right to return the shares. The creditor will be looking to the capital of the failing enterprise for the satisfaction of his claim. To permit the shareholder to exercise his power in such a case is to prefer him to a creditor, or at least to convert him into a creditor. To call this practice a rescission of a sale or the failure of a conditional sale may be a legalistic differentiation, but it does not alter the fact that the conditional shareholder is being given a preference.

Furthermore, consider the position of other shareholders who have subscribed with no such reservation. If they are unaware at the time they subscribe of the conditions to the subscriptions of others, the deceit is apparent. For the difference between entering a venture in which all the capital has been unconditionally contributed, and one in which there are some capricious subscripions is great.

Professor Dodd, however, suggests that the development of the law protecting to some extent the shareholder who is a party to such an agreement was not to be unexpected: ${ }^{307}$

If, however, the state does not effectively prevent corporations from baiting the hook for the investor in this manner, it is easy to lend a sympathetic ear to the investor's contention that the promise to repurchase, which induced him to part with his money, should be enforced, even in the teeth of a statute forbidding purchases of shares out of funds other than corporate surplus. Repurchase agreements are part of the stock in trade of those security salesmen who distribute shares in speculative enterprises to financially illiterate and, generally speaking, relatively impecunious buyers. Such persons are likely to be financially less able to suffer the hardship of losing their money than is the average corporate creditor. It is, therefore, not surprising that in most of the earlier cases the courts permitted the shareholder to get his money back without injury as to the existence of any corporate surplus, nor is it surprising that a number of courts reached this result in spite of statutes which had previously been construed as forbidding purchases of shares, or purchases which involved a withdrawal of capital. Various legal formulae have been made use of in an effort to rationalize this result. All of them, however, slur over the patent fact that, if such agreements are enforceable despite the non-existence of surplus, shareholder-owners are thus, by virtue of an invisible and unsuspected string attached to their shares, allowed to impair the margin of safety provided for creditors.

Even those courts which adopt a sympathetic attitude towards investors who have purchased in reliance on such agreements generally refuse to enforce them if the corporation is insolvent at the time when the shareholder seeks to obtain repayment. Nearly all of the recent cases arising under statutes which explicitly limit purchases to surplus or forbid purchases out of capital have gone further and held that these repurchase agreements constitute no exception to the statutory rule. Whether this modern trend is due to increasing judicial awareness of the evil effects, on shareholders and creditors alike, of permitting capital to be dissipated in this manner, or is due to the greater explicitness of most of the more recent statutory provisions imposing restrictions on purchases of shares, is not entirely clear. At all events, in jurisdictions where there are no statutory provisions on the subject, the judicial tendency is still in the direction of permitting one who has purchased shares on the faith of a repurchase agreement to recover his money, provided the corporation remains solvent. This is so even where the facts indicate or strongly suggest that the corporation had no surplus.

Generally, surplus and solvency limitations are imposed by statute on a corporation's purchase of its own shares whether pursuant to an existing agreement or not. Even if agreements to purchase as part of an original subscription are to be allowed, ${ }^{308}$ and when recourse to such

our product' is a product wholly unsuited to a transaction in which 'our product' is a certificate representing ownership rights in a corporation and purporting to involve a permanent contribution to its capital."

s07 Id. at 712-714.

suw The initial validity of such an agreement might properly be regulated or controlled by securities legislation, at least with respect to the marketing of public issues. 
agreements must be had, for example, if no other means of raising capital for the corporation is available, there appears to be no reason to accord them any special treatment such as enlarging the scope of available sources of funds with which to complete the purchase. Therefore, the enforceability of such agreements should be subject to both the solvency and surplus limitations applied at the time fixed for payment.

\section{(b) Agreement to Purchase as Part of an Employee Incentive Plan}

As mentioned earlier, employee incentive programs are desirable since they do stimulate better efforts on behalf of the corporation, but this advantage ceases when the employment terminates, and prudent management therefore requires the departing employee to surrender his shares and rights to purchase shares. In addition, in view of the special circumstances under which such an investment is made, the application of the restrictions limiting enforcement of the agreement to circumstances where both the solvency and surplus restrictions are met can have unfortunate consequences for both parties, particularly for the employee-investor. ${ }^{309}$ As a result, many statutes treat such agreements as a "special circumstance" and empower the corporation to purchase shares even out of stated capital pursuant to an agreement with an employee other than an officer or director subject only to the solvency restriction. ${ }^{310}$ In addition, some statutes have inserted the requirement that the employee be a bona fide full-time employee to further prevent potential abuse.

\section{(c) Agreement to Purchase in the Close Corporation}

An agreement between a close corporation and a major shareholder providing for the corporation to purchase its shares on the death or retirement of the shareholder have not been accorded any special treatment in the statutes. This is justifiable since it could result in undue prejudice to creditors for a corporation to purchase the shares out of stated capital since, in a close corporation, those shares may represent a substantial portion of the corporation's capital. ${ }^{311}$ Therefore, the enforceability of such an agreement will depend on whether both the solvency and surplus restrictions are satisfied at the time fixed for payment. The corporation may assure itself of sufficient surplus to exercise its right of purchase on the death of a participant by appropriate insurance policies. In the event of either death or retirement, the agreement should also provide for an option in the remaining shareholder to personally purchase all or any of the shares the corporation is unable to due to insufficient surplus or insolvency.312

\section{Purpose of the Purchase}

Generally speaking, the corporation is protected from purchases of its own shares for improvident purposes by the standards of fiduciary duty

309 See the discussion of Professor Dodd, supra, n. 262.

:10 Model Business Corporations Act Annotated, supra, n. 120 at 261. The other method of providing for employee incentive programs is through the use of participating redeemable preferred or "special" shares as they are called in Ontario: see Iacobucei, supra, n. 51 at 117. Hornstein, supra, n. 17 at 621 provides: "Few questions can arise when repurchase is provided for in the articles of incorporation pursuant to statutory authority. Such authority is, however, usually limited to preferred shares (or 'special' stock)."

311 In an employee incentive plan, the shares purchased are only a small portion of the corporation's stated capital and, as further assurance of this, officers and directors who are also employees are usually excluded from benefitting from this exception.

312 Kessler, supra, n. 120 at 669. Again the use of "special" or preferred shares can present a partial solution to the problem: Iacobucci, supra, n. 51 at 117. Pollis, supra, n. 131 at 428 adds: "To safeguard against fraud, repurchase contracts should be in writing." 
which bind the directors in all transactions involving the corporation. The fiduciary duty in this regard has been expressed in various ways, such as ". . . the power of a company to purchase its outstanding common shares shall be exercised only by the directors acting in good faith and in the best interests of the company" 13 or "... the purchase ... must be made for a proper corporate purpose." 314 As a result, directors may be liable for a breach of their fiduciary duties where they cause the corporation to purchase its own stock for the purpose of manipulating or maintaining voting control, self-dealing at an excessive price, rash speculation in the market or removing a troublesome shareholder. ${ }^{315}$

It may, however, be difficult for a court to determine the real motive of the directors in causing the corporation to purchase its own shares. ${ }^{316}$ This is especially so where the purchase has removed an insurgent and has been explained as follows: ${ }^{317}$

In the absence of a valid reason to sustain this power, directors should not be permitted to cause the corporation to purchase its shares if their motive is to preclude the challenge of an insurgent. There may be instances, however, in which the directors can justify the corporation's purchase on some independent ground, even though the result of the transaction is also to eliminate a potential challenger. Thus the motive of the directors must be proved to sustain a cause of action. In determining motive, the assignment of the burden of proof on this issue is crucial. Since the facts which indicate the motivation of such a purchase are probably accessible only to the directors, to compel the plaintiff to prove the intent of the purchase would impose an almost insurmountable burden, and would, in effect, insulate the directors' action from challenge. Thus it might be more realistic to shift the burden to the directors, after the plaintiff-shareholder makes a reasonable showing that the purchase resulted in the elimination of a shareholder whom the directors viewed as a potential insurgent. Although the burden of proof rests somewhat easier upon defendants than it would on plaintiffs, it may still be dispositive in many cases. This disadvantage seems consonant, however, with the general doctrine that directors must prove the fairness of corporate transactions which work to their personal advantage.

\section{Manner of Purchase: Procedural Requirements}

Controlling the manner by which a corporation is entitled to purchase its own shares can result in the prevention of a great deal of the potential abuse that surrounds the granting of a general power to purchase. The alternative procedural requirements that can be imposed will now be considered. It is necessary, however, to again point out that in imposing procedural requirements or restrictions on corporation share purchases, the competing interests of corporate flexibility and efficacy and protection of shareholders, creditors and the general investing public must be considered and hopefully, optimally balanced.

\section{(a) Preliminary Authorization}

Preliminary authorization of a corporate share purchase could take the form of a directors' resolution, shareholder authorization or

II: The Lawrence Report, supra, n. 180 at 38.

:11 New Brunswick Repprt on Company Law, supra, n. 61 at 89.

.115 Where the directors are found to have breached their fiduciary duties by causing the corporation to purchase its own shares for an improper purpose, they will be personally liable. The extent of such liability will be dealt with later in relation to sanctions for improper purchases.

316 Nussbaum, supra, n. 66 at $982-983$.

3: Note, supra, n. 177 at 317. See also Bergmann, Directors' Right to Purchase Company Shares with Company Funds, (1965-66) Corporate Practice Commentator 362. This question of burden of proof was not discussed elsewhere in any of the materials available to the writer. Statutory recommendations or examples could not be found placing a direct burden on the directors. It is a principle of the law of evidence that the burden of proof may be placed on the party having a peculiar means of knowledge of relevant facts: Wigmore on Evidence (3d ed.) (1940) at s. 2486 . 
ratification, court approval or, conceivably, a combination of either or all of the above.

The requirement that a purchase be authorized by a resolution of the board of directors is favourable since the matter is one of sufficient importance to ensure that it not be left to officers of the corporation or their subordinates. ${ }^{318}$ Such a requirement is further justified in light of the stringent liabilities placed upon directors for improper corporate share purchases by most corporation statutes.

Shareholder approval of a purchase by a corporation of its own shares can also be imposed. Such required approval could either be in the form of a simple majority or ordinary resolution or a special resolution 80 as to provide some protection for the minority shareholders. Professor Kessler suggests that approval should be required not only of the shareholders of the class of shares being purchased but also by shareholders of both superior (in either dividend or liquidation preference) and junior classes: ${ }^{319}$

Otherwise, holders of controlling blocks of common shares could divert all the corporate surplus to their own shares. . . . Furthermore, purchase of shares senior to their own offers a possibility of damage to all shares junior to those purchased. Many people, judges included, apparently forget that 'what's gone is gone'. Money spent for senior shares is that much less for junior shares in dividend or liquidation value, and this is true despite bookkeeping entries to the contrary. The protection of junior shareholders . . . requires their approval of all purchases from classes senior to them, since whatever goes to these senior shareholders means correspondingly less will go to them. . . .

Purchases of senior shares may be used to divert surplus otherwise available for dividends to junior shares to such preference issues. Purchases of junior stocks may dissipate surplus even below that necessary to assure payment of the fixed dividend preferences of senior issues. Consequently, the only safe provision is to require purchases of shares of any class to be approved by all classes whether normally voting or non-voting.

The obvious argument against requiring shareholder approval as a condition precedent to a corporate share purchase is that it seriously detracts from the reasons for the purchase power in terms of both time and efficacy. Not only could the holding of a vote be cumbersome, expensive and time-consuming but any purchase could effectively be vetoed by any class of shareholders. Such a restriction can thus perhaps be viewed as an undue limitation on corporate flexibility especially when considered against the other restrictions of director responsibility, source of funds limitations and solvency requirements.

Shareholder satisfaction of a completed purchase is less desirable mainly because of its minimal utility. Ratification after-the-fact has been criticized as a useless requirement since it is often seen as a "rubber stamp" procedure of an act already completed and not considered revocable.

In any event, authorization or ratification cannot validate an otherwise improper purchase since ". . . shareholders cannot possibly waive the protection the law grants primarily to creditors and to the public at large." 320

Finally, court approval could be required. This restriction, however,

310 Iacobucci, supra, n. 51 at 122. Farano, supra, n. 282 notes that the legislation should be specific in that each purchase must be expressly authorized rather than allowing a "blanket resolution" authorizing purchases from time to time in the future.

319 Kessler, supra, n. 120 at $671 ; 673$.

320 Nussbaum, supra, n. 66 at 1001. 
suffers to an even greater extent the criticism that it substantially detracts from the basic efficacy which flows from a general power to purchase. However, a discretionary right to apply to the court for a determination of a corporation's solvency, as has been noted earlier, can be a valuable provision.

\section{(b) Procedure of Purchase}

It has been suggested that legislation empowering a corporation to purchase its own shares should give the corporation the power to establish its own procedure for carrying out purchases but that a statutory procedure should apply where no procedure has been specified in the corporation's memorandum or articles of association. ${ }^{321}$ It has been further suggested that a corporation should be able to purchase its shares pursuant to a procedure provided in an unanimous shareholder agreement. 322 Such a provision would only be effective in small corporations and the required unanimity would ensure that all the parties had an opportunity to ascertain all the facts before any purchase took place. These recommendations obviously have a great deal of merit since they would provide the much-needed flexibility of procedure so necessary to the close corporation in exercising a general power to purchase its own shares.

With respect to statutory procedural requirements, where a listed or public company purchases its own shares through the medium of a stock exchange, most statutes do not impose any limitations upon it such as a pro rata offering to shareholders. Commenting on the application British Columbia legislation, Professor Getz explains: ${ }^{323}$

A repurchase to be effected by a listed reporting company through the facilities of the
stock exchange need not be by means of a pro rata offer to purchase. There is, of
course, precedent for according special treatment to transactions conducted on an
exchange. Section 78(b) of the Securities Act, for example, places outside the scope of
the 'take-over' provisions of that Act a so-called 'exempt offer', which is defined in
section 78(b)(ii) as 'an offer to purchase shares to be effected through the facilities of a
stock exchange or in the over-the-counter market.' The theory behind this exemption
was described in the Ontario Securities Commission Report on Business Combinations
and Private Placements (the 'Merger Report') as 'straightforward. No special effort is
made to force the offeree shareholder to sell. He bases his decision on the market price
of the securities. . . .324
This theory applies with equal force to a market purchase by the company. Insofar as
the critical consideration is the price at which the vendor shareholders sell, the two
cases are the same. Any shareholder could presumably sell his shares to someone at
that price, so that the principle of equal opportunity with respect to price is not
threatened in this respect by a market purchase by the company. The market
establishes the price.

Where a corporation is purchasing its own shares "privately", so to speak, in transactions whereby it deals directly with the selling shareholders, the remaining shareholders who choose not to or, more importantly, are not given the opportunity to sell can be prejudiced both with respect to dilution of surplus otherwise available for dividend and alteration of intra-corporate voting control. To prevent such potential abuse, some statutes have imposed the requirement that a corporation intending to purchase its own shares must make a pro rata offer to all

\footnotetext{
321 Iacobucci, supra, n. 51 at 122

322 CICA, supra, n. 236 at 5-5.

323 Supra, n. 45 at $18-19$.

324 (1970) para. 7.11.
} 
shareholders of the class of shares to be purchased at the same price. ${ }^{325}$ The rationale for such a requirement is that a corporate share purchase is substantially equivalent to a dividend and thus prima facie should be made available to all shareholders on a pro rata basis. ${ }^{326}$ Any "bonus" on the purchase price would result in the same equitable distribution of surplus as would a dividend (at least to those electing to sell), even if the price paid is over the market value (so long as the same price offer is made to each member of the class to purchase his shares in the proportion held). As long as his pro rata share of corporate surplus is distributed in this way, no shareholder has grounds for complaint. ${ }^{327}$

It is important to point out, however, that to impose a strict and inflexible requirement of a pro rata offer may well defeat the purpose of entrusting corporations with a general power to purchase their own shares in the first place. ${ }^{328}$ Furthermore, it does not provide a complete removal of potential abuse, as Professor Getz explains: ${ }^{329}$

The purpose of the pro rata offer requirement is thus to afford each member of a class the same opportunities as every other member of that class. But its effects should not be overestimated. While it affords substantial (but not complete) protection against financial dilution, it does not guarantee equality of treatment, or even the opportunity for equal treatment, with respect to dilution of voting strength, unless every member of the class behaves in an identical way. Unless every member of the class sells the same

J25 Kessler, supra, n. 120 at 668 explains: “'Pro rata offer' here means 'tender offer,' whereby a corporation would offer to repurchase, at a given price, a fixed proportion of each shareholder's shares in a company. E.g., if there are 3,000 outstanding shares in a corporation held by three shareholders, each holding the shares indicated in the following table, and each share having a market price of $\$ 10$, the corporation might offer to repurchase as follows:

\begin{tabular}{|c|c|c|c|c|c|}
\hline Shareholder & $\begin{array}{l}\text { (a) } \\
\text { Shares } \\
\text { Held }\end{array}$ & $\begin{array}{c}\text { (b) } \\
\text { Price } \\
\text { Offered by } \\
\text { Corp. Per } \\
\text { Share }\end{array}$ & $\begin{array}{l}\text { (c) } \\
\text { Shares } \\
\text { Which } \\
\text { Will Be } \\
\text { Accepted } \\
\text { By } \\
\text { the Corp. } \\
\text { Under the } \\
\text { Offer }\end{array}$ & $\begin{array}{c}\text { (d) } \\
\text { Voting Control } \\
\text { Held Prior to } \\
\text { Repurchase }\end{array}$ & $\begin{array}{l}\text { (e) } \\
\text { Voting Control } \\
\text { Held Subsequent } \\
\text { to Repurchase } \\
\text { (if each share } \\
\text { holder sells all } \\
\text { of the shares } \\
\text { indicated in } \\
\text { column (c)) }\end{array}$ \\
\hline \multirow[t]{2}{*}{$\mathbf{A}$} & 1000 & $\$ 11$ & $25 \nRightarrow=250$ & $1000=331 / 3 \%$ & $750=331 / 3 \%$ \\
\hline & & & & 3000 & 2250 \\
\hline \multirow[t]{2}{*}{ B } & 1500 & $\$ 11$ & $25 \%=375$ & $1500=50 \%$ & $1125=50 \%$ \\
\hline & & & & 3000 & 2250 \\
\hline \multirow[t]{2}{*}{ C } & 500 & $\$ 11$ & $25 \%=125$ & $500=162 / 3 \%$ & $375=162 / 3 \%$ \\
\hline & & & & 3000 & 2250 \\
\hline
\end{tabular}

326 Israels, supra, $\mathbf{n} .125$ at 352 . Note that such a requirement did not exist under the American majority common law rule allowing such purchases: Nemmers, supra, n. 113 at 176.

s2 Kessler, supra, n. 120 at 669 . Ellis and Young, supra, n. 121 at 62.63 provide "When substantial amounts of stock are to be reacquired, a tender offer will give all stockholders equitable treatment. Such a tender offer should be priced sufficiently above current market levels to balance the advantages of possibly higher future per share earnings and equity values to those who may wish to hold their shares." CICA, supra, n. 236 at 5-5 also advocated this requirement: "Public companies could only repurchase shares through a tender offer to all shareholders, the shares of shareholders who wish to sell being to take up pro rata when more shares are deposited than are bid for. Such a tender offer should be accompanied by a circular giving reasonable disclosure as to the reasons for the offer, and, in particular, the intentions of directors and major shareholders as to accepting the offer. The basis upon which the offered price has been established should also be disclosed."

32N The obvious example is the use of the power to facilitate retirement of a partner in a close corporation. A pro rate requirement in such a situation would be unduly cumbersome. However, the offer to purchase shares must be made pro rata and not the actual purchase itself. This eliminates the objection raised by Zilber, supra, n. 158 at $320-330$ that such a requirement is not a practical solution since refusal by one shareholder to sell may serve as a veto on the purchase and, if not, the purchase might force some shareholders to liquidate their holdings against their will.

129 Supre, n. 45 at 16. The New Brunswick Report on Company Law, supra, n. 61 agreed: "There are arguments to be made for requiring a pro rata offer to buy from all shareholders before a proposed purchase of shares is made. The federal proposals do not have such a requirement. We think that many of the possible advantages in allowing a repurchase of shares would be destroyed by such a requirement and that the proper purpose restriction properly applied would prevent any abuses." 
proportion of his shareholding-a near impossibility in the absence of full disclosure to each person of what the others are doing-some dilution is bound to take place. What the pro rata rule does do with respect to voting power, however, is to add somewhat to the basic equitable protections given to shareholders against the misuse of management powers under the so-called 'collateral purpose' doctrine. Moreover, the pro rata requirement provides no protection at all against financial dilution to members holding shares of a class other than the one to be acquired, and it is obvious that the interests of one class can be severely prejudiced by the acquisition of shares of another class. . . . 330

Another method suggested for removing potential abuse is to impose a percentage limitation on the number of shares that a corporation can hold of its own stock. ${ }^{331}$ Such a restriction effectively limits most of the corporate efficacy flowing from the power to purchase shares except in those special circumstances. Its object, of course, is to remove potential abuse but in so doing it again effectively defeats the purpose of allowing a corporation to purchase its own shares in the first place. Furthermore, the impact of such a restriction would vary greatly since the effect of a percentage limitation will depend on the size of the corporation involved. ${ }^{332}$

\section{Purchase Price}

The price at which shares are purchased by a corporation can, of course, give rise to abuse where the price is either too low or too high. Presumably, it would seem that in determining the purchase price the directors of the corporation are subject to the normal fiduciary obligations of loyalty, care and skill and thus would be required to offer to purchase shares at a price which, from the corporation's point of view, is best obtainable. 333 Some statutes have gone the further step of expressly providing that under a general purchase power "the purchase shall be made at the lowest price at which, in the opinion of the directors, such shares are obtainable."334

Advocates of the granting to corporations of a general power to purchase their own shares feel that the possibility of abuse is removed provided the corporation receives "full and clear value"335 or that no more than a "fair market value price" 336 be paid by the corporation. Clearly, where the shares are being purchased in the open market through an exchange the market establishes the price. However, the situation is different for a purchase outside the market. Professor Getz explains: 337

As a practical matter, a purchase outside the market ... will have to be made in the case of a listed company at some premium above the market, so that while the market will set the minimum price for the shares, it will not set the maximum or the optimum price. In the case of an unlisted share, of course, the problem of determining the appropriate price is a difficult one, to be solved without the restraining influence of the market.

:36 Kessler, supra, n. 120 at 669 adds two additional alternatives: (1) where there were so many shares outstanding that a corporation could not afford to take even a small percentage of each shareholder's stock, or many very small holdings exist, necessitating fractional purchases, an alternative might be the selection by lot of the shares to which purchase offer would be made; or (2) offers to purchase on a "first-come-firstserved" basis. Both, however, are widely scattered under the "first-come-first-served" basis, and require, as a result, too great statutory detail.

331 Id. at 681.682, where $5 \%$ is suggested as a maximum.

332 For example, $10 \%$ of Noranda Mines is a great deal hereas in a close corporation it would be insignificant.

323 Getz, supra, n. 45 at 19.

334 Section 39(5) of the Ontario Act.

335 Wormser, supra, n. 230 at 188.

wa Counihan, supra, n. 138 at 144.

3.17 Supra, n. 45 at 19. 
Two basic solutions have been put forward in answer to this problem. The first is the fixing of the price by disinterested appraisers ${ }^{338}$ but this suffers from the defect that is time consuming and, in most cases, costly and thus detracts from the efficacy of granting the general power to purchase in the first place. The second is the setting of a statutory maximum price to be paid (similar in concept to that for redeemable preferred shares) such as "... payment of no more than liquidation value." 339 Professor Kessler comments on this latter proposed solution: ${ }^{340}$

Such a formula as Stevens suggests, payment of no more than liquidation value, might be possible in the case of preferred shares, because the amount which they are to receive on liquidation is often fixed by their shareholder contract (often at par). . . However, as to common shares, this is either unworkable (e.g., at each purchase, good will would have to be evaluated and going concern and asset value recomputed), or so onerous (if interpreted to mean involuntary liquidation value, it would probably be so low as to effectively discourage any shareholder from selling, except in an artificially deflated market) as to effectively prevent all such repurchases. While Stevens' proposal would offer more complete protection, it could not be considered as a feasible answer to the problem.

The third solution, and the one almost universally adopted either expressly or impliedly, is to leave the purchase price to the decision of the directors who have access to all the relevant information necessary in order to make an informed decision and subjecting them to potential liability for breaching their strict fiduciary obligations. This leads to Professor Getz's comment that "[T] he best price for the company to buy is not necessarily the best price for the selling shareholder. What is of critical importance for shareholders, therefore, is access to information concerning the price of the shares, and the circumstances surrounding the company's interest in buying them."341 The requirement of full disclosure not only tends to prevent directors or senior shareholders from prejudicing the minority shareholders through corporate share purchases forhidden reasons, but it also allows each individual shareholder to whom an offer to purchase has been made to reach an informed decision whether to accept or reject.

A final aspect warranting consideration is the position of a selling shareholder vis-a-vis creditors when the corporation has given a note or other corporate obligation in return for the shares and subsequently becomes insolvent. Under the majority American common law rule allowing corporate purchases even out of capital, if a corporation was solvent when a note was given by it for the purchase price of shares surrendered, but it became insolvent at the maturity date of the note, the shareholder creditor by the better view was postponed to outside creditors. ${ }^{342}$

However it must be remembered that a purchase by a corporation of its own shares with payment deferred is much different than an executory agreement to purchase shares some time in the future. In the latter case, the shareholder remains a shareholder until the agreement is executed and as such is entitled to all the rights and benefits accorded

ast Counihan, supra, n. 138 at 144.

xiy Stevens, supra, n. 212 at 278.

340 Kessler, supra, n. 120 at 668.

341 Supra, n. 45 at 19.

34: Ballantine, supra, n. 7 at 608 and the cases cited therein, but contra, Wolff v. Heidritter Lumber Co. (1932) 163 Atl. 140; see Nemmers, supra, n. 113 at 172-175. This view is adopted by Professor Kessler, supra, n. 120 at 677: ". . . if the shares have already been surrendered and a corporate obligation given, the obligation will be subordinated to the rights of general creditors on . . . insolvency." 
the shareholder status. It is proper, therefore, that the purpose and solvency restrictions be applied when the agreement is executed thereby binding the company to make payment. In the former case, however, the selling shareholder is no longer a shareholder since he has surrendered his shares to the corporation and has therefore relinquished his rights (such as voting rights or rights to dividend payments) at that time. It would seem appropriate, therefore, that the selling shareholder who receives a note or other corporation obligation in return for his shares at a time when the corporation is able to meet both the surplus and solvency limitations should be entitled to stand as a general creditor should the corporation subsequently become insolvent. Furthermore, it might well be better for the corporation to give a note or other obligation rather than deplete its current cash or other liquid asset supply through a share purchase.

This view is supportable on a number of grounds. ${ }^{343}$ The first of course being that mentioned above. Secondly, if the corporation gives a standard promissory note or other negotiable instrument for the price of the shares it has purchased, the problem would arise with respect to the position of a third party purchaser of the note without notice that it was given in respect of a corporate share purchase and therefore is subordinated to the rights of general creditors of the company. Thirdly, the obstacle created by requiring the surplus and solvency tests to be met not only at the time the note is initially given upon the surrender of the shares but also at the date payment on the note is made can easily be avoided. For example, a corporation need only purchase its own shares for cash, then have the former shareholder loan back to the corporation the cash received. Although it is true that a court might well look at the substance rather than the form of such a transaction, there is still the possibility that such a subterfuge may succeed. Finally, postponing the date of application of the surplus and solvency tests may enable insiders to lawfully and purposefully defraud those shareholders who have surrendered their shares to the corporation in return for a promissory note or other corporate obligation. This can be accomplished by the use of the power to declare dividends in an amount equal to the available surplus, along with other perfectly legal methods of depleting surplus, thereby indictively insuring that there would never be any surplus to pay off the note.

Assuming this view is accepted, it will be necessary to expressly provide 80 in the legislation so as to avoid possible confusion. ${ }^{344}$ This can be most easily accomplished by defining "purchase" to include the giving of a promissory note or other corporation obligation in return for the shares and providing that the surplus and solvency restrictions are to apply at the time of purchase by the corporation of its own shares.

\section{Status of Reacquired Shares}

\section{(a) Special Circumstances}

Generally speaking, where a corporation purchases its own shares in one of the "special circumstances" situations-for example, to com- 
promise a debt owed by a shareholder to the corporation or to remove troublesome fractional shares-there would be no purpose served in not cancelling the shares acquired. This is especially so where the shares are purchased out of the corporation's stated capital.

\section{(b) Purchases Under a General Power to Purchase}

There are three possibilities as to the status of shares acquired by a corporation under a general power to purchase:

(1) Cancellation: the shares are cancelled completely; both issued and authorized share capital are accordingly reduced to the extent of the purchase;

(2) Retirement: the shares are restored to the status of authorized but unissued shares (the Canadian "treasury shares");

(3) No Change: the American "treasury stock" position where the shares remain as issued or outstanding shares of the corporation.

Troublesome questions of corporate law, finance and accounting arise when considering the status of reacquired shares. The general rule at American common law was that a corporation had the option either to retire reacquired shares and therby restore them to the status of authorized but unissued shares, or to treat them as "treasury stock", that is, treat them as still being issued and outstanding and subject to resale by the corporation. Professor Ballantine explains the anomaly that arises out of this latter treatment: 345

Treasury shares are indeed a masterpiece of legal magic, the creation of something out of nothing. They are not outstanding because the obligator has become the owner of the 'obligation' as in the case of reacquired bonds.

As Hills has well said: ${ }^{346}$

Can a corporation have 'ownership' in itself? Can it possess 'legal rights and powers' or 'legal property' or 'property' derived solely from itself. Corporation law holds it cannot. Treasury shares do not have voting rights, divi-end rights or distribution rights on liquidation, so what rights, if any, remain? Perhaps the 'right' of the corporation to reissue its treasury shares for a valuable consideration if its charter law permits-but that is a mere incident of incorporation which is applicable to unissued as well as issued shares. Treasury shares are not a corporate 'asset' and cannot be considered as an asset in computing net assets or surplus available for dividends or share purchases.

The only difference between reacquired shares held "in the treasury" and those which have been retired is that the first may be resold by the corporation for what they will bring on the market, while the retired shares have disappeared and it becomes a question of original issue at par. Treasury shares carry no voting rights or rights as to dividends or distributions. Their existence as issued shares is a pure fiction, a figure of speech to explain certain special rules and privileges as to their reissue. A share of stock is simply a unit of interest in the corporate enterprise arising from a contract. When the holder of a share surrenders his rights to the corporation it is obvious that the contract is in reality terminated. In cases where the vote or assent of a majority of the shareholders is required or a given proportion of the shares is spoken of, it must be understood to mean shares which are issued and outstanding and which may be voted.

The truth is that "treasury stock" is merely authorized stock which may be reissued as fully paid, without some of the restrictions upon an

ses Ballantine, The Curious Fiction of Treasury Shares (1946) 34 Calif. L. Rev. 536 at 537.538. 
original issue of shares as to consideration and as to pre-emptive rights, if any. While often treated by accountants as an asset, such treatment is for record purposes only, not to evaluate the "assets". It no more represents a present asset than authorized but unissued shares, being merely the opportunity to acquire new assets if anyone wishes to buy the shares. If the company becomes insolvent, no such opportunity will arise and the treasury stock will represent nothing of value to the creditor.

Even assuming that reacquired shares when treated as remaining issued and outstanding do not carry voting or dividend rights, this status can still lead to much abuse. 347 For example, the reacquired shares can be resold by the corporation without having to comply with the formalities of an original issue such as prospectus requirements, allotment requirements (such as issue at par value or more) or preemptive rights, if any, in its articles of association. Secondly, the reacquired shares can be used to facilitate operations by a corporation and its management in speculating in its own shares and to enable the corporation's balance sheet to display a fictitious surplus so as to allow it to get around limitations upon dividends and upon the further purchase of its own shares. ${ }^{348}$ Thirdly, the issue of all the fully paid stock of a new corporation has often been made to a promoter in return for services rendered, so as to water the corporation's stock, and then a large part of these fully paid shares donated back to the corporation for subsequent resale at a discount.

Clearly the possibility of abuse will be greatly reduced if all the reacquired shares are treated as automatically restored to the status of authorized but unissued shares. The New Brunswick reformers have adopted this position and explain: $:^{349}$

The final problem is to determine the status of any shares that are repurchased by the
corporation. . . The Federal Draft Act provides that all such shares would
automatically return to the status of authorized but unissued shares. This avoids many
problems created by providing for "treasury shares", as used in the United States, and
this was the reason why the Dickerson Committee recommended the provision. In
reference to this provision, Iacobucci, in his commentary on the Draft Act, stated that
"this makes abundant sense, since by this simple provision, some very nasty problems
are eliminated; accounting problems relating to the purchase, especially those dealing
with presenting the "surplus" arising in the resale of such shares; problems regarding
the dividend or voting rights of reacquired shares; and problems concerning voting
and stock market manipulation".350 We are in comple agreement that allowing
treasury shares would create unnecessary problems, and it is therefore recommended
that all shares repurchased shall automatically return to the status of authorized but
unissued shares.

10. Accounting Procedure

Professor Katz outlines the relationship and problems that arise in respect of accounting procedures and a corporation's purchase of its own shares: ${ }^{352}$

316 Hills, Federal Taxation v. Corporation Law (1937) 12 Wisconsin L. Rev. 280 at 299.

347 See, generally, Ballantine, supra, n. 7 at 616-618.

346 This potential abuse has been remedied, however, by most American statutes requiring the designation of "restricted surplus" to the extent of an outstanding purchase from which no dividends or further purchases may be made.

36) Supra, n. 61 at 92.

350 Iacobucci, Shareholders Under the Draft Canada Business Corporations Act (1973) 19 McGill L.J. 246 at 252.

as Iacobucci, supra, $n .51$ at 123 agreed in his later report "We favour the federal approach because it eliminates the need for sections stipulating that purchased shares carry no right to vote or receive dividends while held by the corporation and also avoids the complexity of financial statement presentation relating to the accounting for purchased shares and any surplus arising on resale."

352 Katz, Accounting Problems in Corporate Distributions (1940-41) 89 U. of Penn. L. Rev. 764 at $779-780$. 
While purchases by a corporation of its own shares may not ordinarily be thought of as corporate "distributions" to shareholders, such transactions are closely related to corporate dividends and distributions of capital. These relations, furthermore, afford some of the most interesting illustrations of the interplay of accounting and law. An understanding of this interplay will be promoted by recognizing at the outset the complexity of the subject-the number of problems which are closely related and which must be viewed as a whole before the accounting treatment of any of them may be adequately considered. The following is an outline of the most important of these problems:

I. What are the limitations on the power of a corporation to buy its own shares, particularly limitations in terms of corporate capital or surplus?

II. What is the immediate effect of the purchase?

A. Does it have the effect of reducing the surplus available for dividends?

B. If the purchase price was less than the par or stated value of the shares, does the discount represent in any sense a profit or an addition to surplus?

III. What is the result of a resale of the shares?

A. Does the resale neutralize the effect of the purchase upon surplus (IIA, above) and restore its availability for dividends?

B. If the resale was at more than cost, must the difference be treated as a reduction of the earned surplus?

IV. What is the effect of a formal cancellation of the shares in compliance with the statutory procedure for this type of reduction of stated capital?

A. Does the cancellation neutralize the effect of the purchase on surplus (IIA, above) and restore its availability for dividends?

B. Where the par or stated value of the treasury shares exceeded their cost to the corporation, what is the significance of this discount when the shares are cancelled?

C. If the shares were purchased at more than their stated value, what is the effect of the cancellation?

The first problem posed by Professor Katz relating to the source of funds available for a corporate share purchase has already been dealt with earlier in this paper. Adopting the approach of requiring all shares purchased under a general purchase power to be automatically restored to the status of authorized but unissued shares further simplifies the accounting procedure.

Professor Katz's second major problem, namely recording the immediate effect of a corporate share purchase under a general power, can best be resolved by illustration. Consider the following simplified balance sheet:

\section{CORPORATION A}

Cash

$$
\$ 100,000
$$

$\overline{100,000}$
Accounts Payable Issued Capital 250 Shares

Retained Earnings (Earned Surplus)
$\$ 50,000$ 25,000 25,000 $\$ 100,000$

Assume now that Corporation A wishes to purchase 50 of its shares at $\$ 100.00$ per share. Obviously, to clearly reflect the result of this transaction, cash would be reduced as would the number of issued shares and the retained earnings figure. The result would be: 


\section{CORPORATION A}

Cash

$\$ 95,000$
$\$ 95,000$

Accounts Payable

$\$ 50,000$

Issued Capital

200 shares 25,000

Retained Earnings

$\frac{20,000}{\$ 95,000}$

The desired result is thus achieved in that the surplus available for dividends or for further corporate share purchases is reduced by the amount of the purchase. These shares would be carried at cost regardless of their par or stated value so that no problems of surplus arise on their original purchase. ${ }^{353}$

Professor Katz's third problem, namely the effect of a resale of the shares, is again best resolved by illustration. Continuing with the above balance sheet, assume now that Corporation $\mathrm{A}$ has legitimately resold the 50 shares for $\$ 6,000.00$; in other words, a "trafficking" profit of $\$ 1,000.00$ had been realized. There are three basic methods of accounting for the $\$ 6,000.00$ sale price:

(1) The first is to attribute all $\$ 6,000.00$ to the issued or stated capital account. This accounting procedure naturally flows from having restored the shares upon purchase to the status of authorized but unissued shares. Although it could be argued that this procedure results, in effect, in a capitalization of the $\$ 5,000.00$ retained earnings used to originally purchase the shares and therefore unduly prejudices the remaining shareholders of the corporation (and, of course, unduly benefits the creditors) since it has been legitimately recovered, this argument is untenable since it fails to distinguish between purchase of the shares, and their subsequent resale. The purchase by a corporation of its own shares out of retained earnings in a distribution of corporate assets (albeit inequal) is similar to that resulting from the payment of a dividend. The subsequent resale of the shares is a separate transaction distinct from their original purchase. Even if the same shares are resold to the same shareholders who sold them for the exact price at which they were purchased (so as to restore the status quo before purchase) it nonetheless detracts from the fact that this resale transaction is an issue of previously unissued shares and must therefore be treated and accounted for accordingly.

(2) The second method, flowing from the discussion above, is to attribute the $\$ 5,000.00$ to retained earnings and the $\$ 1,000.00$ "trafficking" profit to contributed surplus or some similar account. The restoration of the $\$ 5,000.00$ to retained earnings suffers from the defect outlined above. The allocation of the $\$ 1,000.00$ "trafficking" profit to a capital surplus account effectively precludes its availability for dividends or for future corporate share purchases.

(3) The third method merely varies the first by attributing the $\$ 1,000.00$ "trafficking" profit to retained earnings thereby rendering it available for dividends or for future corporate share purchases. Professor Katz ${ }^{354}$ notes that a bitter fight has raged among American accounting authorities as to the proper treatment of such a "trafficking" profit and

353 Id. at 788. See also CICA, supra, n. 283 at para. 11; Ballantine, supra, n. 14 at 618.

354 Id. at 787.788. 
that the forces opposing the treatment of this item as an addition to earned surplus appear to have won the day. At least one writer has urged further that it is anomalous to consider as capital a part, but not all, of the consideration received upon the reissuance of purchased shares. ${ }^{355}$ He considers more "logical" either the position that all of the consideration becomes a form of capital, or the position that none of it does and that the "trafficking" profit is an addition to retained earnings. It would appear, therefore, that the proper accounting procedure would be to treat the whole $\$ 6,000.00$ as being issued or stated capital or to stated capital and contributed surplus. The result would be this:

\section{CORPORATION A}

Cash

$\begin{array}{ll}\$ 101,000 & \text { Accounts Payable } \\ \text { Issued Capital } \\ 250 \text { shares } \\ \text { Contributed Surplus } \\ \text { Retained Earnings }\end{array}$

$\$ 50,000$

25,000

\section{$\$ 101,000$}

$\$ 101,000$

\section{The CICA agree with this result in stating:356}

Where a company acquires its own shares and subsequently resells them, no part of the proceeds should be taken into income.

Where a company resells shares that it has acquired, any excess of the proceeds over cost should be credited to contributed surplus; and deficiency should be charged to contributed surplus to the extent that a previous net excess from resale or cancellation of shares of the same class is included therein, otherwise to retained earnings.

On the question of the availability of this "trafficking" profit for dividends or for future corporate share purchases, Professor Gower in his Ghana Code separated these two purposes by account for a corporate share purchase as follows:357

63.1(1) When a company first redeems or purchases any of its shares (otherwise than on a redemption of redeemable preference shares out of the proceeds of a fresh issue of shares in accordance with paragraph (b) of subsection (1) of section 60 of this Code) it shall open an account, to be known as the 'share deals account' and shall credit thereto a sum not less than the amount to be expended on such redemption or purchase by transferring such sum from income surplus, as defined in section 70 of this Code.

(2) To such share deals account shall be debited all sums which the company shall from time to time expend on the redemption or purchase of any of its shares (otherwise than on a redemption if redeemable preference shares out of the proceeds of a fresh issue of shares in accordance with the said paragraph (b) of subsection (1) of section 60 of this Code), and to such account shall be credited the net price or the value of the consideration received by the company on the re-issue of any of its treasury shares.

(3) If at any time the total amount to be debited to the share deals account under subseciton (2) of this section would exceed the amount credited thereto in accordance with subsections (1) and (2) of this section, an amount equal to such excess shall be transferred to the credit of such account from income surplus, as defined in section $\mathbf{7 0}$ of this Code, and no purchase or redemption (otherwise than a redemption of redeemable preference shares out of the proceeds of a fresh issue of shares in

3ss Husband, Accounting Postulates: An Analysis of the Tentative Statement of Accounting Principles (1937) 12 Accounting Review 386 at 398-399.

sse Supra, n. 283, paras. .19 and .20 .

357 Supra, n. 64 at 8. 63. 
accordance with the said paragraph (b) of subsection (1) of section 60 of this Code) shall be made by the company unless its income surplus is sufficient to enable such transfer to be made.

(4) No amount shall be debited or credited to the share deals account, otherwise than in accordance with the foregoing subsections of this section, except on a transfer to stated capital in accordance with section 66 of this Code or under an order of the Court under section 77 or 231 of this Code.

\section{His commentary explains its effect: 358}

The problem of accounting for transactions in treasury shares is one which has given rise to much disagreement in the U.S.A. After lengthy discussion with experts I think that section 63 is the simplest and neatest answer. In effect this provides that all such transactions must be shown in a separate account. This account must not be allowed to fall into debit and must be fed from surplus which would otherwise be available for dividend in order to prevent this. A credit balance on the account constitutes part of the surplus of the company . . . which may be frozen by transfer to stated capital . . . but not of the company's income surplus available for dividend. The result is to ensure that shares are only purchased out of such surplus or out of the profit on previous dealings and that any profit on dealings in them is not available for dividend [emphasis added]. Indeed, it goes somewhat further. Once a company has transferred from surplus available for dividend to share deals account it cannot re-transfer it except by an increase of stated capital. Hence not only is the profit on deals excluded from the dividend fund but also is anything transferred to feed the account. In practice, however, it should only be the initial transfer, required under section 63(1), which should amount to any substantial transfer from surplus.

Finally, Professor Katz's fourth problem, namely the relationship of the formal reduction of capital provisions where the corporation desires to cancel and not merely retire the purchased shares, is easily dealt with, Since the shares upon purchase are automatically restored to the status of authorized but unissued shares, their subsequent formal cancellation merely results in a reduction of authorized capital and no further additional balance sheet entries are required.

\section{Additional Considerations}

There are certain additional considerations that arise when dealing with a corporation's purchase of its own shares that relate to broader topics in corporation law. There are considerations of disclosure, insider trading and market manipulation. These topics, by their very nature, warrant study in a much broader context than that of a corporation's purchase of its own shares and it would be beyond the scope of this study to do more than point out the issues they give rise to in relation to corporate share purchases.

It is generally agreed that where a corporation is empowered to purchase its own shares it must be classed as an "insider" so as to bring it within the disclosure requirement and potential liability of the insider trading provisions of the corporation statute ${ }^{359}$ Disclosure requirements can arise either under the insider trading provisions of the corporate statute $^{360}$ or, for listed corporations, the securities legislation ${ }^{361}$ or the take-over provisions of the securities legislation. ${ }^{362}$ Section $80(\mathrm{~g})$ of the Securities Act defines a "take-over bid" as "an offer, other than an exempt offer, made to shareholders the last address of any of whom as shown on the books of the offeree company is in Alberta to purchase

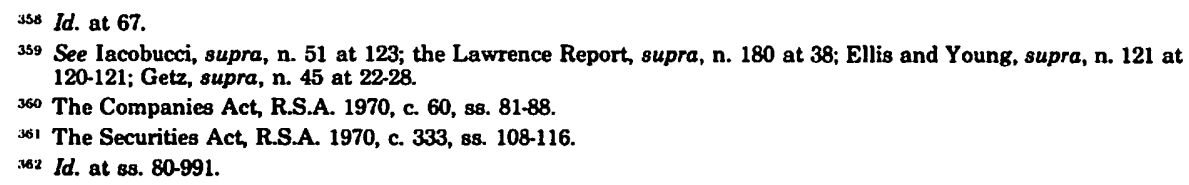


such number of equity shares of a company that, together with the offeror's presently-owned shares, will in the aggregate exceed 20 per cent of the outstanding equity shares of the company." If, therefore, the corporation offers to purchase more than twenty percent of the outstanding equity shares, compliance with the Securities Act would be necessary. The most notable consequence of this necessity is that the offer to purchase will have to comply with section $85(1)$ of the Securities Act, which requires that "a take-over bid circular shall form part of or accompany a take-over bid." The detailed contents of a take-over bid circular are set out in section 90 of the Act.

A corporate share purchase by a listed or public corporation that does not constitute a take-over bid as defined in the Securities Act will not be subject to any direct statutory obligation of disclosure to shareholders with respect to the transaction, except such as may be called for in order to avoid insider trading liability under the Companies Act or the Securities Act. Professor Getz ${ }^{363}$ notes that in British Columbia the Securities Commission has, however, imposed certain reporting requirements of its own, quite apart from the statutory scheme of disclosure. The Commission points out that: ${ }^{364}$

... [it] is concerned with the public's need and the shareholder's need and right to know first that the volume and price of the purchasing company's shares, as reflected in the published volume and prices of the Vancouver Stock Exchange or the over-thecounter market, could be affected by a purchase program implemented by the company itself, and second that the company of which they are shareholders is purchasing its outstanding shares.

In the light of this concern, the Commission has ruled that any British Columbia reporting company intending to purchase some of its own shares must give the Commission and, when it is listed, the Exchange, seven clear days advance notice of its intention, and supply certain specified information about the proposed purchase. ${ }^{365}$

A private corporation's purchase of its own shares would only be subject to the disclosure requirements of the insider trading provisions of the Companies Act.

In any event, disclosure can be of two general types: prior disclosure (or disclosure before the transaction) and disclosure after-the-fact. It seems eminently reasonable to require the corporation to disclose its intentions prior to purchasing its own shares as well as reporting the results thereof since "a full disclosure of repurchase objectives and plans will enable all stockholders to reappraise the value of their shares and act accordingly." 366 An even more important consideration is what information constitutes adequate disclosure. This, in turn, involves the issues of materiality of information and its use disclosure of the corporate share purchase and also raises the question as to what extent corporations will be forced to forecast future earnings. As Iacobucci provides: ${ }^{367}$

54.3 Supra, n. 45 at 20.

:6t British Columbia Securities Commission Weekly Summary: week ending March 15, 1974.

163 Id. The required information includes the total number of securities to be purchased and the maximum limit price per share set, if any; the period over which the purchases will be made; and whether any of the shares to be purchased are beneficially held by a director, officer or insider.

366 Ellis and Young, supra, n. 121 at 62 . Israels, Corporate Purchases of its Own Shares-Are There New Overtones (1964-65). 9 Cornell Law Quarterly 620 at 621 provides "Where the general body of shareholders are the potential sellers, questions may well arise as to the adequacy of the information made available to them as the basis on which they will determine whether or not to sell."

36i Supra, n. 51 at 123. The Lawrence Report, supra, n. 180 at 38, seemed concerned only with disclosure after the fact: “Because a company's trading in its own shares can be said to be a form of 'insider trading'. the 
As is done in the other jurisdictions examined, we recommend that the corporation purchasing its own shares be treated as an insider for purposes of the rules relating to insider trading. However, we would also recommend that the corporation be required to report to its shareholders the details concerning its share purchases. We further suggest that Alberta consider requiring the corporation to describe briefly the reasons for the purchase when this can be disclosed. In our view shareholders should be given details, including reasons, to provide them with a basis for questioning the advisability of such purchases. Requiring such disclosure could also act as a salutary incentive for directors to authorize purchases only for valid and genuine purposes. However, the disclosure suggested is not without its difficulties and upon closer examination it may be impracticable to prescribe in legislation.

\section{Ellis and Young discuss disclosure from an Emerican point of view: ${ }^{368}$}

Disclosure of repurchasing involves several aspects. First, if the shares are being acquired because they are considered 'cheap,' it seems incumbent upon the corporation to disclose the basis for this judgment. On the other hand, the SEC has made clear its desire to have corporations avoid forecasts of earnings, sales, etc., which would obviously be material information if accurate. The more uncertain the information, the less it is to be considered material. The dilemma is clear when the shares appear 'cheap' in relation to long-term prospects.

As to the fact of the repurchasing itself, it has been suggested by some that the selling stockholder should be advised that the buyer of his specific shares is the corporation itself. This seems absurd provided the corporation has revealed the repurchasing program as a whole which is far more important as a guide to investor decisions than whether the corporation happens to be buying any specific shares. In line with this view is the following informed observation:

'I am not persuaded by the argument that the selling shareholder would not have sold, at least without further investigation, had he known the identity of the corporate purchaser. Sales conducted on an exchange or over-the-counter are generally initiated by the seller without consideration of the identity of the purchaser. The seller wants to sell and it is probably impossible to isolate completely his motives. At present, sellers realize that they may be selling to officers, directors or others who have superior knowledge and this has not dissuaded them from going forward with the transaction ... Section 16(b) of the Securities Exchange Act of 1934 is designed to regulate such transactions, but not outlaw them. The market place where the shares are sold is designed in part to eliminate questions of identity; its basic function is to provide a free market place so that shares may be sold quickly and inexpensively. Indeed, I think that the free alienation of shares is an important factor which must be continually re-emphasized in dealing with the problems surrounding Rule 10 (b)5. Imposing a requirement that the corporation must identify itself would limit the beneficial results which flow from such markets and the corresponding gain, if any, to investors would be too minimal to warrant the adoption of such a standard. True, the impersonal nature of such transactions should not be used as a mask to permit insiders to reap large profits on the basis of inside knowledge, but the disclosure requirements which have been previously discussed amply protect investors. ${ }^{369}$

In view of the trend toward increased ficuciary responsibility on the part of the corporation, it seems clear to the authors, who have followed such practices closely for several years, that corporations are increasingly taking care to report regularly to stockholders their actual and intended repurchases. Such reports are made in annual reports and other regular reports to stockholders, and cover both future plans and past achievements, with large or unusual repurchases reported through special releases.

Professor Getz discusses the considerations involved in market purchases and manipulation most adequately: ${ }^{370}$

The concept of the free market in publicly traded securities has long been embodied in Anglo-Canadian law. As McLennan J.A. remarked in $R$. v. MacMillan: ${ }^{371}$

Committee further recommends that [the Ontario Act] be amended to require the disclosure, in a balance sheet or a note thereto, of the dates of purchase and sale by the company in the year of any equity shares carrying voting rights under all circumstances and the prices at which such purchases and sales were made."

${ }^{368}$ Supra, n. 121 at 121-122. An excellent discussion of the question of adequate disclosure is also found in Getz, supra, n. 45 at $22-28$.

369 Kennedy, Transactions by a Corporation in its Own Shares (1964) Bus. Law. 321 at 329.

370 Supra, n. 45 at 32.37 .

37 (1968) 66 D.L.R. (2d) 680 (Ont. C.A.) at 686. 
'... to the extent that the economy of the country is based upon enterprises requiring capital and therefore the free trading in securities it is of the utmost importance that public confidence be maintained in the integrity of trading in the stock exchanges. . . .

And further:

It has been suggested above that failure to disclose the identity of the purchaser and the reasons for repurchase may constitute a basis for insider trading liability in favour of the vendor shareholder. It seems likely, however, that such liability can be asserted only by shareholders who sell to the corporation, and not by those, who, albeit suffering from the same defects of knowledge as the latter, sell their shares at the same time and price to a different purchaser. Nor will those non-shareholders be protected who, seeing the upward movement of the market price, decide to buy in. ${ }^{372}$

Concern about manipulation of this kind is frequently answered by the assertion that the problem is adequately dealt with by the Criminal Code. Reference is made, in particular, to what is now section 340, which provides:

Every one who, through the facility of a stock exchange, curb market or other market with intent to create a false or misleading appearance with respect to the market price of a security,

(a) effects a transaction in the security that involves no change in the beneficial ownership thereof,

(b) enters an order for the purchase of the security, knowing that an order of substantially the same size at substantially the same time and at substantially the same price for the sale of the security has been or will be entered by or for the same or different persons, or

(c) enters an order for the sale of the security, knowing that an order of substantially the same size at substantially the same time and at substantially the same price for the purchase of the security has been or will be entered by or for the same or different persons,

is guilty of an indictable offence and is liable to imprisonment for five years.

Now, if a plan of market manipulation involves the use of wash sales and matched orders, as may frequently be the case, then doubtless section 340 might be resorted to. But if, as in the Pennzoil case, the transactions are real, and do not involve a change in beneficial ownership of the securities, section 340 would be of little help.

The only other provision that might be relevant is section $338(2)$ of the Criminal Code, which provides:

Everyone who, by deceit, falsehood or other fraudulent means, whether or not it is a false pretence within the meaning of this Act, with intent to defraud, affects the public market price of stocks, shares, merchandise or anything that is offered for sale to the public, is guilty of an indictable offence and is liable to imprisonment for ten years.

This provision has obvious limitations as applied to a scheme such as that involved in the Pennzoil case. These are concisely described in the following comment : $^{374}$

It is questionable, for example, whether mere buying and selling, even when engaged in with the clear purpose of profiting from the appearance of market activity thus created, would, at least in the absence of a conspiracy, fall within [section 338(2)]. In such a case, an 'intent to defraud' might be provable, but it is doubtful that the method of manipulation employed constitutes 'deceit, falsehood or other fraudulent means' within the meaning of the section.

It is by no means clear, therefore, that the provisions of the Criminal Code would be effective to deal with manipulative practices of the kind under discussion. ${ }^{375}$

Jrz This is because the wording of the insider trading liability provisions seems to import a "privity" requirement. The alternative, which might provide persons such as those mentioned in the text with some remedy, would be to impress what is, in effect, an insurer's liability provision, upon all insiders. It is almost impossible to imagine a Canadian court interpreting the legislation in this way.

s73 Davis v. Pennzoil Co. (1969) 264 A. (2d) 597 (Penn. S.C.); see supra, n. 175.

374 J. P. Williamson, Securities Regulation in Canada (1960), Supplement (1966) 197. Compare $R$. v. Electrical Contractors Association of Ontario and Dent (1961) 27 D.L.R. 193 (Ont. C.A.) with $R$. v. McDonnell [1966] 1 All E.R. 193 (Bristol Assizes). See generally, Leigh, Criminal Liability of Corporations in English Law (1969) $53-4$.

${ }^{375}$ See, R. v. Littler (1974) 13 C.C.C. 530 (Que. Crt. S.P.), where the accused was convicted under the general fraud provision (section $338(1)$ ) for activity which, in British Columbia, could well have given rise to liability under the insider trading provisions. In the course of his judgment. Loranger $J$. held at 550 that the persons from whom the accused had purchased shares in the open market without disclosing certain material 
An instructive contrast is provided by section $9(a)(2)$ of the Securities Exchange Act of 1934. This makes it unlawful "to effect, alone or with one or more other persons, a series of transactions in any security registered on a national securities exchange creating actual or apparent active trading in such security, or raising or depressing the price of such security, for the purpose of inducing the purchase or sale of such security by others." The provision has been described by the S.E.C. as "the very heart of the act", ${ }^{376}$ and is clearly aimed, inter alia, at pooling and cornering operations entered into with a manipulative intent. ${ }^{377}$

There is no comparable provision in Canadian law. A number of the Stock Exchanges-those in Vancouver and Toronto, for example-have trading rules in almost identical terms. Thus, Vancouver Stock Exchange Rule 385.1 prohibits any seatholder, director, officer, or employee of a seatholder from using or knowingly participating in any manipulative or deceptive method of trading which creates or may create a false or misleading appearance of trading activity or an artificial price for any liable security. Rule 385.2(e) deems "effecting, alone or with one or more persons, a series of transactions in any such security, for the purpose of inducing the purchase or sale of such a security, which creates actual or apparent trading in such security or raises or depresses the price of such security" to be a manipulative or deceptive method of trading, unless with a view to stabilizing the market. In the result, this sort of behaviour is controlled through surveillance and disciplinary functions exercised by the Exchanges over their members, ${ }^{378}$ coupled with the inside reporting requirements and the advance disclosure policy of the Commission and the Exchange. The latter, it should be noted, applies only to "repurchase programmes". It remains to be seen how effective these constraints will be upon a company management determined to manipulate. ${ }^{379}$

\section{Sanctions for Improper Corporate Share Purchases}

Merely restricting general purchases of a corporation's own shares to instances where both the surplus and solvency tests are met, without more, is insufficient to curb potential abuse. There must also be imposed some form of remedial sanction enforceable by the corporation itself (or a receiver thereof), or by its remaining and future shareholders or by its existing and subsequent creditors against the directors, and perhaps, the selling shareholders. The sanction should be designed to restore as

information, were defrauded, and that they "represented the public as a whole. It was the public in general which was defrauded of the real value of these shares."

176 Quoted in Loss, 3 Securities Regulation, (2nd ed. 1961) 1549.

w7 Id. Ellis and Young, supra, n. 121 at $122-123$ provide: "Manipulation is clearly prohibited. Misleading and/or false information released with the intention of affecting the market is prohibited under section $10(b) 5$. Section $10(b) 6$ prohibits a corporation from repurchasing its common stock during a distribution of its shares which in turn raises the question as to what constitutes a distribution, a problem that artful attorneys wil solve in time." Kessler, supra, n. 120 at 680 provides: "Market rigging is already restricted by the rules of the SEC. Limited corporate purchases within federal and stock exchange regulations may be desirable, Still, a general exception for corporate speculation in its own shares is very dangerous. Management's activities should be directed to the improvement of the corporation's legitimate business, and any general exception for such speculation would, if not inevitably result in a breach of director's duties and market rigging. at least constitute an undesirable distraction from their obligation to further the corporation's business."

.jin For generally critical comments on the role of the Stock Exchanges, see Report of the Ontario Royal Commission to Investigate Trading in the Shares of Windfall Oils and Mines Ltd. (1965) 104-17. But see Report of the (Porter) Royal Commission on Banking and Finance (1964) 331-55.

siy The Porter Commission, supra, n. 378 at 354 remarked that "little is known about the extent of market manipulations in Canada . . . although we have the impression that such activities are carried out by only a small minority of securities dealers." But see Shaffer, The Stock Promotion Business (1967). Finally, note the comments of Farano, supra, n. 282 at 44-45: "There is no requirement for prior publicity of open market purchases and it may be possible that this could lead to abusive tactics such as discrimination against minority shareholders and various other forms of discrimination.

It is possible that controlling shareholders may benefit form the new purchase provisions where the corporation pays them more for their shares than other shareholders could obtain in similar circumstances or if the corporation should acquire shares from minority shareholders at unreasonably low prices.

Problems may arise in connection with the use of corporate purchases of shares to retain control in situations involving take-over bids. Directors and senior officers may be tempted to use the facilities of the corporation to assiat them to increase their control position in a take-over situation. It may be that the argument that the use of such facilities was in the best interests of the corporation could prevail depending on the circumstances, but the burden of justifying such action would rest firmly upon the directors. Merely to solidify their control position would not be sufficient justification.

Without adequate regulation of self-serving transactions on the open market it may be relatively simple to 'rig' prices artificially where the corporation makes the last purchase on the day's trading and also the first trade at the opening of trading on the following day. There appears to be far too much latitude here for the unscrupulous. The practice in the U.S. is to regulate strictly open market trading of this sort." 
nearly as possible the financial status quo of the corporation before an improper (or more appropriately an "illegal") corporate share purchase took place. In most cases a share purchase under a general power of purchase that improperly impairs capital and/or renders the corporation insolvent will be impugned by a receiver or trustee in bankruptcy of the corporation.

Clearly a corporate share purchase made in violation of statutory restrictions is illegal and therefore void. Accordingly, it would seem appropriate that the selling shareholder should be required to account for the purchase price he received. However, this simple view is not without complications. For example, is it material that the selling shareholder did not know that the purchase was improper or even that the corporation was the purchaser? ${ }^{380}$ Professor Dodd comments: ${ }^{381}$

A quite different question is presented by cases in which the purchase is completed by the payment of cash at a time when the corporation, although solvent, has no surplus. If the shareholder knew of the lack of surplus, he has knowingly participated in an unlawful act and he should be under a duty to refund the purchase price, at suit of the corporation or of its receiver or trustee in bankruptcy. ${ }^{382}$ But what of the innocent shareholder-participant in such a transaction? Should the latter's ignorance of the corporation's financial condition, or his honest and perhaps reasonable belief in the existance of an adequate surplus, be a defense to an action subsequently brought by the corporation, or by a representative of its creditors to compel him to refund the amount which he has received? . . .

Decisions holding that an innocent recipient of unlawful dividends need not refund them if the corporation was solvent when the dividend was paid are clearly distinguishable. The shareholder is a mere passive recipient of dividends; he is an active participant in a sale of his shares. Receipt of dividends is an ordinary transaction, occurring at frequent intervals. Purchase, even though generally valid if a surplus does exist, is an unusual transaction, a single instance unlikely to recur so far as the individual shareholder is concerned. The legal power of successful corporations to declare dividends is essential to the proper functioning of modern capitalism and one who receives a dividend from a supposedly successful corporation assumes that he is merely reaping the normal reward which our economic system holds out and must hold out as an inducement to those who supply business with its essential funds. The seller of shares to a supposedly prosperous corporation, on the other hand, is taking part in a transaction which would, even if the supposed surplus existed, be one which the law may be regarded as tolerating rather than encouraging.

In fairness not only to creditors but also to other shareholders, who are likely to be adversely affected by purchases which impair capital, the selling shareholder should not be permitted to receive corporate assets in payment, except subject to a duty to disgorge if it later turns out that the sale was unlawful. On the other hand, one who reasonably believes that the purchaser of his shares is someone other than the corporation should not be compelled to refund money, which unknown to him came from the corporation, even though the payment impaired its capital.

The Lawrence Report ${ }^{383}$ agreed that violation of the statutory restrictions on the right to purchase should give rise to liability on the part of the shareholders receiving payment of purchase money for shares. It does not follow, however, that the selling shareholder should, at his instance, be entitled to rescind the transaction on the basis of a

\footnotetext{
:waker and Cary, Corporations: Cases and Materials (3d ed.), (1959) at 1426.

int Supra, n. 67 at 710-711.

142 The purchase out of capital in violation of statute is a misuse of corporate funds and a wrong to the other shareholders and not merely to the creditors. The California Code limits liability to one "who sells such shares knowing that the corporation is the purchaser with knowledge of facts indicating the impropriety of such purchase", and imposes it only if the corporation is adjudged insolvent or bankrupt in any proceeding brought within a year. The Maryland statute, which limits purchases to those out of surplus and provides that, if the purchase is in violation of the Act, the recipient of payment shall be liable to refund it so far as needed to pay corporate debts existing at the time of payment.

sn:s Supra, n. 180 at 38.
} 
rule intended for the protection of the corporation and its creditors. The selling shareholder has suffered no wrong. ${ }^{384}$

What of the liability of directors who consent to or authorize an improper share purchase? Leblovic provides: ${ }^{385}$

There is little doubt that the key individuals in a stock purchase by the company are the directors. They control the internal management of the company and thus make the related decision as to when it would be in the best interests of the company, the shareholders and the creditors to take such a step. But it would also be possible, as noted above, for a director to utilize his position to benefit himslef at the expense of the company and/or third parties dealing with the company. It is to this end that the restrictions and penalties upon the directorate must clearly be sufficiently comprehensive to deter such actions.

From the present common law we arrive at the position that the director is in an ubberimae fidei fiduciary relationship with the company and therefore is accountable to it for any profit or gain realized through dealing with corporate assets or by reason of his position. ${ }^{385}$ a But it is quite clear that no such comparable duty is owed to the shareholder or to any other outsider dealing with the company.386 This position presents a dichotomous situation with regard to any stock redemption transactions that are instituted.

Firstly, in regard to the company's position, it appears that the common law fiduciary responsibility is sufficient to protect the corporate interests against a mala fides director. As noted above, the director can make no profit, direct or indirect, intentionally or unintentionally, which is related in any way to his official position. Thus in the matter of stock repurchase the director must in no way prejudice the interests of the company or he will be held personally responsible for any such actions. But in the stock redemption, the shareholder is equally a party to the transaction and yet one notes that he has absolutely no protection from the prejudicial acts of the directorate. It is by no means necessary for the interests of the company to be in accord with the interests of the shareholder and in fact it would seem compatible with acting in the best interests of the company for the director to prejudice the position of the shareholder.

Thus it seems necessary for Ontario to create an extended fiduciary relationship between the directorate and the interested outsider. The old theory of the director being an agent only of the company and this owing no duty to the shareholder 387 is possibly dangerous and, at best, medieval in this modern business society.

The United States has long recognized this extended responsibility of the direcotrate and has by common law, 388 and by statute created a direct fiduciary duty in the director to the company's shareholders, thus requiring him to balance the interests of both the company and the shareholder when dealing in a stock redemption transaction.

Closely connected to the fiduciary duty of the director is the question of the standard of care to which he will be held in his day-to-day actions. In this respect at common law adequate protection is lacking both to the company and to the shareholder. The standard of skill and diligence required of a director is not at the high level of the fiduciary but is extremely lax, comparable in many respects to the duty of care applicable in common negligence actions. It would be quite conceivable under this standard for a bona fide, but bungling directorate to wipe out a company and $/$ or its shareholders in a stock purchase and be completely exonerated from any liability. It would seem that in the highly complicated procedures connected to the stock purchase transaction good sense would require a greater level of diligence than exists today under the common law.

Unlike the fiduciary situation, seen above, recent statutory changes have been introduced to relieve somewhat the dsiabilities of the common law position ...

sw Ballantine, supra, n. 7 at 623. Some American jurisdictions have, however, held the opposite in Tiedje v. Aluminum Paper Milling Co. (1956) $46 \mathrm{Cal}$. (2d) 450, a selling shareholder was entitled to restoration of his shares on the ground that the purchase by the corporation was in violation of the California statute ("should not be allowed except out of earned surplus").

34s Supra, n. 4 at 68.70 .

uss. Sun Trust Co. v. Begin [1937] 2 Ch. 421.

ass Percival v. Wright [1902] 2 Ch. 421.

as7 In Re City Equitable Fire Insurance Co. Ltd. [1925] Ch. 407.

ass Pearlman v. Feldman 219 F. (2d) 173. 
[establishing] a statutory standard requiring a director to act in good faith, exercising the care, diligence and skill of a reasonable director in a similar situation.

But once again the position of the individual shareholder is completely ignored. This duty extends only to the best interests of the corporation and thus leaves the standard of care in relation to the shareholder at the old common-law level. The inclusion of a derivative right of suit for the shareholder is only to permit him to bring an action on behalf of the company when the company will not do so on its own, but no new rights are given to any suit where the shareholder himself is prejudiced by the actions of the director.

Thus, in summary, it appears to this writer that the corporation is now amply protected from any illegal or irresponsible action by the directorate, but it is equally apparent that in both these vital areas the standards applicable to the interested third party are insufficient if we are to extend the discretionary powers of the directors by the introduction of stock-redemption legislation.

It seems, however, that if the remedy sought is repayment of the purchase price to the corporation by the selling shareholder or restitution by the assenting directors, the remaining shareholders are adequately protected. Thus, many statutes impose joint and several liability to the corporations on the directors who authorize an improper corporate share purchase with such liability being for the amount of consideration paid for the shares which was in excess of the maximum amount which could have been paid therefore without violating the provisions of the statute. ${ }^{389}$ The principle applicable is the same as that for any unauthorized distribution of corporate assets.

A few jurisdictions have gone a step further in attempting to enforce statutory safeguards provided in corporate share purchase legislation by rendering conduct in violation of its provisions a criminal of quasicriminal misdemeanour. ${ }^{391}$ Such imposition is apparently based on experience which has shown that civil redress is not sufficient to secure observance of the law. ${ }^{392}$ As one American writer suggests: "The threat of indictment, rather than actual prosecution, can be used effectively, as the current federal anti-trust campaign demonstrates." 393 Although perhaps not that common, ${ }^{394}$ the imposition of potential criminal or quasi-criminal liability may well have a required deterrent effect otherwise absent from the imposition of civil liability alone when one considers the possibility of directors being indemnified under an insurance policy for their impropriety.

Whether the statute imposes civil liability alone on the directors or couples with it a form of criminal or quasi-criminal liability, it is necessary to provide some type of exoneration for the dissenting director in the form of defenses to civil liability where an improper corporate share purchase has taken place. In addition to the provision allowing the direcors to apply to a court for a determination of the solvency. of the corporation discussed earlier, defenses to liability should be available

\footnotetext{
369 Bergmann, supra, n. 177 at 364.

$3 \%$ Getz, supra, n. 45 at 11-12, provides with respect to the B.C. Act: "When a company is, or would be rendered insolvent in this sense, it may not repurchase its issued shares, and, if it does, the directors of the company who vote for, or consent to a resolution authorizing the repurchase, are jointly and severally liable to the company to make good any loss or damage suffered by it as a result of the transaction. It may be noted, in passing, that a similar liability is imposed upon directors who authorize a dividend payment in comparable circumstances." See also Baler and Cary, supra, n. 380 at 1427.

sol For example, under the New York Penal Law it is a misdemeanor for a director "to apply any portion of the funds of such corporation, except surplus, directly or indirectly, to the purchase of its own stock, except as provided or permitted by law."

392 Nussbaum, supra, n. 66 at $991-992$

s93 Pollis, supra, n. 131 at 428.

sw4 See Tanner. The Illinois Business Corporation Act-Purchase by a Corporation of its Own SharesAccounting and Legal Problems (1941-42) 20 Chicago-Kent L. Rev. 115.
} 
where: (1) a director has dissented in writing to the purchase, or (2) has acted in good faith and in reliance upon the balance sheet of the corporation as prepared by a recognized auditor or chartered accountant. 395

\section{SUMMARY396}

A corporation's purchase of its own shares is a form or method of distributing corporate assets similar to, but distinguishable in principle from both redemption of preferred or special shares and the payment of dividends. Further, a corporate share purchase is, in effect, the operation of the capital market in reverse to the extent that its primary function is to provide a source of corporate investment capital.

The origin and development of the English and Canadian position is one from strict prohibition to modification by both the common law to some extent, and by statute realization of the need for flexibility in arranging modern corporate affairs. More recently in some provinces of Canada the common law prohibition has been entirely abolished by statute. The American common law developed for the most part by allowing such corporate share purchases and this power is now granted and regulated by legislation in every state.

The power of a corporation to purchase its own shares can be a valuable corporate tool and can be exercised for many important business purposes. For example, there are circumstances where such a power can be exercised for the advantage of both creditors and shareholders, such as to collect or compromise an indebtedness due to the corporation, to purchase the shares of a dissenting shareholder under their appraisal rights, to eliminate fractional shares or, perhaps, to purchase shares pursuant to an employee share ownership scheme. Furthermore, a general power to purchase can be very useful to both the listed or public and the private or close corporation. For example, employee share ownership and benefit schemes, mergers and acquisitions, corporate reorganization and investment, and elimination of small shareholdings can all be more easily facilitated by the existence of a general corporate purchase power. More specifically with respect to the private or close corporation, a corporate share purchase can be used to smoothly transfer control, or to provide the necessary and often otherwise unavailable funds to buy the shares of a deceased, retiring or dissenting shareholder.

The power of a corporation to purchase its own shares can, however, also be used for improper purposes and can give rise to abuse. There are the nebulous reasons such as repurchase clauses contained in original share subscription agreements, maintenance and manipulation of both the market price of the corporation's shares and control within the corporation and the more blatant possible abuses that could operate to the prejudice of creditors, shareholders and the general investing public alike. This possibility of abuse provides the strongest reason for denying

19. Hornstein, supra, n. 17 at 624 provides: "Directors would be wise to have a financial statement prepared as of a date shortly prior to the reacquisition. This precaution is not conclusive, however, since the court is not bound by the corporation's books." Tanner, supra, $n$. 394 at 136 adds as a possible defence reliance in good faith upon the book value of the assets. Hartmann and Wilson, supra, $n$. 343 at 738 add reliance in good faith on the written opinion of counsel to the corporation.

.y+ The original Report from which the text of this paper has been taken also contained an exhaustive review of the leading American and recent Canadian legislation dealing with a corporation's purchase of its own shares. However, for the sake of brevity, this portion of the Report has not been included. Readers should consult the authorities referred to throughout this paper for such legislative analyses. 
the existence of a corporate share purchase power except in those limited special circumstances where the potential for abuse is minimal. However, the other side of this argument is that the rationale for the common law prohibition is outdated (since it is known that corporate share capital is low and not inviolate) and is unduly restrictive on internal corporate functioning. Further, such a power can be introduced with adequate statutory safeguards to properly reflect the balance between the conflicting interests of ensuring corporate flexibility and yet providing protection for creditors, shareholders and the general investing public. Such safeguards can include the requirement of shareholder authorization of the initial existence of the power, the restriction of the funds available for purchase to earned surplus or retained earnings of the corporation, the imposition of solvency and liquidity restrictions, and of directorate and selling shareholder liability for purchases in contravention of the statutory safeguards or for purchases for improper purposes. In addition, prescribing the manner and procedure by which a corporation can carry out a purchase of its own shares, including the requirement of disclosure in the case of listed or public corporations, and requiring the reacquired shares to be automatically cancelled or restored to the status of authorized but unissued shares can to a large extent remove potential abuses. 